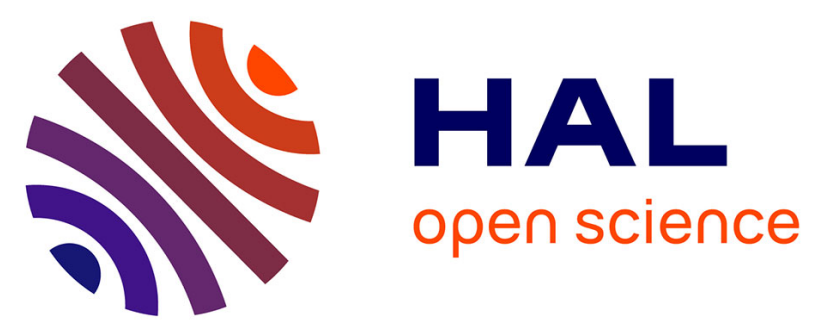

\title{
Do not forget the electrochemical characteristics of the membrane electrode assembly when designing a Proton Exchange Membrane Fuel Cell stack
}

Claude Lamy, Deborah Jones, Christophe Coutanceau, Pascal Brault, Sergueï Martemianov, Yann Bultel

\section{To cite this version:}

Claude Lamy, Deborah Jones, Christophe Coutanceau, Pascal Brault, Sergueï Martemianov, et al.. Do not forget the electrochemical characteristics of the membrane electrode assembly when designing a Proton Exchange Membrane Fuel Cell stack. Electrochimica Acta, 2011, 56, pp.10406-10423. 10.1016/j.electacta.2011.05.098 . hal-00642249

\author{
HAL Id: hal-00642249 \\ https://hal.science/hal-00642249
}

Submitted on 17 Nov 2011

HAL is a multi-disciplinary open access archive for the deposit and dissemination of scientific research documents, whether they are published or not. The documents may come from teaching and research institutions in France or abroad, or from public or private research centers.
L'archive ouverte pluridisciplinaire HAL, est destinée au dépôt et à la diffusion de documents scientifiques de niveau recherche, publiés ou non, émanant des établissements d'enseignement et de recherche français ou étrangers, des laboratoires publics ou privés. 


\title{
Do not forget the electrochemical characteristics of the Membrane-Electrode-Assembly when designing a PEMFC stack
}

\author{
Claude Lamy $^{(\mathrm{a})}$, Deborah J. Jones ${ }^{(\mathrm{b})}$, Christophe Coutanceau ${ }^{(\mathrm{c})}$, Pascal Brault ${ }^{(\mathrm{d})}$, \\ Sergueï Martemianov ${ }^{(\mathrm{e})}$ and Yann Bultel ${ }^{(\mathrm{f})}$, CNRS GDR n ${ }^{\circ} 2985$ (PACTE), \\ University of Poitiers, 40 Avenue du Recteur Pineau, 86022 Poitiers Cedex, France

\section{Introduction: Principle of Fuel Cells} \\ I.1 Fuel Cell system \\ I. 2 Proton Exchange Membrane Fuel Cell (PEMFC) \\ I.3 Components of a PEM Elementary Cell (Membrane, Catalysts, GDL) \\ I.4 Electrical characteristics of PEM Elementary Cell \\ " Effect of the membrane properties \\ ". Effect of the nature of the catalytic layer \\ * Effect of the structure of the gas diffusion layer
}

II. Experimental results obtained in the GDR PACTEII.1 Membrane Development Needs

II. 2 New preparation methods of efficient electrode catalysts

II.3 Characterization of the MEA by Electrochemical Spectroscopy (EIS)

II.4 Optimization of the Membrane-Electrode Assembly

\section{Conclusions}

(a) to whom correspondence should be sent : E-mail:<claude.lamy@ univ-poitiers.fr>

(b) Institut Charles Gerhardt, UMR 5253, CNRS-Université Montpellier 2, Aggregates, Interfaces and Energy Materials, Place Eugène Bataillon, 34095 Montpellier Cedex 5, France

(c) Laboratory of Electrocatalysis, LACCO, CNRS UMR 6503, University of Poitiers, 40 Avenue du Recteur Pineau, 86022 Poitiers Cedex, France LACCO, CNRS Poitiers

(d) GREMI, UMR6606, CNRS - Université d'Orléans, 14 rue d'Issoudun, BP6744, F-45067 ORLEANS Cedex 2

(e) Institut Pprime, UPR 3346, CNRS - Université de Poitiers; ENSMA, 40 avenue du Recteur Pineau, 86022, Poitiers, France

${ }^{(\mathrm{f})}$ Laboratoire d'Electrochimie et de Physico-chimie des Matériaux et des Interfaces, UMR CNRS-GINP-UJF 5279, 1130 rue de la piscine, BP75, 38042 Saint-Marin d'Hères, France. 


\section{ABSTRACT.}

The Membrane-Electrode-Assembly (MEA) is the key component of a PEMFC stack. Conventional MEAs are composed of catalyzed electrodes loaded with $0.1-0.4 \mathrm{mg}_{\mathrm{Pt}} \mathrm{cm}^{-2}$ pressed against a Nafion ${ }^{\circledR}$ membrane, leading to cell performance close to $0.8 \mathrm{~W} \mathrm{~cm}^{-2}$ at $0.6 \mathrm{~V}$. Due to their limited stability at high temperatures, the cost of platinum catalysts and that of proton exchange membranes, the recycling problems and material availability, the MEA components do not match the requirements for large scale development of PEMCFs at a low cost, particularly for automotive applications.

Novel approaches to medium and high temperature membranes are described in this work, and a composite polybenzimidazole-poly(vinylphosphonic) acid membrane, stable up to $190^{\circ} \mathrm{C}$, led to a power density of $0.5 \mathrm{~W} \mathrm{~cm}^{-2}$ at $160^{\circ} \mathrm{C}$ under 3 bars abs with hydrogen and air. Concerning the preparation of efficient electrocatalysts supported on a Vulcan XC72 carbon powder, the Bönnemann colloidal method and above all plasma sputtering allowed preparing bimetallic platinum-based electrocatalysts with a low Pt loading. In the case of plasma deposition of Pt nanoclusters, Pt loadings as low as $10 \mu \mathrm{g} \mathrm{cm}^{-2}$ were achieved, leading to a very high mass power density of ca. $20 \mathrm{~kW} \mathrm{~g}_{\mathrm{Pt}}{ }^{-1}$. Finally characterization of the MEA electrical properties by Electrochemical Impedance Spectroscopy (EIS) based on a theoretical model of mass and charge transport inside the active and gas diffusion layers, together with the optimization of the operating parameters (cell temperature, humidity, flow rate and pressure) allowed obtaining electrical performance greater than $1.2 \mathrm{~W} \mathrm{~cm}^{-2}$ using an homemade MEA with a rather low Pt loading. 


\section{INTRODUCTION}

Discovered in England in 1839 by Sir William Grove [1-2], the fuel cell is an electrochemical device which transforms directly the heat of combustion of a fuel (hydrogen, natural gas, methanol, ethanol, hydrocarbons, etc.) into electricity. The fuel is oxidized electrochemically at the anode, without producing any pollutants (only water and/or carbon dioxide are rejected in the atmosphere), whereas the oxidant (oxygen from the air) is reduced at the cathode. This process does not follow Carnot's theorem, so that higher energy efficiencies are expected, e.g. 40 to $50 \%$ in electrical energy, 80 to $90 \%$ in total energy (electricity + heat production).

There is now a great interest in developing different kinds of fuel cells with several applications (besides the first and until now main application in space programs) depending on their nominal power: stationary electric power plants (100 kW to $10 \mathrm{MW})$, electricity and heat production for houses and buildings ( 5 to $200 \mathrm{~kW}$ ), power train sources (20 to $200 \mathrm{~kW}$ ) for the electrical vehicle (bus, truck and individual car), auxiliary power units (1 to $100 \mathrm{~kW}$ ) for various uses (automobiles, aircrafts, space launchers, space stations, etc.) and also for portable electronic devices ( $1 \mathrm{~W}$ to $100 \mathrm{~W}$ ), such as cell phones, computers, cam recorders, etc. For the latter applications low temperature fuel cells are more convenient, particularly the Alkaline Fuel Cell (AFC) working at $80^{\circ} \mathrm{C}$ with pure hydrogen and oxygen, the Proton Exchange Membrane Fuel Cell (PEMFC), which can operate from ambient temperature to 60$80^{\circ} \mathrm{C}$ with hydrogen as the fuel, either ultra-pure hydrogen (produced e.g. by water electrolysis) or hydrogen-containing reformate gas, and the Direct Alcohol (Methanol or Ethanol) Fuel Cell (DAFC), i.e. DMFC or DEFC, which needs higher temperatures (up to $120-150^{\circ} \mathrm{C}$ ) to directly electro-oxidize methanol (ethanol). In these cases, because of the relatively low working temperature, the kinetics of the electrochemical reactions involved is rather slow. This requires the development of new electrocatalysts, in order to increase the rate of fuel oxidation and oxygen reduction [3-5].

\section{INTRODUCTION: PRINCIPLE OF FUEL CELLS [6-9]}

A fuel cell is an electrochemical power source with the advantages of both the internal combustion engine and the battery. Like a combustion engine, a fuel cell will run as long as it is fed with fuel, and like a battery, fuel cells convert chemical energy directly to electrical energy without the Carnot limitations of combustion engines. Such an electrochemical power source can reach, in theory, $100 \%$ efficiency; practical efficiencies are approximately $50 \%$ electrical and more than $90 \%$ when combining electricity and heat production. Internal combustion engines have a $40 \%$ maximum theoretical efficiency (Diesel engines) and a practical efficiency between 15 and $25 \%$. 


\section{I.1 Fuel Cell System}

A fuel cell system consists in a fuel cell stack and auxiliary equipments, which produce electrical energy (and heat) directly from the electrochemical oxidation of a fuel in an elementary electrochemical cell (Fig.1).

An elementary electrochemical cell directly converts the chemical energy of combustion in oxygen (i.e. the Gibbs energy change, $-\Delta \mathrm{G}$ ) of a given fuel (hydrogen, natural gas, hydrocarbons, kerosene, alcohols, etc.) into electricity [10-12]. Electrons liberated at the anode (negative pole of the cell) by the electro-oxidation of the fuel pass through the external circuit (producing an electrical energy, $\mathrm{W}_{\mathrm{e}}=\mathrm{nF} \mathrm{E}_{\text {cell }}$, equal to $-\Delta \mathrm{G}$, where $\mathrm{E}_{\text {cell }}$ is the cell voltage and $\mathrm{F}=96485 \mathrm{C}$ the Faraday constant) and reach the cathode (positive pole), where they reduce oxygen (from air). Inside the fuel cell the electrical current is transported by migration and diffusion of the electrolyte ions $\left(\mathrm{H}^{+}, \mathrm{OH}^{-}, \mathrm{O}^{=}, \mathrm{CO}_{3}{ }^{3}\right)$.

The electrochemical reactions involved are the electro-oxidation of hydrogen at the anode:

$$
\mathrm{H}_{2} \longrightarrow 2 \mathrm{H}^{+}+2 \mathrm{e}^{-} \quad \mathrm{E}_{1}^{\mathrm{O}}=0.000 \mathrm{~V} \text { vs. SHE }
$$

and the electro-reduction of oxygen at the cathode:

$$
\mathrm{O}_{2}+4 \mathrm{H}^{+}+4 \mathrm{e}^{-} \longrightarrow 2 \mathrm{H}_{2} \mathrm{O} \quad \mathrm{E}_{2}^{0}=1.229 \mathrm{~V} \text { vs. SHE }
$$

where $\mathrm{E}_{\mathrm{i}}^{\mathrm{o}}$ are the electrode potentials versus the Standard Hydrogen (reference) Electrode (SHE). These electrochemical reactions correspond to the combustion reaction of hydrogen in oxygen:

$$
\mathrm{H}_{2}+1 / 2 \mathrm{O}_{2} \longrightarrow \mathrm{H}_{2} \mathrm{O}
$$

with the thermodynamic data, under standard conditions (liquid water):

$$
\Delta \mathrm{G}^{\mathrm{o}}=-237 \mathrm{~kJ} \mathrm{~mol}^{-1} \text { of } \mathrm{H}_{2} ; \Delta \mathrm{H}^{\mathrm{o}}=-286 \mathrm{~kJ} \mathrm{~mol}^{-1} \text { of } \mathrm{H}_{2} \text {. }
$$

The cell voltage, $\mathrm{E}_{\mathrm{eq}}^{\mathrm{O}}$ at equilibrium (no current flowing) under standard conditions, is thus:

$$
\mathrm{E}_{\mathrm{eq}}^{\mathrm{o}}=-\frac{\Delta \mathrm{G}_{\mathrm{o}}}{\mathrm{nF}}=\frac{237 \times 10^{3}}{2 \times 96485}=\mathrm{E}_{2}^{\mathrm{o}}-\mathrm{E}_{1}^{\mathrm{o}}=1.229 \mathrm{~V} \approx 1.23 \mathrm{~V}
$$

This process produces an electrical energy, $\mathrm{W}_{\mathrm{e}}=\mathrm{nFE} \mathrm{E}_{\mathrm{eq}}^{\mathrm{O}}=-\Delta \mathrm{G}^{\circ}$, corresponding to a mass energy density of the fuel, $W_{\mathrm{em}}=-\Delta \mathrm{G}^{\circ} /(3600 \mathrm{M})=32.9 \mathrm{kWh} \mathrm{kg}^{-1} \approx 33 \mathrm{kWh} \mathrm{kg}^{-1}$, with $\mathrm{M}=0.002 \mathrm{~kg}$ the molecular weight of hydrogen and $\mathrm{n}=2$ the number of electrons involved in the oxidation of one hydrogen molecule. However hydrogen has to be stored, either as a pressurized gas (200 to 700 bars) or in the liquid state (at 20K) greatly reducing the volumetric energy density ( $15 \mathrm{~g}$ to $71 \mathrm{~g}$ per liter), i.e. 1.5 to $12 \%$ weight storage density (0.5 to $4 \mathrm{kWh} \mathrm{kg}^{-1}$, instead of the theoretical density $33 \mathrm{kWh} \mathrm{kg}^{-1}$ ).

The working of the cell under reversible thermodynamic conditions does not follow Carnot's theorem, so that the theoretical energy efficiency, $\varepsilon_{c e l l}^{r e v}$, defined as the ratio of the produced electrical energy $(-\Delta \mathrm{G})$ to the chemical combustion energy $(-\Delta \mathrm{H})$, i.e. $\varepsilon_{c e l l}^{r e v}=\Delta \mathrm{G} / \Delta \mathrm{H}$, is very high, e.g. $83 \%$ for the hydrogen-oxygen fuel cell at $25^{\circ} \mathrm{C}$ under 
standard conditions, $97 \%$ for the DMFC and for the DEFC.

This theoretical efficiency is much greater (by a factor at least of 2) than that of a thermal combustion engine, producing the reversible work, $\mathrm{W}_{\mathrm{r}}$, according to Carnot's theorem:

$$
\varepsilon_{\text {therm }}^{\text {rev }}=\frac{W_{r}}{\left(-\Delta \mathrm{H}^{\circ}\right)}=1-\frac{Q_{2}}{Q_{1}}=1-\frac{T_{2}}{T_{1}}=0.43 \text { for e.g. } \mathrm{T}_{1}=350^{\circ} \mathrm{C} \text { and } \mathrm{T}_{2}=80^{\circ} \mathrm{C},
$$

where $\mathrm{Q}_{1}, \mathrm{Q}_{2}$ are the heat exchanged with the hot source and cold source, at temperature $\mathrm{T}_{1}$, $\mathrm{T}_{2}$, respectively.

\section{I.2 Proton Exchange Membrane Fuel Cell (PEMFC)}

One of the first PEMFC systems was developed in 1987 by Ballard Power Systems using a new ion-conducting polymer membrane from Dow Chemical, a sulfonated fluorocarbon polymer similar to Nafion ${ }^{\circledR}$. The power density achieved $\left(\approx 2 \mathrm{~W} \mathrm{~cm}^{-2}\right)$ was roughly a factor of 10 greater than that obtained for the other fuel cell systems. This may potentially lead to a significant reduction in stack size and cost compared to other fuel cells. PEMFC is now the most advanced fuel cell technology, and it can be used in several applications (space, electric vehicle, stationary power plants, portable electronics), the progress made in one application being beneficial to the others.

The main advantages of the PEMFC are that it may be operated at high current densities resulting in a power source which has a fast start capability, compact and light weight design, and where there is no corrosive fluid leakage because the only liquid present in the cell is water. Recent advances in performance and design offer the possibility of lower cost than any other fuel cell system.

The PEMFC can work either with pure hydrogen or $\mathrm{H}_{2}$ from reformed hydrocarbon fuels, or alcohols, and on oxygen from air. The PEMFC typically operates from $65^{\circ} \mathrm{C}$ to $80^{\circ} \mathrm{C}$. About $50 \%$ of maximum power is available immediately at room temperature. Full operating power is available within about 3 minutes under normal conditions. The low temperature of operation also reduces or eliminates the need for thermal insulation to protect personnel or other equipment.

The excess heat can be used for room heating or for residential hot water, but is not hot enough to generate steam for fuel reforming or for utility bottoming cycles. Thus, a PEMFC is well suited for use in vehicles and in portable electronics. A disadvantage associated with this type of fuel cell, however, is that Pt catalysts are required to activate the electrochemical reactions, leading to a relatively high cost of the system.

\section{I.3 Components of a PEM elementary cell}

An elementary PEMFC comprises several elements and components: the membrane-electrode assembly (MEA), the flow-field plate (bipolar plate, BP, which also ensures electric contact with the adjacent cell), gaskets to ensure tightness to reactants and end plates (Fig. 2). 
The membrane-electrode assembly, which is the heart of the PEMFC, consists in a thin $(10$ to $200 \mu \mathrm{m})$ solid polymer electrolyte (a proton exchange membrane, such as Nafion ${ }^{\circledR}$ ) on both sides of which are the electrode structures (fuel anode and oxygen cathode) (Fig. 3). The electrode structure comprises several layers: a first layer made of carbon paper (or cloth) to strength the structure, on which are coated the Gas Diffusion Layer (GDL), and then the catalyst layer (CL), directly in contact with the proton exchange membrane.

The ion exchange membrane serves as the separator between the anode where hydrogen is oxidized and the cathode where oxygen is reduced. In this system, oxygen may be either pure oxygen or oxygen from the air. Each electrode consists in a heterogeneous, porous layer that serves as electron conductor, ion conductor, and gas transport region. The catalytic reaction occurs at the three-phase contact with the catalyst. The catalyst is mainly platinum dispersed on a high surface area carbon (e.g. Vulcan XC72R), but any variety of catalysts, usually noble metals and their alloys, may be employed under different conditions. As the gases react, protons generated at the anode cross the membrane to the cathode, whereas electrons flow through the external circuit to reduce oxygen at the cathode. The membrane provides ionic conduction and prevents direct reaction of the hydrogen and oxygen at the platinum catalyst.

To produce electricity in large amounts, many cells are combined into a fuel cell stack. Bipolar plates separate neighbouring cells and serve as the anode for one fuel cell and the cathode for the adjacent one. To generate appropriate voltage and power, MEAs, connected by bipolar plates, are assembled in stack. Current is increased by using larger electrodes and stack voltage is increased by putting several elementary cells in series (filter type configuration). In a system, several conditions must be fulfilled for the fuel cell to generate appropriate power. The catalyst for the anode and cathode must be efficient. The membrane must be highly proton-conducting and sufficiently gas-tight to avoid any leakage of the potentially explosive fuel and oxidant. The catalyst layers must allow for effective and balanced transport of gases, electrons, and protons. Thermodynamically, the reactions of hydrogen and oxygen should give $1.23 \mathrm{~V}$ under standard conditions through a four electron/four proton process. Fuel cells do not give this thermodynamic voltage. Several important factors contribute to lower the electrical performance of PEM fuel cells. The kinetics of the anode and cathode reactions is not necessarily ideal. In particular, the oxygen reduction kinetics is a limiting factor, even with noble metal catalysts. The kinetics of hydrogen oxidation is usually not rate limiting, but questions remain as to whether or not hydrogen is the optimum fuel for a variety of fuel cell applications. These questions arise for reasons of safety, cost effective production of hydrogen, and efficient storage of hydrogen. Thus, the main difficulties with hydrogen fuel cells are the oxygen reduction electrocatalysis, the ionic conductivity and stability of the membrane, the crossover of reactants, and hydrogen storage. 
In a PEMFC working at low temperature $\left(20\right.$ to $\left.90^{\circ} \mathrm{C}\right)$ several problems still need to be solved to facilitate the large-scale technological development of fuel cell stacks for different applications. This concerns the components of the elementary cell, i.e. the proton exchange membrane, the electrode (anode and cathode) catalysts, the membrane - electrode assemblies and the bipolar plates [13].

The proton exchange membrane, which is a solid polymer electrolyte, plays a key role in the PEMFC. It allows the electrical current to pass through it due to its proton conductivity and prevents any electronic current through it in order that electrons are obliged to circulate in the external electric circuit to produce the electrical energy corresponding to the combustion reaction of the fuel ; it must avoid any gas leakage between the anodic and cathodic compartments, so that no chemical combination between hydrogen and oxygen is directly allowed ; it must be stable mechanically, thermally (up to $150^{\circ} \mathrm{C}$ in order to increase the working temperature of the cell) and chemically ; and finally its lifetime must be sufficient for practical applications (e.g. $>4000 \mathrm{hrs}$ for transportation power trains or $>40000 \mathrm{hrs}$ for stationary power plants).

The currently developed PEMFCs have a perfluorinated membrane, such as Nafion ${ }^{\circledR}$, which partially fulfils these requirements. Nafion ${ }^{\circledR}$ has excellent $e x$-situ chemical stability due to its perfluorocarbon backbone and the sulfonic acid groups of its side chains lead to high proton conductivity. In the absence of applied pressure, its conductivity decreases above $100^{\circ} \mathrm{C}$ because of its dehydration. On the other hand it is not completely tight to liquid fuels (such as alcohols). This is as more important as the membrane is thin (a few $10 \mu \mathrm{m}$ ). Furthermore its current cost is high $\left(>500 € \mathrm{~m}^{-2}\right.$ ), so that its use in a PEMFC for a low cost passenger electric car is actually difficult.

One of the main problems of low temperature PEMFCs is the relatively low kinetics of the electrochemical reactions involved, e.g. the oxygen reduction at the cathode and fuel (hydrogen from a reformate gas, or alcohols) oxidation at the anode. Another problem, particularly crucial for the electric vehicle, is the relatively low working temperature (70$80^{\circ} \mathrm{C}$ ), which prevents efficient exhaust of the excess heat generated by the power fuel cell.

On the other hand the intolerance of the catalysts to impurities such as carbon monoxide has led to the development of high temperature resistant membranes which can operate at $150-180^{\circ} \mathrm{C}$. This enables the catalysts to tolerate greater impurities in the hydrogen supply or from air in the oxygen supply.

Therefore new membranes are investigated with improved stability and conductivity at higher temperatures (up to $180^{\circ} \mathrm{C}$ ). For power FC the increase of temperature will increase the rate of the electrochemical reactions occurring at both electrodes, i.e. the current density at a given cell voltage and the specific power. Furthermore thermal management and heat utilization will be improved, particularly for residential applications with heat cogeneration, and for large scale applications to exhaust excess heat. 
The reaction rates can be increased by the simultaneous action of the electrode potential and electrode material (this is the field of electrocatalysis) [3-5]. On the other hand increasing the working temperature, e.g. from 65 to $150^{\circ} \mathrm{C}$, would greatly increase (by a factor of about 100 times, assuming an activation energy of about $65 \mathrm{~kJ} \mathrm{~mol}^{-1}$, value usually encountered for the ORR, which is the main limiting process in the overall kinetics) the rates of the electrochemical reactions (thermal activation). All these combined effects would increase the cell voltage by ca. 0.1 to $0.2 \mathrm{~V}$ leading to values close to $0.7-0.9 \mathrm{~V}$, instead of the $1.23 \mathrm{~V}$ theoretical cell voltage under standard conditions. The investigation of new electrocatalysts more active for the oxygen reduction and fuel oxidation (hydrogen from reformate gas, or alcohols) is thus an important challenge for the development of PEMFCs $[14,15]$.

The fabrication of the Membrane-Electrode Assembly (MEA) is a crucial point for a good fuel cell stack. The method currently used consists in hot-pressing (e.g. at $130^{\circ} \mathrm{C}$ and 35 $\mathrm{kg} \mathrm{cm}^{-2}$ ) the electrode structures on the polymer membrane (Nafion ${ }^{\circledR}$ ). This gives not very much reproducible results (in terms of interface resistance) and is difficult to scale-up. New concepts must be elaborated, such as the continuous assembly of the 3 elements using a rollto-roll process (like in the magnetic tape industry), or successive deposition of the component layers (microelectronic process), etc.

The bipolar plates, which separate both electrodes of neighboring cells (one anode of a cell, and one cathode of the other), have a triple role:

- to ensure the electronic conductivity between 2 neighboring cells,

- to allow the distribution of reactants (gases and liquids in the case of alcohols) to the electrode catalytic sites, and to evacuate the reaction products $\left(\mathrm{H}_{2} \mathrm{O}\right.$, and $\mathrm{CO}_{2}$, in the case of alcohols),

- to provide thermal management inside the elementary cell by evacuating the excess heat. The bipolar plates are usually fabricated with non porous machined graphite or corrosion resistant metal plates. Distribution channels are engraved in these plates. Metallic foams can also be used for distributing the reactants.

A more detailed scheme of a PEMFC system, including the auxiliary and control equipments, is given in Figure 4. Fuel supply is usually from liquid hydrogen or pressurized gaseous hydrogen. For other fuels a fuel processor is needed, which includes a reformer, gas shift reactors, and purification reactors, in order to decrease the amount of $\mathrm{CO}$ to an acceptable level (a few tens of ppm), which would otherwise poison the platinum-based catalysts. This equipment is still heavy and bulky and limits the dynamic response of the fuel cell stack, particularly for the electric vehicle in some urban driving cycle.

\section{I.4 Electrical characteristics of a PEM elementary Cell}

Under working conditions with a current density $\mathrm{j}$ (different from zero) the cell voltage $\mathrm{E}(\mathrm{j}$ ) becomes smaller than the equilibrium voltage $E_{\mathrm{eq}}$ as the result of reaction overvoltages $\eta_{\mathrm{a}}$ and 
$\eta_{c}$ at both electrodes ( $\eta$ is defined as the difference between the working electrode potential $\mathrm{E}_{(\mathrm{i})}$ and the equilibrium potential $\mathrm{E}^{(\mathrm{i})}{ }_{\mathrm{eq}}$ ), and ohmic losses.

This deviation from the thermodynamic reversible behavior leads to a decrease of the cell voltage by ca. 0.4 to $0.6 \mathrm{~V}$, which reduces the energy efficiency of the fuel cell by a factor $\varepsilon_{\mathrm{E}}=\mathrm{E}(\mathrm{j}) / \mathrm{E}_{\mathrm{eq}}$, called voltage efficiency $\left(\varepsilon_{\mathrm{E}}=0.70 / 1.23=0.57\right.$ for a cell voltage of $\left.0.70 \mathrm{~V}\right)$, so that the overall energy efficiency at $25^{\circ} \mathrm{C}$ for the $\mathrm{H}_{2} / \mathrm{O}_{2}$ Fuel Cell becomes $0.83 \times 0.57=0.47$.

For the elementary fuel cell, the cell voltage $\mathrm{E}(\mathrm{j})$ is the difference between the cathode potential $\mathrm{E}_{\mathrm{c}}$ and the anode potential $\mathrm{E}_{\mathrm{a}}$ :

$$
E(j)=E_{c}(j)-E_{a}(j)=E_{e q}-\left(\left|\eta_{a}\right|+\left|\eta_{c}\right|+R_{e} j\right)
$$

where $\mathrm{E}_{\mathrm{eq}}$ is the equilibrium cell voltage under the temperature and pressure working conditions, and $R_{e}$ is the specific resistance of the cell (membrane + interfacial resistances). In the $E(j)$ characteristics one may distinguish 3 zones associated with these energy losses (Figs.5a, b, c):

- $\quad$ Effect of the membrane properties (Zone I): the E vs. $j$ linear curve corresponds to ohmic losses $\mathrm{R}_{\mathrm{e}} \mathrm{j}$ in the membrane and interface resistances; a decrease of the electric resistance $R_{e}$ from ca. 0.3 to $0.15 \Omega \mathrm{cm}^{2}$ leads to an increase of the current density $j$ (at $0.7 \mathrm{~V}$ ) from $0.25 \mathrm{~A} \mathrm{~cm}^{-2}$ to $0.4 \mathrm{~A} \mathrm{~cm}^{-2}$, i.e. an increase in the energy efficiency and in the power density by 1.6 times (Fig 5a). This was experimentally observed by Ballard Power Systems when comparing the Nafion ${ }^{\circledR}$ and Dow ${ }^{\circledR}$ membranes (Fig 6) [16].

- $\quad$ Effect of the nature of the catalytic layer (Zone II): the E vs. $\ln \left(j / j_{\mathrm{o}}\right)$ logarithmic curve corresponds to the charge transfer polarization, i.e. to the activation overvoltages due to a relatively low electron exchange rate at the electrode-electrolyte interface, particularly for the oxygen reduction reaction whose exchange current density $j_{o}$ is much smaller than that of the hydrogen oxidation: an increase of $\mathrm{j}_{\mathrm{o}}$ from $10^{-8}$ to $10^{-6} \mathrm{~A} \mathrm{~cm}^{-2}$ leads to an increase of the current density $\mathrm{j}$ (at $0.7 \mathrm{~V}$ ) from 0.4 to $0.9 \mathrm{~A} \mathrm{~cm}^{-2}$, i.e. an increase in the energy efficiency and in the power density by 3.6 times compared to the initial curve (Fig 5b). This is illustrated by the cell voltage and power density vs. current density characteristics of a Direct Ethanol Fuel Cell (DEFC) where the kinetics of ethanol electroxidation is rather slow (Fig 7) [17]. - $\quad$ Effect of the structure of the gas diffusion layer (Zone III): the E vs. $\ln \left(1-\mathrm{j} / \mathrm{j}_{1}\right)$ logarithmic curve corresponds to concentration polarization which results from the limiting value $\mathrm{j}_{1}$ of the mass transfer limiting current density for the reactive species and reaction products to and/or from the electrode active sites ; an increase of $j_{1}$ from 1.4 to $2.2 \mathrm{~A} \mathrm{~cm}^{-2}$ leads to a further increase of the current density $\mathrm{j}$ (at $0.7 \mathrm{~V}$ ) from 0.9 to $1.5 \mathrm{~A} \mathrm{~cm}^{-2}$, i.e. an overall increase in the energy efficiency and in the power density by 6 times compared to the initial curve (Fig 5c). This was experimentally observed for 3 different gas diffusion layer (GDL) of different composition at the air cathode: a micro-porous layer (MPL) coated with $30 \%$ wt. FEP, and 2 other FEP impregnated layers with 30 and $10 \%$ wt. FEP, respectively (Fig 8) [18]. 
Thus these 3 key points will determine the energy efficiency and the specific power of the elementary fuel cell: in these examples an improvement in each component of the cell will increase the power density from $0.175 \mathrm{~W} \mathrm{~cm}^{-2}$ to $1.05 \mathrm{~W} \mathrm{~cm}^{-2}$, i.e. an increase by a factor of 6 . As a consequence for the fuel cell systems the weight and volume will be decreased by a similar factor, for a given power of the system, and presumably the overall cost will be similarly diminished. The improvement in the components of the elementary fuel cell has a direct effect on the system technology and therefore on the overall cost.

This is summarized in Table 1, where the estimated costs of the different components of the MEA (membrane, catalyst, etc.) and the total cost of the materials used in the MEA of a $63 \mathrm{~kW}$ fuel cell power train (for an electric vehicle taken as an example) are discussed according to the power density of the elementary cell. Thus a target cost of $50 € / \mathrm{kW}$ (EU FP7 and US DoE targets for the electric vehicle) can only be reached with improved performance, i.e. for a power density of the MEA at least of $1 \mathrm{~W} \mathrm{~cm}^{-2}$.

\section{EXPERIMENTAL RESULTS OBTAINED IN THE GDR PACTE}

The Research Grouping ${ }^{\circ} 2985$ of CNRS (GDR PACTE) aims to coordinate the research activity of several teams of CNRS Laboratories involved in the basic understanding and technological development of PEMFC components. In particular the investigation of new catalysts, both for the ORR and for the oxidation of reformate-hydrogen and alcohols, are carried out, together with the synthesis of new Proton Exchange Membranes with high proton conductivity and stability at higher temperatures (until $150-180^{\circ} \mathrm{C}$ ). Besides, some other research teams focus their activity on the characterization and optimization of MEAs fabricated with the components (membrane, catalysts, etc.) developed by the previously cited teams.

\section{II.1 Membrane Development Needs}

In recent years, a great number of polymers have been proposed and evaluated as possible electrolytes for PEMFCs, in particular for automotive application. Sulfonic acid functionalized perfluorinated polymers are a class of benchmark materials having excellent proton conductivity, mechanical and chemical stabilities. The Dupont $\mathrm{Nafion}^{\circledR}$, the $3 \mathrm{M}^{\mathrm{TM}}$ and the Solvay-Solexis Aquivion ${ }^{\mathrm{TM}}$ membranes are representative of perfluorosulfonic acid (PFSA) ionomers. These differ in one or more of the following items: length of the perfluorovinylether side chain, presence or not of pendant $-\mathrm{CF}_{3}$ group, molar ratio of tetrafluoroethylene (TFE) and side-chain functionalized TFE, all of which impart specific properties. For example, a shorter side chain without the pendant $\mathrm{CF}_{3}$ group gives a polymer 
of higher crystallinity and higher glass transition temperature at a given polymer equivalent weight (EW) or ion exchange capacity (IEC). Aquivion ${ }^{\mathrm{TM}}$ membranes have been operated at temperatures up to $110-120^{\circ} \mathrm{C}$ in stacks developed in the FP6 Autobrane "automotive fuel cell membranes" project [19], and they represent a viable option for automotive and small stationary applications, although their long-term durability at higher temperatures must be increased. With the trend to higher temperature of operation, and the requirement for higher performance, recent developments have tended towards low EW PFSA polymer membranes, having a high density of sulfonic acid groups, and in the use of membranes of thickness only 25-30 $\mu \mathrm{m}$ (compared with the use of membranes of ca. $175 \mu \mathrm{m}$ some 10 years ago), thin membranes being required for their low area specific resistance. In particular, in conditions of use of stop/start or load cycling, the variation in relative humidity causes membrane swelling and contraction particularly exacerbated in low EW polymer membranes. In this respect, short side chain PFSA polymer membranes such as Aquivion ${ }^{\mathrm{TM}}$ appear to have some advantages over long side chain Nafion ${ }^{\circledR}$ type membranes due to a higher degree of crystallinity as indicated by heat of fusion data. Nevertheless, in such membranes unsatisfactory mechanical properties remain a limitation for cell and stack lifetime.

A series of approaches for the covalent cross-linking of PFSAs in order to improve membrane mechanical properties and reduce membrane swelling in the presence of water have been screened and are under further development. On the one hand, novel side-chain component multifunctional monomers have been developed that are cross-linkable after membrane fabrication, and can lead, for example, to triazine, or perfluorobutyl cross-links [20]. On the other hand, methodologies have been devised for cross-linking of low EW membranes in sulfonyl fluoride precursor form, with subsequent conversion to the sulfonic acid form [21]. In all cases, the degree of cross-linking must be fine-tuned in order to achieve the required mechanical stabilization without detriment to the proton conductivity. The reactive cross-linking procedures have been designed to meet with both solution casting and extrusion techniques for large scale manufacture of membranes. The cross-linking of long side chain PFSA through sulfonimide bridges is shown in Figure 9.

Characterization of the degree of cross linking is not trivial in such systems; however recent work has shown the use of X-ray photoelectron spectroscopy to demonstrate unequivocally the presence of sulfonimide groups [22], while indirect evidence for crosslinking is inferred by the significant reduction in water uptake and dimensional swelling in the cross-linked membranes (Fig. 10).

Many significant advances have been made in the design and development of a broad 
range of polymers and membranes as alternatives to conventional PFSA type [23]. These materials generally have more facile preparation routes, and are less costly than perfluorinated materials. These new materials have primarily explored radiation induced graft polymerization on per- or partially fluorinated aliphatic polymers [24], and development of sulfonated aromatic or heterocyclic polymers, in particular polysulfones [25], polyetherketones [26], polybenzimidazoles [27] and polyimides [28], in which the protogenic groups are covalently bound either to the polymer backbone or via a spacer. Polyaromatic polymers have generally been preferred because of their thermal and chemical stabilities. PBI polymers are particularly thermally and chemically stable and novel ether-linked polybenzimidazoles can be functionalized by direct sulfonation in heterogeneous [27] or homogeneous [29] media, with control both of the degree and the site of sulfonation reaction. Appropriate polymer design also allows for discriminatory cross-linking between polymer chains. A recent example is the direct sulfonation in solution of poly(arylene ether benzimidazole), poly[(1-(3,3'-phthalido- $p$-phenylene)-5-oxybenzimidazole)-benzimidazole] (PBI-OPh) (Fig. 11), for which the effect of the nature of the sulfonating agent (concentrated or fuming sulfuric acid), temperature and duration of the reaction on degree and site of sulfonation (using 2D $\operatorname{COSY}{ }^{1} \mathrm{H}$ NMR) were investigated [30]. At all reaction temperatures studied, only the sites located in proximity to the ether linkages of the polymer are sulfonated using concentrated $\mathrm{H}_{2} \mathrm{SO}_{4}$, while the use of fuming sulfuric acid allows sulfonation also of less electrophilic sites, and the preparation of samples with a high degree of sulfonation (>430\%). The difference in the distribution of sulfonic acid groups in samples prepared by sulfonation in concentrated or fuming sulfuric acid affects the observed water uptake properties and proton conductivity, the most highly conducting samples $\left(25 \mathrm{mS} \mathrm{cm}^{-1}\right.$ at $25^{\circ} \mathrm{C}$ and $100 \%$ relative humidity) being those in which percolation is favored through substitution concomitantly at the ether-linked and Cardo segments of the polymer (Fig. 11).

All the above materials have relied on the presence of water as proton carrier. Although practicable at lower temperatures, water management at temperatures higher than $100^{\circ} \mathrm{C}$ has a significant impact on the viability of the membrane electrode assembly (MEA) and on the overall operation of the system. Over the last decade, new concepts have evolved engaging alternative proton carriers that mark a move towards reducing the need for high levels of hydration of the fuel cell membrane [31]. The ideal protogenic group in a "quasianhydrous" membrane environment should be amphoteric, exhibit proton donor and acceptor properties and show a high degree of self-dissociation. It also should have a high dielectric 
constant to enhance the charge separation and be stable under fuel cell operation conditions. Acid-doped polybenzimidazole, in which the phosphoric acid electrolyte is in liquid form in a non-functionalised polymer matrix [32], may be considered as a prime example. Fuel cells incorporating these membranes have reached a certain level of technological maturity for use in MEAs operating above $150^{\circ} \mathrm{C}$, with stack and system being commercially available. However this type of membrane is presently not suitable for operation at temperatures lower than $100^{\circ} \mathrm{C}$ or under automotive conditions, where water can condense and dilute or leach the electrolyte, and further efforts are required to immobilise the protogenic groups, for example as phosphonic acid groups on a polymer backbone. While early work on model compounds or polymers having a low concentration of grafted phosphonic groups led to electrolytes of rather low conductivity [33], on-going investigations have identified two factors important for high intrinsic conductivity: firstly that a high local concentration of phosphonic acid groups is required and secondly that membrane morphology is of great importance since it is essential that the acidic groups be able to locally cluster into phosphonic acid rich domains [34]. Recent work in collaboration with BASF Fuel Cell has demonstrated particularly encouraging fuel cell performance for high temperature PEMFC using membranes based on PBI and poly(vinylphosphonic) acid. With this high temperature ionomer, performance increases with temperature (to $190^{\circ} \mathrm{C}$ ) and with pressure, and for operation on hydrogen and air hydrated respectively at 80 and $64^{\circ} \mathrm{C}$, a power density of $0.5 \mathrm{~W} \mathrm{~cm}^{-2}$ is obtained at $160^{\circ} \mathrm{C}$ and 3 bar abs (Fig. 12) [35]. Under conditions of accelerated thermal ageing at $190^{\circ} \mathrm{C}, 3000 \mathrm{~h}$ of operation were reached, with a cell voltage degradation rate of ca. $10 \mu \mathrm{V} \mathrm{h}^{-1}$.

\section{II.2 New preparation methods of efficient electrode catalysts}

According to equation (6) in section I.4, for a given solid electrolyte (of known specific resistance $R \mathrm{e}$ ), the increase of the potential efficiency of a fuel cell is directly related to the decrease of the overpotentials of the oxygen reduction and fuel oxidation reactions, and needs therefore the enhancement of the catalyst activity at low overpotentials. Until now, platinum appears unavoidable as a catalytic material for activating the oxygen reduction reaction and fuel dissociative adsorption. In the case of PEMFCs, the decrease of platinum loading is relatively easy at the anode due to very high hydrogen oxidation reaction kinetics, whereas the oxygen reduction reaction (ORR) is known to greatly limit the PEMFC performances [15]. However, in the case of Direct Alcohol Fuel Cells (DAFCs), both electrodes display low reaction kinetics [15]. Due to its high cost and low availability on earth, the decrease of platinum loading in fuel cell electrodes is one of the main issues for a 
large scale development of PEMFCs and DAFCs.

To decrease the amount of platinum, several solutions have been proposed: decrease of the platinum particle size, localization of the platinum layer as close as possible to the electrolytic membrane, synthesis of bimetallic platinum-based catalysts and development of non platinum-based catalysts. Non-noble metal catalysts based on chalcogenides [36-39] and macrocycles of transition metals [40-44] have shown good activity for the ORR. However these materials did not yet match the catalytic activity of dispersed platinum. To achieve economic metal loadings, fuel cell electrodes have to be designed from Pt nanoparticles $(\mathrm{d}<5$ $\mathrm{nm}$ ) supported on high-surface-area carbon black, such as Vulcan XC72R. Indeed, for the ORR the specific activity ( $\mathrm{SA}$ in $\mathrm{A} \mathrm{cm}_{\mathrm{Pt}}^{-2}$ ) decreases when decreasing the particle size, while SA for larger particles $(d>5 \mathrm{~nm})$ is approximately the same as for the smooth platinum electrode [45]. As a result, the plots of mass activity (MA in $\mathrm{A} \mathrm{g}^{-1} \mathrm{Pt}$ ) versus particle size for oxygen reduction in a sulfuric or a phosphoric acid electrolyte exhibit a marked maximum at $\mathrm{d}=3.5 \mathrm{~nm}$ [45]. Ultra-low Pt loading electrodes (anodes and cathodes) prepared by plasma sputtering technique have led to excellent fuel cell performance (see section II.4). This was partly explained by a very high platinum utilization efficiency, due to its localization very close to the membrane leading to increase the density of the triple phase boundary where electrochemical reactions occurs [46].

Numerous studies have shown that platinum-based binary electrocatalysts such as $\mathrm{PtFe}, \mathrm{PtCo}, \mathrm{PtNi}$, and $\mathrm{PtCr}$ exhibit a higher catalytic activity for the ORR in acid electrolytes than pure platinum [47-53]. For alcohol oxidation, Pt-based bimetallic catalysts were also developed in order to increase the anode activity and selectivity [54-57]. Because all considered reactions in fuel cells are known to be structure sensitive, a versatile catalyst synthesis method, derived from a colloidal route developed by Bönnemann at al. [58-62], has been used and slightly modified to obtain multimetallic platinum-based materials. This method allows varying easily the foreign metal nature, the atomic composition and the microstructures of the catalysts $[61,62]$. The synthesis is carried out under a controlled atmosphere (argon) free of oxygen and water, with non-hydrated metal salts $\left(99.9 \% \mathrm{PtCl}_{2}\right.$, $\mathrm{RuCl}_{3}, \mathrm{SnCl}_{2}, \mathrm{CoCl}_{2}, \mathrm{NiCl}_{2}, \mathrm{FeCl}_{2}$, etc., from Alfa Asear). Briefly, the first step consists in the preparation of a tetraalkyl triethylborohydride reducing agent $\left(\mathrm{Nalk}_{4}\right)^{+}\left(\mathrm{Bet}_{3} \mathrm{H}\right)^{-}$, which will also act as a surfactant after metal salt reduction, preventing any agglomeration of the metallic particles. The colloidal precursors are then dispersed on a carbon support (e.g. Vulcan XC72 thermally treated at $400^{\circ} \mathrm{C}$ under a nitrogen atmosphere for $4 \mathrm{~h}$ in order to clean it) and thermally treated at $300^{\circ} \mathrm{C}$ for $1 \mathrm{~h}$ under air atmosphere to remove the organic surfactant, in 
order to obtain a metal loading of $40 \mathrm{wt} \%$. Different possibilities for the synthesis of supported multi-metallic catalysts are allowed:

(1) Synthesis of catalysts with a controlled atomic ratio by co-reduction of different metal salts and formation of the colloid precursor before the deposition step on carbon (Fig. 13a): $x \mathrm{PtCl}_{2}+y \mathrm{MCl}_{\mathrm{n}}+(2 x+\mathrm{n} y)\left[\left(\mathrm{Nalk}_{4}\right)^{+}\left(\mathrm{Bet}_{3} \mathrm{H}\right)^{-}\right] \rightarrow$

$$
\mathrm{Pt}_{x} \mathrm{M}_{y}\left[\left(\mathrm{Nalk}_{4}\right)^{+} \mathrm{Cl}^{-}\right]_{(2 x+n y)}+(2 x+\mathrm{ny}) \mathrm{BEt}_{3}+((2 x+\mathrm{n} y) / 2) \mathrm{H}_{2}
$$

(2) Synthesis of catalysts with a controlled atomic ratio by co-deposition of different metal colloids before the thermal treatment step and formation of the catalytic powder (Fig. 13b):

$x \operatorname{Pt}\left[\left(\mathrm{Nalk}_{4}\right)^{+} \mathrm{Cl}^{-}\right]_{2}+\mathrm{y} \mathrm{Me}\left[\left(\mathrm{Nalk}_{4}\right)^{+} \mathrm{Cl}^{-}\right]_{\mathrm{n}} \stackrel{300^{\circ} \mathrm{C}, \mathrm{C}}{\longrightarrow}\left(\mathrm{Pt}_{x}+\mathrm{M}_{y}\right) / \mathrm{C}$

TEM pictures were recorded to check the dispersion of $\mathrm{Pt} / \mathrm{XC72}$ catalysts, as well as to determine the mean apparent particle size. Figure 14a shows, as an example, a typical TEM micrograph of a freshly prepared $\mathrm{Pt}(30 \mathrm{wt} \%) / \mathrm{XC} 72$ catalytic powder. Platinum particles look round-shaped and are relatively well dispersed on the carbon support, although some entities with misshapen aspects are visible. For this reason, the Feret diameter, which takes into account the particle shapes, was used to establish the size distribution. The related histogram realized by counting isolated platinum entities is given in Figure 14b. A mean particle size $\mathrm{d}_{\text {TEM }}$ of $2.4 \pm 0.4 \mathrm{~nm}$ is calculated. Table 2 gives the structural data determined for bimetallic $\mathrm{PtRu}$ catalysts, with an atomic ratio $0.8(\mathrm{Pt}) / 0.2(\mathrm{Ru})$ as an example. The co-reduced $\mathrm{Pt}_{0.8} \mathrm{Ru}_{0.2} / \mathrm{C}$ catalyst displays well dispersed particles with a narrow size distribution (Fig. 15a), a mean particle size close to $2 \mathrm{~nm}$ and an alloy character as determined in a previous work from XRD measurements [61], whereas the co-deposited $\left(\mathrm{Pt}_{0.8}+\mathrm{Ru}_{0.2}\right) / \mathrm{XC72}$ catalyst displayed also a mean particle size close to $2 \mathrm{~nm}$, but analysis of the XRD pattern (Fig. 15b) indicated that the compound was not an alloy, but looked like particles of platinum in strong interaction with smaller ruthenium particles, maybe a decoration of platinum particles by very small ruthenium particles.

PtRu catalysts are very active for the oxidation of carbon monoxide arising either from the dissociative chemisorption of many alcohols (methanol, ethanol, etc.) or contained in small amounts into reformate gases. In both cases the presence of $\mathrm{Ru}$ allows $\mathrm{CO}$ to be oxidized at lower anodic potentials than at pure Pt electrodes, thus preventing the deactivation of Pt catalysts by strong poisoning of the active sites. As previously shown [63], platinum particles decorated with ruthenium (i. e. PtRu catalysts obtained via the co-deposition process) displayed higher activity towards the oxidation of hydrogen in a reformate gas or methanol than alloyed particles of the same atomic composition. The best composition of 
$\mathrm{PtRu}$ catalysts depends greatly on the working potential [61]. This fact can be related to the change in the rate-determining step as a function of potential.

PtM catalysts $(\mathrm{M}=\mathrm{Co}, \mathrm{Fe}, \mathrm{Ni})$ were also synthesized for the ORR. In the case of nominal $\mathrm{Pt}_{0.75} \mathrm{M}_{0.25} / \mathrm{XC72}$ catalysts as examples, TEM analyses showed that the mean size of isolated particles was in the range of $2.0-2.5 \mathrm{~nm}$ (Table 3). EDX analyses allowed to evaluate the bulk catalyst atomic compositions and to compare them with the nominal one. The PtFe catalyst displayed a bulk composition close to the nominal one, whereas the PtCo and above all the PtNi catalyst were platinum rich. Different reasons could be invoked to explain this fact, as for example: i) the metal salt solubility in THF (used as solvent in the Bönnemann's method) could be different; ii) the reduction kinetics of metal salt could also be different, which could lead to the enrichment of the particle surface by the less noble metal, followed by dissolution (de-alloying) during the cleaning step of the particles. XRD patterns of the different PtM/XC72 catalysts (Fig. 16) display the typical diffraction peaks of the platinum fcc structure. On the one hand, the analysis of the patterns showed that the crystallite size of bimetallic catalysts was close to that of the Pt/XC72 sample, i.e. close to ( $2 \mathrm{~nm})$. On the other hand, a low contraction of the cell parameter could be detected (shift of the diffraction peaks toward higher $2 \theta$ values). This low cell parameter contraction (ca. $2 \mathrm{pm}$ for $\mathrm{PtCo}$ and $6 \mathrm{pm}$ for $\mathrm{PtNi}$ and $\mathrm{PtFe}$ ) is related to the fraction of the second metal in the alloy.

The active surface area, as calculated by integrating the charge in the hydrogen adsorptiondesorption region of a cyclic voltammogram recorded at a sweep rate of $20 \mathrm{mV} \mathrm{s}^{-1}$ in $\mathrm{N}_{2^{-}}$ saturated electrolyte, was found to be ca. $50 \mathrm{~m}^{2} \mathrm{~g}^{-1}$ for $\mathrm{PtFe} / \mathrm{C}, 55 \mathrm{~m}^{2} \mathrm{~g}^{-1}$ for PtNi/C and $65 \mathrm{~m}^{2}$ $\mathrm{g}^{-1}$ for $\mathrm{PtCo} / \mathrm{C}$, comparatively to $45 \mathrm{~m}^{2} \mathrm{~g}^{-1}$ for $\mathrm{Pt} / \mathrm{C}$.

The oxygen reduction reaction was studied by rotating disc electrode (RDE) voltammetry recorded at $3 \mathrm{mV} \mathrm{s}^{-1}$ and with an electrode rotation rate of $2500 \mathrm{rpm}$; the kinetics data (Tafel slopes, limiting current density and kinetic current density) were evaluated from the Koutecky-Levich equation. Figure 17 and Table 3 indicate that all bimetallic catalysts lead to higher catalytic activity towards the ORR as higher current densities are recorded at high electrode potentials. The $\mathrm{PtCo} / \mathrm{XC} 72$ catalyst, although being that displaying the lower alloying ratio, leads to the higher kinetic current density measured at $0.95 \mathrm{~V}$ vs. RHE. The activity order is: $\mathrm{Pt}<\mathrm{PtNi} \sim \mathrm{PtFe}<\mathrm{PtCo}$. On the other hand, it was checked using a rotating ring disc electrode (RRDE) that no hydrogen peroxide was formed on the catalytic electrode from $1.1 \mathrm{~V}$ to $0.7 \mathrm{~V}$ vs. RHE. Then, replacing 10 to $20 \%$ of the platinum atoms by a non noble metal leads to increase the catalytic activity without modifying the selectivity towards water production. The observed electrocatalytic enhancement was interpreted either by an 
electronic effect, i.e. the change of the "d band" vacancy in Pt upon alloying, and/or geometric effects (Pt coordination number and Pt-Pt distance). Both effects may enhance the reaction rates of oxygen adsorption and of the breaking of the $\mathrm{O}-\mathrm{O}$ bond during the reduction reaction. For example, the lattice parameter $\mathrm{a}_{0}$ in the case of a cubic PtX catalyst $(\mathrm{X}=\mathrm{Fe}, \mathrm{Co}, \mathrm{Ni})$ decreases with an increase of the amount of the alloying component $\mathrm{X}$ leading to a variation in the catalytic behavior. In the case of PtNi alloys the maximum electrochemical activity for ORR was found to be at 30 at\% Ni [51]. Different works available in the literature pointed out several interesting properties of PtCo alloys as catalysts for the ORR: a higher active surface area [64], an increase of the free 5d electronic orbital density [51], a more favorable Pt-Pt interatomic distance [65], and hence a more favorable surface structure for the ORR, and even a better resistance towards sintering [66].

Platinum cluster deposition by plasma sputtering is an other suitable way for decreasing the catalyst loading onto relevant material supports, e.g. gas diffusion layer supported on carbon cloth or paper. The simple exposure of an un-catalyzed gas diffusion layer to a flux of platinum atoms leads to the diffusion of the metal atoms into the gas diffusion layer (GDL) to a sufficient depth. Low Pt loading electrodes can be produced leading to achieve convenient fuel cell performance. Plasma sputtering has thus the advantage of controlling the depth profile and reducing the amount of catalyst by localizing the catalytic material as close as possible to the electrolyte membrane [67-76]. Platinum can be sputtered in many manners depending on the plasma sources. Magnetron sputtering and Inducing Coupled Plasma (ICP) sputtering are the main ways to handle deposition of the required $\mathrm{Pt}$ nanoclusters [68-75], allowing preparing different kinds of platinum-based thin films. The control of the deposition parameters (target composition, chamber pressure, bias voltage applied between the targets and the substrate, energy of the plasma, distance between target and substrate, etc.) allows to control the deposited quantity, the film morphology, and the depth repartition of platinum inside the gas diffusion layer. Figure 18a shows as an example a typical scanning electron microscopy image obtained after deposition by plasma sputtering of $80 \mu \mathrm{g}_{\mathrm{Pt}} \mathrm{cm}^{-2}$ on a Gas Diffusion Layer. The carbon support appears completely recovered by a platinum film made of compacted platinum clusters in the size range from 1 to $5 \mathrm{~nm}$. An interesting feature of plasma sputtering deposition is the layered structure. It is often a columnar structure (Figs. 18b and c) due to low lateral mobility of atoms at ambient temperature deposition. Such a structure is meaningful for PEMFC electrodes. Indeed, codeposition or alternate deposition of carbon and platinum can lead to multilayer C-Pt catalysts or carbon columns decorated by a gradient of Pt nanoclusters [77, 78]. Moreover, the 
structures of Gas Diffusion Electrodes (GDE) prepared either by alternate deposition or by codeposition (from a target composed of $1 \mathrm{wt} \% \mathrm{Pt}$ and $99 \mathrm{wt} \% \mathrm{C}$ ) of platinum atoms and carbon atoms on the GDL are completely different, as SEM images of the cross section of the GDEs, given in Figures $18 \mathrm{~b}$ and $\mathrm{c}$, show clearly that the density of platinum is higher on the top of the GDE in the case of the alternate deposition, whereas its repartition seems more homogeneous in the case of co-sputtering. The reduction of the Pt quantity can be successfully achieved due to the Pt concentration profile in the GDL, penetrating to a shallowness of the GDL (over a thickness of $200-700 \mathrm{~nm}$ ) and exhibiting a decreasing platinum amount from the side being in contact with the polymer electrolyte to the depth of the GDL (Fig. 19). Due to this controlled localisation of platinum clusters in the GDL, the

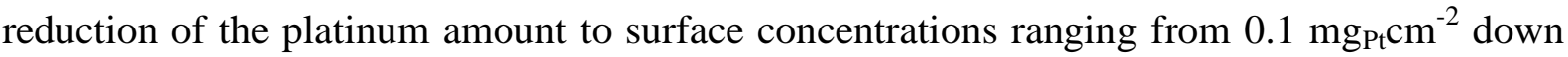
to $0.01 \mathrm{mg}_{\mathrm{Pt}_{\mathrm{t}}} \mathrm{cm}^{-2}$ has been achieved [76, 79-81]. Figure 20 shows a comparison of the polarization curves and power density curves obtained for several MEAs with low platinum loadings prepared via plasma sputtering and a classical MEA fabricated with electrodes loaded at $0.35 \mathrm{mg}_{\mathrm{Pt}} \mathrm{cm}^{-2}(\mathrm{Pt} / \mathrm{C}$ catalyst from E-tek). Remark that the maximum power density of the cells fitted with plasma electrodes is only reduced by a factor 2 comparatively to the classical MEA, whereas the platinum loading in the electrodes was decreased by factors

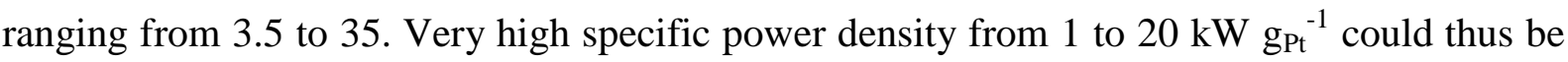
achieved with such electrodes, as seen in Figure 21 [81]. Such a result is the greatest performance obtained to date, as recognized recently [82]. It should be noticed that, conversely to classical MEA $[83,84]$, no Nafion ${ }^{\circledR}$ solution is added in the electrode catalytic layers before testing them in a $5 \mathrm{~cm}^{2}$ PEMFC fed with pure $\mathrm{H}_{2}$ and $\mathrm{O}_{2}$ gases and no hot pressing is necessary. This confirms that the localisation of platinum the nearest as possible to the membrane leads to increase its utilization efficiency. Moreover, the process for fabricating MEAs is simplified, which leads to decrease their cost.

The deposition of Pt alloy is also easily available using such a technique by simply adding one or more targets facing the substrate, e.g. carbon cloth of paper. In this case, the various possibilities in powering the targets will lead to different compositions and structures of the growing catalyst clusters. Simultaneous and alternate depositions are expected to explore the various possible structures: alloyed nanoclusters, separated pure elements nanoclusters and core shell nanostructures [85].

\section{II.3 Characterization of the MEA by Electrochemical Impedance Spectroscopy}

Electrochemical Impedance Spectroscopy (E.I.S) is a very powerful characterization 
technique, which allows separating and characterizing the various phenomena involved in electrochemical systems in order to optimize the whole process [86]. The ac impedance technique considered for PEMFC, has been increasingly used in recent years, particularly for characterizing MEA. Most of the EIS studies have been focused rather on the optimization of cathode structure and composition [87] (i.e. catalyst utilization and performance) than on the understanding of kinetic mechanisms [88]. Many studies investigated phenomena occurring in the active layer, and some attention has been paid to the transport limitation inside the gas diffusion layer [89].

EIS appears to be of great interest for providing a better understanding of transport and transfer limitations in PEMFCs. Some theoretical works have been devoted to predicting the direct (dc) and alternating current (ac) responses of the active layer [90] and the ac behavior of the gas diffusion layer [91]. For PEMFC, experimental impedance diagrams exhibit one or two depressed semicircle depending on the operating conditions.

PEMFCs should be able to operate at high current densities with an acceptable efficiency, i.e. at a relatively high cell voltage $\left(\mathrm{E}_{\text {cell }}>0.7 \mathrm{~V}\right)$. Losses inherent to high current densities are ohmic losses and slow gas diffusion to the electrodes. These transport limitations add to the limited interfacial kinetics of the Oxygen Reduction Reaction (ORR) and Hydrogen Oxidation Reaction (HOR) in the active layer.

The MEA has to be optimized to allow supplying the reactant species $\left(\mathrm{O}_{2}\right.$ and $\left.\mathrm{H}_{2}\right)$ and charges $\left(\mathrm{H}^{+}, \mathrm{e}^{-}\right)$to the three phase boundary interfaces.

\section{Ac response of the active layer}

For low current densities when mass and charge transport limitations remain negligible, the electrode impedance is represented in the complex plane plot by only one semicircle which corresponds to the contribution of charge transfer resistance in parallel with the double layer capacitance. As expected, the semicircle diameter decreases when the current density increases.

Conversely, when diffusion in the active layer is partly controlling the kinetics process, it is well-known that a limiting current behavior does not occur, but rather a doubling of the effective Tafel slope in a steady-state polarization curves [92] and a capacitive loop may be distinguished at low frequency (Fig. 22). Nevertheless, the separation of the charge transfer resistance and diffusion arcs clearly appears only when considering a very small double layer capacitance: decreasing the double layer capacitance leads to shift the frequency domain of the charge transfer arc towards higher frequencies [93]. It means that the formation of a capacitive loop at low frequencies is directly related to concentration gradient for 
dissolved oxygen in the active layer. Therefore, the contribution of diffusion in the active layer appears in the complex plane plot as a nearly perfect semicircle according to other authors.

In agreement with previous studies, the diffusion limitation effect within active layers on polarization curves and impedance spectra for GDE is only partial. Under diffusion control, the tendency to a doubling of the apparent Tafel slope in the dc response corresponds to a polarization resistance, which is at most twice the charge transfer resistance in the ac response. However the active layer situation alone never leads to such a limiting current, because catalyst particles are always present in a region of nonzero concentration close to the active layer/diffusion backing interface. Moreover, a straight line at a $45^{\circ}$-angle could be respectively distinguished in the high-frequency limit. Such a behavior could be attributed to ionic transport into the active layer, which dominates the overall electrode response for high frequencies in the case of low ionic conductivity.

The influence of the active layer thickness (L) and roughness factor $(\gamma)$ has been investigated by using a previous published model [93]. The general model is limited to a one-dimension and considers the effects related to ohmic losses and losses due to diffusion within the active layer, interfacial charge transfer and double layer charging. This one-dimensional dc and ac model of the active layer can be developed by considering conservation of mass and charge, transport of species and the reaction kinetics. On the one hand, the equation of continuity for a species $X_{i}$ in the electrolyte can be written classically for a porous media as:

$$
\frac{\partial\left[\mathrm{X}_{\mathrm{i}}\right]}{\partial \mathrm{t}}-\mathrm{D}^{\mathrm{eff}} \frac{\partial^{2}\left[\mathrm{X}_{\mathrm{i}}\right]}{\partial \mathrm{x}^{2}}+\frac{\gamma}{\mathrm{L}} \frac{\mathrm{j}_{\mathrm{f}}}{\mathrm{n}_{\mathrm{e}} \mathrm{F}}=0
$$

where $\mathrm{D}^{\text {eff }}$ represents the effective diffusion coefficient, $\mathrm{n}_{\mathrm{e}}$ the exchange number of electron, $\mathrm{F}$, the Faraday's constant and $\mathrm{j}_{\mathrm{f}}$ the current density.

On the other hand, Ohm's law in the electrolyte phase, the continuity equation which describes the transformation of reacting species into electronic current via faradic processes and the double layer charging, must be taken into account [93]. This leads to the charge balance equation:

$$
\frac{\gamma}{\mathrm{L}} \mathrm{C}_{\mathrm{dl}} \frac{\partial \eta}{\partial \mathrm{t}}-\kappa^{\mathrm{eff}} \frac{\partial^{2} \eta}{\partial \mathrm{y}^{2}}+\frac{\gamma}{\mathrm{L}} \mathrm{j}_{\mathrm{f}}=0
$$

where $\eta$ is the overpotential and $\kappa^{\text {eff }}$ the effective ionic conductivity.

For sake of simplicity, a one-step mechanism is assumed in order to describe kinetic processes at the GDE. As an example, we can consider the simplified single 4-electron step 
mechanism, which is often assumed for the ORR mechanism in acidic and alkaline media. For such an electrochemical reaction involving two reacting species and occurring at the catalyst surface in the active layer, the current density $\mathrm{j}_{\mathrm{f}}$ per unit of catalyst surface area is given by:

$$
\mathrm{j}_{\mathrm{f}}=\mathrm{j}_{\mathrm{o}}\left[\exp \left(\frac{\alpha_{\mathrm{o}} \mathrm{F}}{\mathrm{RT}} \eta\right) \frac{\left[\mathrm{X}_{1}\right]}{\left[\mathrm{X}_{1}\right]_{0}}-\exp \left(\frac{-\alpha_{\mathrm{r}} \mathrm{F}}{\mathrm{RT}} \eta\right) \frac{\left[\mathrm{X}_{2}\right]}{\left[\mathrm{X}_{2}\right]_{0}}\right]
$$

Table 4 summarizes the parameters used for simulation.

Figure 22 presents the theoretical influence of the catalyst layer properties on the ac response. An increase of the catalyst loading (i.e. larger catalyst layer) enhances the polarization resistance of the GDE active layer. Conversely, better performances are obtained when considering a thinner active layer i.e. using smaller catalyst particles for example. This means that smaller catalyst layer allows better catalyst utilization.

Previous published results [94] highlighted the influence of catalyst gradients on PEMFC performances. The catalyst utilization efficiency depends on the diffusion and ionic ohmic drop limitations. For a porous active layer, performances are improved when the catalyst particles are located close to the active layer | membrane interface. Conversely, for a non-porous active layer, best performances are obtained when the catalyst particles are located close to the gas diffusion layer. These results show that the optimal catalyst utilization is observed with a thin active layer improving the catalyst access.

Ac response of the gas diffusion layer

Experimental impedance spectra exhibit a large capacitive loop in the Nyquist plane at low frequency $(1-10 \mathrm{~Hz})$ but it is intimately intertwined with capacitive arcs which are created by charge-transfer, double layer capacitance and mass-transport limitations within the active layer [91]. These results demonstrate that slow oxygen diffusion in the diffusion layer is a major concern, especially with non-optimized diffusion layers. Among the various microstructural parameters, the gas diffusion layer porosity plays an important role on the gas access to the triple phase boundary.

The Stefan-Maxwell equations allow us to describe diffusion of gaseous species in the GDL. Based on this description of the GDE, the solution is obtained from the mass-balance equation within the gas diffusion layer:

$$
\varepsilon^{\mathrm{GDL}} \mathrm{c}_{\mathrm{T}} \frac{\partial \mathrm{x}_{\mathrm{i}}}{\partial \mathrm{t}}=-\frac{\partial \mathrm{N}_{\mathrm{i}}}{\partial \mathrm{x}}
$$

where $\varepsilon^{\mathrm{GDL}}$ is the porosity and $\mathrm{N}$ the flux. The fluxes within the GDL are governed by the Stefan-Maxwell equation for multi-component diffusion: 


$$
\mathrm{c}_{\mathrm{T}} \frac{\mathrm{dx}_{\mathrm{i}}}{\mathrm{dx}}=\sum_{\mathrm{j} \neq \mathrm{i}} \frac{\mathrm{x}_{\mathrm{i}} \mathrm{N}_{\mathrm{j}}-\mathrm{x}_{\mathrm{j}} \mathrm{N}_{\mathrm{i}}}{\mathrm{D}_{\mathrm{i} j}^{\mathrm{eff}, \mathrm{GDL}}} \text { and } \quad \sum_{i} x_{i}=1
$$

where $D_{i j}$ are the binary diffusion coefficients.

Figure 23 presents simulated impedance diagrams of Gas Diffusion Electrode varying the gas diffusion layer porosity. Simulations were performed by using a previous published model [91].

According to classical models of gas diffusion electrodes, processes characteristic of oxygen diffusion within both gas diffusion and active layers may appear in the impedance spectra. At high current densities, theoretical approaches predict that these mass-transport processes should split the electrode impedance into three arcs corresponding to kinetics, diffusion in agglomerates and diffusion in the GDL. None of these arcs can be seen separately in the experimental impedance spectra due to a masking effect of the large value of the double layer capacitance at the electrode/electrolyte interface. In this theoretical case, one high and one moderate frequency semi-circle related to charge transfer and oxygen diffusion within the agglomerates, respectively, are observed and at low frequency a restricted Warburg impedance, due to $\mathrm{O}_{2}$ diffusion in the GDL, is also predicted. This last contribution is strongly affected by the porosity of the gas diffusion layer. It is well-known that the gas diffusion layer properties have to avoid water flooding the gas pores. So the presence of liquid water on the pore walls may reduce the gas diffusion porosity available for gas transport.

\section{II.4 Optimization of the Membrane-Electrode Assembly}

The development of the elementary components (membranes, catalysts) is of course necessary but not sufficient for optimizing the fuel cell electrical performance. The improvement of the membrane electrode assembly, of the cell assembling and also the determination of the best configuration of the cell working parameters (gas temperature, hydration, pressure and flow of reactants, and operating cell temperature) [95] may have a great influence on the cell electrical response.

In order to improve the Membrane Electrode Assembly performance, hot pressing of electrodes against a membrane is often carried out. Such a simple method for the MEA fabrication allows obtaining a good interface between the protonic membrane and the electrode active layers. The hot pressing method consists in thermo-welding two Nafioncontaining gas diffusion electrodes against a Nafion ${ }^{\circledR}$ membrane, under some experimental conditions. However, the physical phenomena relative to such process are not yet well known. The structure of MEAs can dramatically vary during the hot pressing process due to relatively 
high temperatures (from $100^{\circ} \mathrm{C}$ to $160^{\circ} \mathrm{C}$ ) and pressures (20 to $100 \mathrm{~kg} \mathrm{~cm}^{-2}$ ) [96], which can provoke some irreversible losses in the fuel cell performance. Several works were focused on the optimization of the hot pressure procedure [86, 97, 98], but the question remains still open.

However, it was clearly shown by Le Ninivin et al. that hot pressing a Nafioncontaining electrodes against a Nafion ${ }^{\circledR} 117$ membrane at $130^{\circ} \mathrm{C}$ under $35 \mathrm{~kg} \mathrm{~cm}^{-2}$ for 3 min led to improve the DMFC performance by a factor 3 [99]. Moreover, the determination of the optimal ionomer content in the electrodes is also an important factor for improving the fuel cell performance. For example, recent works indicated that the content of the Nafion ${ }^{\circledR}$ ionomer in the cathode catalyst-layer of a PEMFC, made by the "decal" hot pressing method, have an important effect on performance within the entire region of polarization curves (i.e. kinetics, ohmic, and mass-transport regions) as well as on the electrode structure. The authors determined an optimized Nafion ${ }^{\circledR}$ content in a range of $27 \pm 6 \mathrm{wt} \%$ for a cathodic E-TEK $20 \%$ $\mathrm{Pt}_{3} \mathrm{Cr} / \mathrm{C}$ catalyst with a loading of $0.20 \mathrm{mg}_{\mathrm{Pt}} \mathrm{cm}^{-2}$ [100].

Assembling cells in series is also a delicate procedure, which has a very important influence on the stack performance. Special attention has to be paid for the correct assembling of fuel cells, in particular, for the choice of the bolt torque that clamps the elementary cells together. The importance of this factor has been discussed by Lee et al. [101]. A correct choice for the bolt torque $(8 \mathrm{Nm})$ allows obtaining well reproducible results for each type of MEA used in our experiments as it was showed in previous works $[102,103]$.

Fuel Cell experiments were carried out with a single PEM fuel cell (surface area of 5 $\mathrm{cm} \times 5 \mathrm{~cm}$ ). The beneficial effect of the cell assembling procedure is confirmed in Figure 24, where excellent reproducible cell performance of almost $1.3 \mathrm{~W} \mathrm{~cm}$-2 has been recorded with a MEA fabricated with Pt/C catalysts synthesized via the Bönnemann colloidal method as described in section II.2. Electrodes (platinum loading of $0.35 \mathrm{mg}_{\mathrm{Pt}} \mathrm{cm}^{-2}$ in both electrodes) are pressed against a Nafion ${ }^{\circledR} 112$ membrane. Before the development of optimized procedure of cell assembling, only $0.5 \mathrm{~W} \mathrm{~cm}{ }^{-2}$ could be achieved with the same assembly [104, 105].

The MEA fabricated with electrodes prepared via the colloidal route (MEA 3 in Fig. 25) made possible to obtain a maximum power density higher than $1.2 \mathrm{~W} \mathrm{~cm}^{-2}$ with a total catalyst loading of $0.7 \mathrm{mg}_{\mathrm{Pt}} \mathrm{cm}^{-2}$, which corresponds to a specific power density of $1.7 \mathrm{~W}$ $\mathrm{mg}_{\mathrm{Pt}}{ }^{-1}$. This is more than two times higher than that obtained with a commercial MEA., e.g. from Fuel Cell Store (FCS) leading to $0.9 \mathrm{~W} \mathrm{~cm}^{-2}$ with a total platinum loading of $1.2 \mathrm{mg}_{\mathrm{Pt}}$ $\mathrm{cm}^{-2}$, corresponding to $0.75 \mathrm{~W} \mathrm{mg}_{\mathrm{Pt}^{-1}}$ as shown in Figure 25 .

The method of catalyst deposition by plasma sputtering was also used to further 
decrease the total catalyst amount down to $0.45 \mathrm{mg}_{\mathrm{Pt}} \mathrm{cm}^{-2}$ (cathode $0.35 \mathrm{mg}_{\mathrm{Pt}} \mathrm{cm}^{-2}$ by colloidal route / Nafion ${ }^{\circledR} 112$ / anode $0.1 \mathrm{mg}_{\mathrm{Pt}} \mathrm{cm}^{-2}$ from plasma sputtering process). Very interesting performances (close to $0.7 \mathrm{Wcm}^{-2}$ ) were obtained with such a low-platinum loading in MEA 1. This performance corresponds to a platinum utilization efficiency of $c a$. $1.6 \mathrm{~W} \mathrm{mg}_{\mathrm{Pt}}{ }^{-1}$, which is two times higher than that obtained with a commercial MEA from Fuel Cell Store (FCS). It is important to note that the decrease of the platinum loading is easier at the anode side than at the cathode side, as expected. Figure 26 illustrates this fact by comparing the cell performance obtained with the same MEAs as MEA 1, but with the low Pt loading electrode used either as anode or as cathode. When used as cathode the low Pt loading electrode leads to a dramatic decrease of the cell performance down to $0.45 \mathrm{~W} \mathrm{~cm}^{-2}$, which is two thirds of the maximum power density achieved with MEA 1 in Figure 25.

Then, considering that plasma sputtering is a clean and well-controlled procedure used by microelectronic manufacturers, it could be a good way for the fabrication of fuel cell electrodes and/or MEAs. Moreover, the powerful method of plasma sputtering let foresee the possibility of optimization of the platinum deposition (structure of the platinum thin film, particle size, depth profile, etc.) to decrease precious metal loading and to increase the fuel cell performance.

\section{CONCLUSIONS}

This paper has first discussed the effects of the properties of the MEA components on the electrical characteristics of a PEM elementary cell, then presented some experimental results obtained in the development of medium and high temperature membranes, in the achievement of low Pt loading of the electrode active layer by improved synthesis methods, and in the characterization and optimization of the MEA.

The most important key factor to decrease the volume, weight and cost of a PEMFC system is to increase the electrical characteristics of the MEA by improving the properties of its components (membrane, electrode catalysts, gas diffusion and active layers, etc.).

We have described here some novel membrane systems adapted for the medium temperature (cross-linked low equivalent weight PFSA, novel hypersulfonated polybenzimidazoles) and high temperature ranges (PBI-polyvinylphosphonic acid membranes), the latter being able to work up to $190{ }^{\circ} \mathrm{C}$ and leading to a power density of $0.5 \mathrm{~W} \mathrm{~cm}^{-2}$ at $160{ }^{\circ} \mathrm{C}$ under 3 bars abs with hydrogen and air.

Concerning the preparation of efficient electrocatalysts supported on a Vulcan XC72 carbon powder, the Bönnemann colloidal method and above all plasma sputtering allowed 
preparing bimetallic platinum-based electrocatalysts with a low Pt loading. In the case of plasma deposition of Pt nanoclusters, Pt loadings as low as $10 \mu \mathrm{g} \mathrm{cm}^{-2}$ were achieved, leading

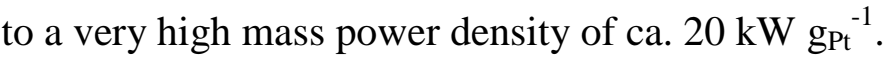

Finally characterization of the MEA electrical properties by Electrochemical Impedance Spectroscopy (EIS) based on a theoretical model of mass and charge transport inside the active and gas diffusion layers, together with the optimization of the operating parameters (cell temperature, humidity, flow rate and pressure) allowed obtaining electrical performance greater than $1.2 \mathrm{~W} \mathrm{~cm}^{-2}$ using an homemade MEAs with a rather low Pt loading.

In conclusion, it is important to develop new MEA components, based on a better localization of the catalyst layer in order to decrease the amount of noble metals, on new proton conducting membranes with higher conductivity and stability at higher temperatures and on the optimization of heat and mass transfer together the water management within the MEA.

\section{ACKNOWLEDGEMENTS}

The authors greatly acknowledge the French National Centre for Scientific Research (CNRS) for its continuous support to the GDR PACTE through the Institute of Chemistry and the Institute for Engineering and System Sciences of CNRS.

They would also acknowledge the Energy-Program of CNRS under the contract $\mathrm{n}^{\circ}$ PR08-1.5-3 (AMELI-0Pt) and the MID Innovation Agency of Dreux Town for their financial supports.

DJJ gratefully acknowledges financial support from the European Commission under FP6 Autobrane, contract nº20074 and FP6 IPHE-GENIE, contract nº 039016. 


\section{References}

1. W. R. Grove Phil. Mag. 1839, 14, 127.

2. W. R. Grove Phil. Mag. 1839, 15, 287.

3. J. O'M. Bockris, A. K. N. Reddy, Modern Electrochemistry, Plenum Press, New York, 1972, Vol. 2, p. 1141.

4. G. P. Sakellaropoulos in Advances in Catalysis, D. D. Eley, H. Pines, P. B. Weisz, Eds., Academic Press, New York, 1981, p. 218.

5. A. J. Appleby in Comprehensive Treatise of Electrochemistry, B. E. Conway, J. O'M. Bockris, E. Yeager, S. U. M. Khan, R. E. White, Eds., Plenum Press, New York, 1983, Vol. 7, pp. 173-239.

6. A.J Appleby and F.R. Foulkes, Fuel Cell Handbook, Van Nostrand Reinhold, New York, 1989, pp. 203-500.

7. K. Kordesch and G. Simader, Fuel Cells and their Applications, VCH, Weinheim, 1996.

8. P. Stevens, F. Novel-Catin, A. Hammou, C. Lamy and M. Cassir, Piles à combustible, Techniques de l'Ingénieur, traité Génie Electrique, D3 340 (2000), pp. 1-28.

9. W. Vielstich, A. Lamm and H. Geisteiger, Fuel Cells: Fundamental, Technology and Applications, Wiley, Chichester, 2003.

10. B. V. Tilak, R. S. Yeo, S. Srinivasan in Comprehensive Treatise of Electrochemistry, J. O'M. Bockris, B. E. Conway, E. Yeager, R. E. White, Eds., Plenum Press, New York, 1981, Vol. 3, pp. 39-122.

11. C. Lamy, J.-M. Léger J. Phys. IV 1994, C1-253.

12. C. Lamy, J.-M. Léger, S. Srinivasan in Modern Aspects of Electrochemistry, J. O'M. Bockris, B. E. Conway, R. E. White, Eds., Kluwer Academic / Plenum Publishers, New York, 2001, Vol. 34, pp. 53-118.

13. Fuel Cell Technology Handbook., edited by Gregor Hoogers, CRC Pres LLC, Boca Raton, Florida, 2003.

14. M. R. Tarasevich, A. Sadkowski, E. Yeager in Comprehensive Treatise of Electrochemistry, B. E. Conway, J. O'M. Bockris, E. Yeager, S. U. M. Khan, R. E. White, Eds., Plenum Press, New York, 1983, Vol. 7, pp. 301-398.

15. T. R. Ralph, M. P. Hogarth, Platinum Metals Rev. 2002, 46, 3; 146.

16. K. Prater, J. Power Sources, 29 (1990) 239.

17. C. Lamy, C. Coutanceau, J.-M. Léger, "The Direct Ethanol Fuel Cell: a challenge to convert Bioethanol cleanly into electric energy", in "Catalysis for Sustainable Energy 
Production", edited by P. Barbaro and C. Bianchini, Wiley-VCH, Weinheim, 2009, Chap.1, pp. 3-46.

18. C. Lim, C.Y. Wang, Electrochim. Acta 49 (2004) 4149.

19. A. S. Aricò, A. Di Blasi, G. Brunaccini, F. Sergi, G. Dispenza, L. Andaloro, M. Ferraro, V. Antonucci, P. Asher, S. Buche, D. Fongalland, G. A. Hards, J. D. B. Sharman, A. Bayer, G. Heinz, N. Zandonà, R. Zuber, M. Gebert, M. Corasaniti, A. Ghielmi, D. J. Jones, Fuel Cells 10 (2010) 1013.

20. H. R. Gao, Y. M. Zhang, B. Bauer, D. J. Jones, J. Rozière, IPHE-GENIE, An international partnership for the generation of novel ionomer membranes, Final Report, 2009.

21. Y. M. Zhang, L. Li, J. K. Tang, B. Bauer, W. Zhang, H. R. Gao, M. Taillades-Jacquin, D. J. Jones, J. Rozière, N. Lebedeva, R. K. A. M. Mallant, ECS Transactions 25 (2009) 1469.

22. H. R. Gao, PhD Thesis, University of Montpellier 2 (France), 2010.

23. J. Rozière, D. J. Jones, Annu. Rev. Mater. Res. 33 (2003) 503.

24. L. Gubler, S. A. Gürsel, G. G. Scherer, Fuel Cells 3 (2005) 317.

25. Y. S. Kim, M. A. Hickner, L. Dong, B. S. Pivovar, J. E. McGrath, J. Membr. Sci. 243 (2004) 317.

26. B. Bauer, D. J. Jones, J. Rozière, L. Tchicaya, G. Alberti, M. Casciola, L. Massinelli, A. Peraio, S. Besse, E. Rammuni, J. New Mater. Electrochem. Syst. 3 (2000) 93.

27. J. Peron, E. Ruiz, D. Jones, J. Rozière, J. Membr. Sci. 314 (2008) 247.

28. C. Marestin, G. Gebel, O. Diat, R. Mercier, Adv. Polym. Sci. 216 (2008) 185.

29. S. Subianto, D. J. Jones, J. Rozière, J. Membr. Sci., manuscript in preparation.

30. F. Ng, D. J. Jones, J. Rozière, M. J. Jeske, M. J. Schuster, B. Bauer, J. Membr. Sci. 362 (2010) 184.

31. D. J. Jones, J. Rozière, in: Encyclopedia of Electrochemical Power Sources, C. D. J. Garche, P. Moseley, B. Scrosati, Z. Ogumi, D. Rand, (Ed.), Elsevier, Amsterdam, Vol. 2, 2009, pp. 667-679.

32. Q. F. Li, J. O. Jensen, R. Savinell, N. J. Bjerrum, Prog. Polymer Sci. 34 (2009) 449.

33. H. Steininger, M. Schuster, K. D. Kreuer, J. Maier, Solid State Ionics 177 (2006) 2457.

34. J. Parvole, P. Jannasch, J. Mater. Chem. 18 (2008) 5547.

35. Y. Nedellec, M. Dupont, I. Kundler, J. Belack, D. J. Jones, J. Rozière, Progress MEA 2010, La Grande Motte, 2010, Proceedings p. 142.

36. B. Schubert, H. Tributsch, N. Alonso-Vante, A. Perrin, J. Catal. 112(1988) $384 .$. 
37. B. Schubert, N. Alonso-Vante, E. Gocke, H. Tributsch, Ber. Bunseng. Phys. Chem. 92 (1988) 1279.

38. N. Alonso-Vante, H. Tributsch, Nature 323 (1996) 431.

39. T.J. Schmidt, U.A. Paulus, H.A. Gasteiger, N. Alonso-Vante, R.J. Behm, J. Electrochem. Soc. 147 (2000) 2620.

40. R. Jiang, D. Chu, J. Electrochem. Soc. 147 (2000) 4605.

41. P. Convert, C. Coutanceau, P. Crouigneau, F. Gloaguen, C. Lamy, J. Appl. Electrochem. 31 (2001).

42. S. Baranton, C. Coutanceau, J.-M. Léger, C. Roux, P. Capron, Electrochimica Acta 51 (2005) 517.

43. S. Baranton, C. Coutanceau, C. Roux, F. Hahn, J.-M. Léger, J. Electroanal. Chem. 577 (2005) 223.

44. S. Baranton, C. Coutanceau, E. Garnier, J.-M. Léger, J. Electroanal. Chem. 590 (2006) 100.

45. K. Kinoshita, Electrochemical Oxygen Technology, Wiley, New York, 1992, p. 46.

46. P. Brault, S. Roualdès, A. Caillard, A.-L. Thomann, J. Mathias, J. Durand, C. Coutanceau, J.-M. Léger, C. Charles, R. Boswell, Eur. Phys. J. Appl. Phys. 34 (2006) 151.

47. M.T. Paffet, J.G. Beery, S. Gottesfeld, J. Electrochem. Soc. 135 (1988) 1431.

48. B.C. Beard, P.N. Ross, J. Electrochem. Soc. 137 (1990) 3368.

49. T. Toda, H. Igarashi, M. Watanabe, J. Electroanal. Chem. 460 (1999) 258.

50. N. Neergat, A. Shukla, K.S. Gandhi, J. Appl. Electrochem. 31 (2001) 373.

51. T. Toda, H. Igarashi, H. Ushida, M. Watanabe, J. Electrochem. Soc. 146 (1999) 3750.

52. R.C. Koffi, C. Coutanceau, E. Garnier, J.-M. Léger, C. Lamy, Electrochim. Acta 50 (2005) 4117.

53. C. Grolleau, C. Coutanceaua, F. Pierre, J.-M. Léger, J. Power Sources 195 (2010) 1569.

54. C. Lamy, A. Lima, V. LeRhun, F. Delime, C. Coutanceau, J-M. Léger, J. Power Sources, 105, (2002) 283.

55. C. Coutanceau, A. Rakotondrainibe, A. Lima, E. Garnier, S. Pronier, J. M. Léger, C. Lamy, J. Appl. Electrochem. 34 (2004) 61.

56. F. Vigier, C. Coutanceau, A Perrard, E. M. Belgsir, C. Lamy, J. Appl. Electrochem. 34, (2004) 439 - 446.

57. 24- C. Lamy, S. Rousseau, E. M. Belgsir, C. Coutanceau, J. -M. Léger, Electrochim. Acta 49 (2004) 3901. 
58. H. Bönneman,W. Brijoux, R. Brinkmann, E. Dinjus, T. Joussen, B. Korall, Angew. Chem. Int. Engl. 30 (1991) 1312.

59. H. Bönnemann, W. Brijoux, R. Brinkmann, R. Fretzen, T. Joussen, R. Köppler, B. Korall, P. Neiteler, J. Richter, J. Mol. Catal. 86 (1994) 129.

60. C. Grolleau, C. Coutanceau, F. Pierre, J.M. Leger. Electrochim. Acta. 53 (2008) 7157.

61. L. Dubau, C. Coutanceau, E. Garnier, J. -M. Léger, C. Lamy, J. Appl. Electrochem. 33 (2003) 419.

62. S. Rousseau, C. Coutanceau, C. Lamy, J.-M. Léger, J. Power Sources 158 (2006) 18.

63. P. Waszczuk, J. Solla-Gullon, H.-S. Kim, Y-Y. Tong, V. Montiel, A. Aldaz, A. Wieckowski, J. Catal. 203 (2001) 1.

64. S. Koh, P. Strasser, J. Am. Soc. 129 (2007) 12624.

65. E. Antolini, J.R.C. Salgado, R.M. da Silva, E.R. Gonzalez, Materials Chemistry and Physics 101-2 (2007) 395.

66. P. Yu, M. Pemberton, P. Plasse. J. Power Sources 144 (2005) 11.

67. S. Litster and G. McLean, J. Power Sources 130 (2004) 61.

68. T. H. Yang, Y. G. Yoon, C. S. Kim, S. H., K. H. Yoon, J. Power Sources 106 (2002) 328.

69. A. T. Haug, R. E. White, J. W. Weidner, W. Huang, S. Shi, T. Stoner, N. Rana, J. Electrochem. Soc. 149 (2002) A280.

70. A. T. Haug, R. E. White, J. W. Weidner, W. Huang, J. Electrochem. Soc. 149 (2002) A862.

71. A. T. Haug, R. E. White, J. W. Weidner, W. Huang, S. Shi, N. Rana, S. Grunow, T. Stoner J. Electrochem. Soc. 149 (2002) A868.

72. S. Y. Cha and W. M. Lee, J. Electrochem. Soc. 146 (1999) 4055.

73. S. Hira, J. Kim, S. Srinivasan, Electrochim. Acta 42 (1997)1587.

74. S. Mukerjee, S. Srinivasan, A. J. Appleby Electrochim. Acta 38 (1993) 1661.

75. P. Brault, A. Caillard, A. L. Thomann, J. Mathias, C. Charles, R. W. Boswell, S. Escribano, J. Durand, T. Sauvage, J. Phys. D 37 (2004) 3419.

76. A. Caillard, P. Brault, J. Mathias, C. Charles, R. Boswell, T. Sauvage, Surf. Coatings Technol. 200 (2005) 391.

77. H. Rabat, P. Brault, Fuel Cells 8 (2008) 81.

78. H. Rabat, C. Andreazza, P. Brault, A. Caillard, F. Béguin, C. Charles, R. Boswell, Carbon 47 (2009) 209.

79. A. Caillard, C. Charles, R. Boswell, P. Brault, C. Coutanceau, Appl. Phys. Lett. 90 (2007) 223119. 
80. A. Caillard, C. Charles, R. Boswell, P. Brault, Nanotechnology 18 (2007) 305603.

81. M. Cavarroc, A. Ennadjaoui, M. Mougenot, P. Brault, R. Escalier, Y. Tessier, J. Durand, S. Roualdès, T. Sauvage, C. Coutanceau, Electrochem. Comm. 11 (2009) 859.

82. S. Martin, P.L. Garcia-Ybarra, J.L. Castillo, Int. J. Hydrogen Energy 35 (2010) 10446.

83. E. Antolini, L. Giorgi, A. Pozio, E. Passalacqua, J. Power Sources 77 (1999) 136.

84. G. Sasikumar, J.W. Ihm, H. Ryu, J. Power Sources 132 (2004) 11.

85. A. Caillard, C. Coutanceau, P. Brault, J. Mathias, J.-M. Léger, J. Power Sources 162 (2006) 66.

86. J. Perez, E. R. Gonzales, E. A. Ticianelli, Electrochim. Acta 44 (1998) 1329.

87. M. Eikerling, A.A. Kornyshev, J. Electroanal. Chem. 475 (1999) 107.

88. O. Antoine, Y. Bultel, R. Durand, J. Electroanal. Chem. 499 (2001) 85.

89. Q. Guo, R.E. White, J. Electrochem. Soc. 151(4) (2004) E133.

90. T.E. Springer, T.A. Zawodzinski, S. Gottesfeld, J. Electrochem. Soc. 138 (1991) 2334.

91. Y. Bultel, K. Wiezell, F. Jaouen, P. Ozil, G. Lindbergh, Electrochim. Acta 51 (2005) 474.

92. M. Keddam, C. Rakotomavo, H. Takenouti, J. Appl. Electrochem 14 (1984) 437.

93. Y. Bultel, L. Genies, O. Antoine, P. Ozil and R. Durand, J. Electroanal. Chem. 527 (2002) 143.

94. O. Antoine, Y. Bultel, P. Ozil, R. Durand, Electrochim. Acta 45 (2000) 4493.

95. J.-J. A. Kadjo, P. Brault, A. Caillard, C. Coutanceau, J.-P. Garnier, S. Martemianov, J. Power Sources 72 (2007) 613

96. A. Therdthianwong, P. Manomayidthikarn, S. Therdthianwong, Energy 32 (2007) 2401.

97. B. Nakrumpai, K. Pruksathorn, P. Piumsomboon, Korean J. Chem. Eng. 2 (2006) 570..

98. J. Zhang, G. Yin, Z. Wang, Q. Lai, K. Cai, J. Power Sources 165 (2007) 73.

99. C. Le Ninivin, A. Balland-Longeau, D. Demattei, C. Coutanceau, C. Lamy, J.- M. Léger, J. Appl. Electrochem. 34 (2004) 1159.

100. J. Xie, F. Xu, D. L. Wood, K. L. More, T. A. Zawodzinski, W. H. Smith, Electrochim. Acta 55 (2010) 7404.

101. W.-K. Lee, C.-H. Ho, J.W.V. Zee, M. Murthy, J. Power Sources 84 (1999) 45.

102. D. Bograchev, M. Gueguen, J. C. Grandidier, S. Martemianov, J. Power Sources 180 (2008) 393.

103. D. Bograchev, M. Gueguen, J. C. Grandidier, S. Martemianov, Int. J. Hydrogen Energy 33 (2008) 5703. 
104. J.-J. A. Kadjo, J.-P. Garnier, S. Martemianov, J.-P. Maye, C. Coutanceau, S. Grigoriev, Proceedings of the French Heat Transfer Congress, Transfers in Heterogeneous Mediums, Peninsula of Giens, 2004, pp. 928-932.

105. J.-J. A. Kadjo, J.-P. Garnier, J.-P. Maye, F. Relot, S. Martemianov, Russian J. Electrochem. 42 (2006) 467. 


\section{Figure captions}

Figure 1: Hydrogen/oxygen fuel cell system.

Figure 2: Components of a Proton Exchange Membrane Elementary Cell.

Figure 3: Schematic representation of the Membrane-Electrode Assembly of a PEMFC.

Figure 4: Detailed scheme of a PEMFC system with its auxiliary and control equipments.

Figure 5a: Theoretical $E(j)$ electric characteristics of a fuel cell : influence of the membrane specific resistance $(\mathrm{Re}=\mathrm{e} / \sigma)$ on the $\mathrm{E}(\mathrm{j})$ curves: $(\diamond) \mathrm{j}_{\mathrm{o}}=10^{-8} \mathrm{~A} \mathrm{~cm}^{-2} ; \mathrm{R}_{\mathrm{e}}=0.15 \Omega \mathrm{cm}^{2}$; $\mathrm{j}_{1}=1.3 \mathrm{~A} \mathrm{~cm}^{-2} ;(\square) \quad \mathrm{j}_{\mathrm{o}}=10^{-8} \mathrm{~A} \mathrm{~cm}^{-2} ; \mathrm{R}_{\mathrm{e}}=0.30 \Omega \mathrm{cm}^{2} ; \mathrm{j}_{1}=1.2 \mathrm{~A} \mathrm{~cm}^{-2}$.

Figure 5b: Theoretical E(j) electric characteristics of a fuel cell : Influence of the catalytic properties of electrodes (exchange current density $\mathrm{j}_{\mathrm{o}}$ ) on the $\mathrm{E}(\mathrm{j})$ curves: $(\triangle) \mathrm{j}_{\mathrm{o}}=10^{-6} \mathrm{~A}$ $\mathrm{cm}^{-2} ; \mathrm{R}_{\mathrm{e}}=0.15 \Omega \mathrm{cm}^{2} ; \mathrm{j}_{1}=1.4 \mathrm{~A} \mathrm{~cm}^{-2} ;(\diamond) \quad \mathrm{j}_{\mathrm{o}}=10^{-8} \mathrm{~A} \mathrm{~cm}^{-2} ; \mathrm{R}_{\mathrm{e}}=0.15 \Omega \mathrm{cm}^{2} ; \mathrm{j}_{1}=$ $1.3 \mathrm{~A} \mathrm{~cm}^{-2}$.

Figure 5c: Theoretical $\mathrm{E}(\mathrm{j})$ electric characteristics of a fuel cell : Influence of the mass transfer limitations (limiting current density $\mathrm{j}_{1}$ ) on the $\mathrm{E}(\mathrm{j})$ curves: $(\triangle) \mathrm{j}_{\mathrm{o}}=10^{-6} \mathrm{~A} \mathrm{~cm}^{-2} ; \mathrm{R}_{\mathrm{e}}=0.15$ $\Omega \mathrm{cm}^{2} ; \mathrm{j}_{1}=1.4 \mathrm{~A} \mathrm{~cm}^{-2} ;(+) \quad \mathrm{j}_{\mathrm{o}}=10^{-6} \mathrm{~A} \mathrm{~cm}^{-2} ; \mathrm{R}_{\mathrm{e}}=0.10 \Omega \mathrm{cm}^{2} ; \mathrm{j}_{1}=2.2 \mathrm{~A} \mathrm{~cm}^{-2}$.

Figure 6: $\mathrm{E}(\mathrm{j})$ characteristics of a PEMFC elementary cell with different membranes : $(\mathbf{\Delta})$ Dow $(\mathrm{e}=125 \mu \mathrm{m}) ;(\mathrm{O})$ Nafion ${ }^{\circledR} 115(\mathrm{e}=125 \mu \mathrm{m}) ;(\Delta)$ Nafion $^{\circledR} 117(\mathrm{e}=175 \mu \mathrm{m}) ;$ After K. Prater (Ballard), J. Power Sources, 29 (1990) 239 [16].

Figure 7: Fuel cell characteristics of a DEFC recorded at $110^{\circ} \mathrm{C}$. Influence of the nature of the bimetallic anodic catalyst (30\% loading). Anode catalyst : $1.5 \mathrm{mg} . \mathrm{cm}^{-2}$; Cathode catalyst : 2 mg.cm ${ }^{-2}$ (40\% Pt/XC72 E-TEK); Membrane : Nafion ${ }^{\circledR} 117$; Ethanol concentration : $1 \mathrm{M}$; After C. Lamy et al, Chap.1, C. Bianchini et al. [17].

Figure 8: Cell voltage vs. current density curves for an $\mathrm{H}_{2} /$ air $\mathrm{FC}$ with MEAs using three different types of carbon cathode GDL $\left(80^{\circ} \mathrm{C}, 0.22 \mathrm{mg} \mathrm{cm}^{-2} \mathrm{Pt}\right.$ loading): (๑) microporous layer-coated and $30 \mathrm{wt} \%$ FEP-impregnated; (ロ) $30 \mathrm{wt} \%$ FEP-impregnated; (ム) $10 \mathrm{wt} \%$ FEP-impregnated; After C. Lim, C.Y. Wang, Electrochim. Acta 49 (2004) 4149-4156 [18].

Figure 9: Acid form of sulfonimide-bridged perfluorosulfonic ionomer.

Figure 10: Water uptake $(\%)$ at $25^{\circ} \mathrm{C}(\triangle)$ and $80^{\circ} \mathrm{C}(\boldsymbol{\Delta})$, and area dimensional change $(\%)$ at $25^{\circ} \mathrm{C}(\square)$ and $80^{\circ} \mathrm{C}(\boldsymbol{\square})$ in reference PFSA membrane, non-cross-linked sulfonamide and cross-linked (XL) sulfonimide forms prepared by thermal treatment at 200,240 and $270^{\circ} \mathrm{C}$.

Figure 11: Conductivity of sPBI-OPh sulfonated in a) $96 \% \mathrm{H}_{2} \mathrm{SO}_{4}$ b) $30 \%$ oleum at $25^{\circ} \mathrm{C}$ and $100 \%$ relative humidity, as a function of the IEC of the sulfonated polymer. In a), sulfonation occurs preferentially on the benzyl rings adjacent to ether linkages; in b) sulfonation also occurs on the Cardo group.

Figure 12: Cell voltage and power density as a function of current density (active surface area $45 \mathrm{~cm}^{2}$ ) of Celtec-V type MEAs based on PBI and poly(vinylphosphonic) acid, operated on hydrogen and air hydrated at $80 / 64^{\circ} \mathrm{C}$ respectively, under the temperature and pressure conditions shown (collaboration CNRS-ICGM - BASF Fuel Cell in FP6 Autobrane).

Figure 13: Deposition of colloidal particles on a carbon powder.

Figure 14: Characterization of a Pt catalyst prepared by the colloidal method.

Figure 15: Characterization of a $\mathrm{Pt}_{0.8} \mathrm{Ru}_{0.2} / \mathrm{C}$ bimetallic catalyst prepared by the Bönnemann 
colloidal method: (a) co-reduced catalyst ; 'b) co-deposited catalyst.

Figure 16: XRD patterns of different $\mathrm{PtM}(40 \mathrm{wt} \%) / \mathrm{XC} 72$ catalysts prepared by the Bönnemann method.

Figure 17: Voltammetric curves of the ORR at $\mathrm{Pt}_{3} \mathrm{M}(40 \mathrm{wt} \%) / \mathrm{C}$ binary catalysts $(\mathrm{M}=\mathrm{Co}, \mathrm{Fe}$, $\mathrm{Ni}$ ) in $\mathrm{O}_{2}$-saturated $\mathrm{H}_{2} \mathrm{SO}_{4}$ at $\mathrm{T}=20^{\circ} \mathrm{C}, \mathrm{v}=3 \mathrm{mV} \mathrm{s}^{-1}$ and $\Omega=2500 \mathrm{rpm}$.

Figure 18: PEMFC electrode deposition on a carbon diffusion layer. After H. Rabat, P. Brault, Fuel Cells 8, 81-86 (2008) [77] ; H. Rabat, C. Andreazza, P. Brault, A. Caillard, F. Béguin, C. Charles, R. Boswell, Carbon 47, 209-214 (2009) [78].

Figure 19: Depth distribution of platinum inside the C/Pt electrode (as measured by RBS).

Figure 20: Electrical performances of several PEMFC with plasma cathodes made with different $\mathrm{Pt}$ loadings; $\mathrm{H}_{2}$ and $\mathrm{O}_{2}$ at 4 bars; cell at $80^{\circ} \mathrm{C}$.

Figure 21: Fuel cell tests of a C-Pt co-deposited on an E-Tek diffusion layer [81].

Figure 22: Simulated impedance diagrams for a catalyst layer $(\eta=0.4 \mathrm{~V}):(\bigcirc) \gamma=50 \mathrm{~cm}^{2} \mathrm{~cm}^{-2}$ and $\mathrm{L}=5 \mu \mathrm{m} ;(\boldsymbol{\nabla}) \gamma=50 \mathrm{~cm}^{2} \mathrm{~cm}^{-2}$ and $\mathrm{L}=10 \mu \mathrm{m} ;(\boldsymbol{\Delta}) \gamma=100 \mathrm{~cm}^{2} \mathrm{~cm}^{-2}$ and $\mathrm{L}=20 \mu \mathrm{m}$.

Figure 23: Simulated impedance diagrams for a $\operatorname{GDE}\left(j=1 \mathrm{~A} \mathrm{~cm}^{-2}\right.$ and $\left.\mathrm{L}^{\mathrm{GDL}}=500 \mu \mathrm{m}\right)$ : $\varepsilon^{\mathrm{GDL}}=40 \% ;(\diamond) \varepsilon^{\mathrm{GDL}}=20 \%$.

Figure 24: Performance of a MEA fabricated with Pt/C catalysts synthesized by the colloidal route. Membrane: Nafion 112; Symmetric electrodes: $0.35 \mathrm{mg}_{\mathrm{Pt}} \mathrm{cm}^{-2}$; Pt loading $40 \mathrm{wt} \%$ $/ \mathrm{C}\left(\mathrm{T}_{\text {cell }}=\mathrm{T}_{\text {huma }}=70^{\circ} \mathrm{C}, \mathrm{T}_{\text {humc }}=25^{\circ} \mathrm{C}, \mathrm{H}_{2}\right.$ flow $=600 \mathrm{~mL} \mathrm{~min}^{-1}, \mathrm{O}_{2}$ flow $=300 \mathrm{~mL} \mathrm{~min}^{-1}$, $\mathrm{P}_{\mathrm{H}_{2}}=\mathrm{P}_{\mathrm{O}_{2}}=3$ bar).

Figure 25: Comparison between commercial and homemade MEAs. MEA 1: homemade anode via platinum plasma sputtering + homemade cathode via the colloidal route $(0.45$ $\mathrm{mg}_{\mathrm{Pt}_{\mathrm{t}}} \mathrm{cm}^{-2}$ total loading); MEA 2: commercial MEA from FCS $\left(1.2 \mathrm{mg}_{\mathrm{Pt}} \mathrm{cm}^{-2}\right.$ total loading); MEA 3 : homemade electrodes via the colloidal route $\left(0.7 \mathrm{mg}_{\mathrm{Pt}} \mathrm{cm}^{-2}\right.$ total loading). $\mathrm{T}_{\text {cell }}=85^{\circ} \mathrm{C} ; \mathrm{T}_{\text {huma }}=80^{\circ} \mathrm{C}, \mathrm{T}_{\text {humc }}=35^{\circ} \mathrm{C}, \mathrm{H}_{2}$ flow $=600 \mathrm{~mL} \mathrm{~min}^{-1}, \mathrm{O}_{2}$ flow $=300$ $\mathrm{mL} \min ^{-1}, \mathrm{P}_{\mathrm{H}_{2}}=\mathrm{P}_{\mathrm{O}_{2}}=2.3 \mathrm{bar}$

Figure 26: Performance of MEAs fabricated with Pt40wt\%/C electrodes synthesized by plasma sputtering $\left(0.1 \mathrm{mg}_{\mathrm{Pt}} \mathrm{cm}^{-2}\right)$ or by the colloidal route $\left(0.35 \mathrm{mg}_{\mathrm{Pt}} \mathrm{cm}^{-2}\right)$ and a Nafion 112 membrane. $\left(\mathrm{T}_{\text {cell }}=\mathrm{T}_{\text {huma }}=70^{\circ} \mathrm{C}, \mathrm{T}_{\text {humc }}=25^{\circ} \mathrm{C}, \mathrm{H}_{2}\right.$ flow $=600 \mathrm{~mL} \mathrm{~min}{ }^{-1}, \mathrm{O}_{2}$ flow $=$ $300 \mathrm{~mL} \mathrm{~min}{ }^{-1}, \mathrm{P}_{\mathrm{H}_{2}}=\mathrm{P}_{\mathrm{O}_{2}}=3$ bar). 
Table 1: Consequences of the electrical characteristics E(j) on the PEMFC stack cost (estimated cost of the MEA based on the actual cost of its constituents): example of an electrical vehicle with a power train FC stack of $63 \mathrm{~kW}$

\begin{tabular}{|c|c|c|c|c|c|c|}
\hline $\begin{array}{l}\text { Power } \\
\text { density / W } \\
\mathrm{cm}^{-2}\end{array}$ & $\begin{array}{l}\text { Electrode } \\
\text { surface } \\
\text { area } / \mathrm{m}^{2}\end{array}$ & $\begin{array}{l}\text { Membrane } \\
\operatorname{cost}^{(1)} / €\end{array}$ & $\begin{array}{l}\text { Platinum } \\
\text { metal } \\
\text { loading }{ }^{(2)} / \mathrm{g}\end{array}$ & $\begin{array}{l}\text { Platinum metal } \\
\left.\operatorname{cost}^{(3)}\right) / €\end{array}$ & $\begin{array}{l}\text { Total cost of the } \\
\text { stack MEA / } €\end{array}$ & $\begin{array}{l}\text { MEA cost } \\
\text { per } \mathrm{kW} / €\end{array}$ \\
\hline 0.175 & 36 & 14400 & 36 & 1800 & $\sqrt{16200}$ & 257 \\
\hline 0.28 & 22.5 & 9000 & 22.5 & 1125 & 10125 & 161 \\
\hline 0.63 & 10 & 4000 & 10 & 500 & 4500 & 71.4 \\
\hline 1.05 & 6 & 2400 & 6 & 300 & 2700 & 42.9 \\
\hline
\end{tabular}

- (1) based on a Nafion ${ }^{\circledR}$ membrane cost of $400 € / \mathrm{m}^{2}$

- (2) based on a platinum loading of $0.1 \mathrm{mg} / \mathrm{cm}^{2}$

- (3) based on a platinum cost of $50 € / \mathrm{g}$ 
Table 2: Mean particle sizes as determined by TEM and crystallographic structure as determined by XRD measurements of the different supported catalysts prepared by the Bönnemann method.

\begin{tabular}{|l|l|l|}
\hline Catalyst & $d_{\text {TEM }} / \mathbf{n m}$ & Crystallographic structure \\
\hline Pt/XC72 & 2.2 & Fcc \\
\hline Pt+Ru(80:20)/XC72 & 2.1 & Fcc Pt + hc Ru (in interaction) \\
\hline Pt-Ru(80:20)/XC72 & 1.9 & Fcc alloy \\
\hline Pt/XC72 + Ru/XC72 (80:20) & Pt(2.1)+Ru(1.5) & Fcc Pt + hc Ru \\
\hline Ru/XC72 & 1.5 & Hexagonal compact (hc) \\
\hline
\end{tabular}


Table 3: Bulk atomic composition as determined by EDX, mean particle sizes as determined by TEM and catalytic activity towards the ORR of the different $\mathrm{Pt}_{3} \mathrm{M} / \mathrm{XC} 72$ catalysts prepared by the Bönnemann method.

\begin{tabular}{|l|l|l|l|l|}
\hline Catalyst & \multicolumn{1}{|c|}{$\begin{array}{c}\text { Nominal } \\
\text { composition / at } \%\end{array}$} & $\begin{array}{c}\text { EDX composition } \\
/ \text { at } \%\end{array}$ & $\begin{array}{c}\mathbf{d}_{\mathrm{TEM}} / \\
\mathrm{nm}\end{array}$ & $\begin{array}{l}\mathbf{j}_{\mathrm{k}} \text { at } \mathbf{0 . 9 5} \mathrm{V} \text { for the ORR } \\
/ \mathrm{mA} \mathrm{cm}^{-2}\end{array}$ \\
\hline $\mathrm{Pt}$ & 100 & 100 & 2.5 & 0.82 \\
\hline $\mathrm{PtNi}$ & $75 / 25$ & $91 / 9$ & 2.0 & 1.09 \\
\hline PtFe & $75 / 25$ & $78 / 22$ & 2.5 & 1.11 \\
\hline PtCo & $75 / 25$ & $84 / 16$ & 2.0 & 1.68 \\
\hline
\end{tabular}




\begin{tabular}{|l|l|}
\hline Kinetic parameters & $\mathrm{j}_{0}=10^{-3} \mathrm{~A} \mathrm{~m}^{-2}, \alpha_{\mathrm{o}}=0.5, \alpha_{\mathrm{r}}=0.5$ \\
\hline Mass and charge transport parameters & $\mathrm{D}^{\mathrm{eff}}=10^{-9} \mathrm{~m}^{2} \mathrm{~s}^{-1}$ and $\kappa^{\mathrm{eff}}=0.01 \mathrm{~S} \mathrm{~m}^{-1}$ \\
\hline Double layer Capacitance & $\mathrm{C}_{\mathrm{dl}}=0.1 \mathrm{~F} \mathrm{~m}^{-2}$ \\
\hline
\end{tabular}


Electrode reactions (acid electrolyte) :

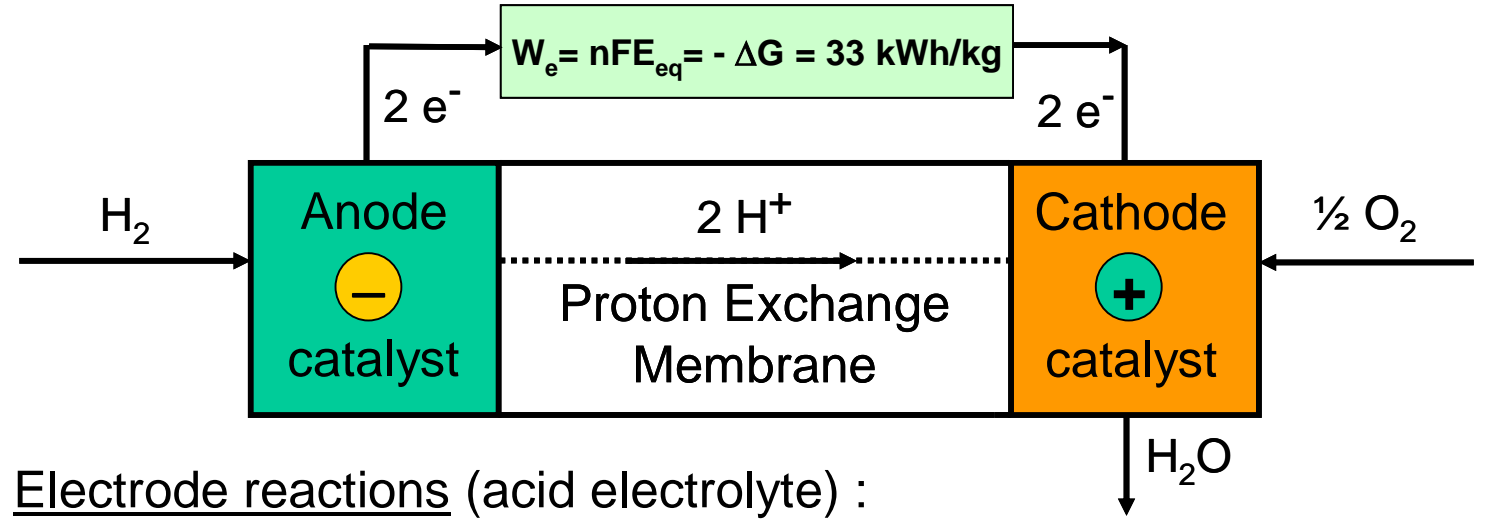

- Anode

$\mathrm{H}_{2} \longrightarrow 2 \mathrm{H}^{+}+2 \mathrm{e}^{-}$

- Cathode $1 / 2 \mathrm{O}_{2}+2 \mathrm{H}^{+}+2 \mathrm{e}^{-} \longrightarrow \mathrm{H}_{2} \mathrm{O}$

$\mathrm{H}_{2}+1 / 2 \mathrm{O}_{2} \rightarrow \mathrm{H}_{2} \mathrm{O}$ with $\Delta \mathrm{G}^{\circ}=-237 \mathrm{~kJ} / \mathrm{mole}$ and $\mathrm{E}_{\mathrm{eq}}=1.23 \mathrm{~V}$
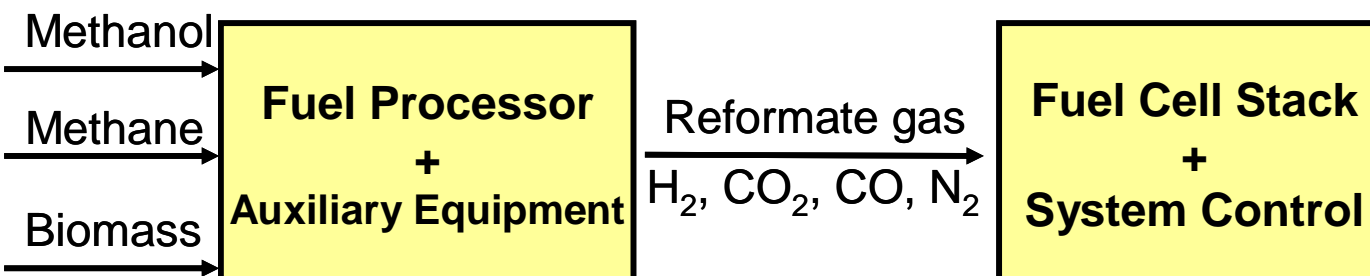

$\underset{\text { Electricity }}{\longrightarrow}$

Figure 1: Hydrogen/oxygen fuel cell system 


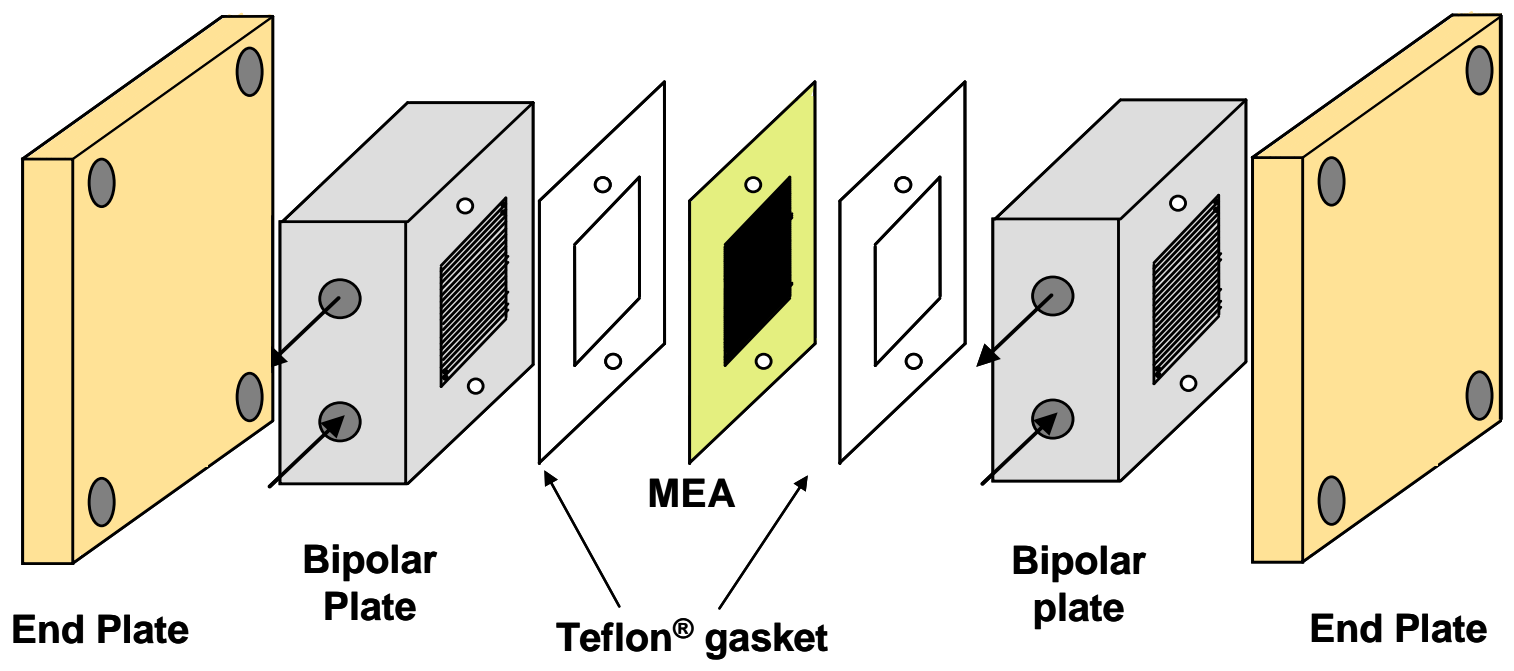

$\underline{\text { Figure 2: }}$ Components of a Proton Exchange Membrane Elementary Cell 


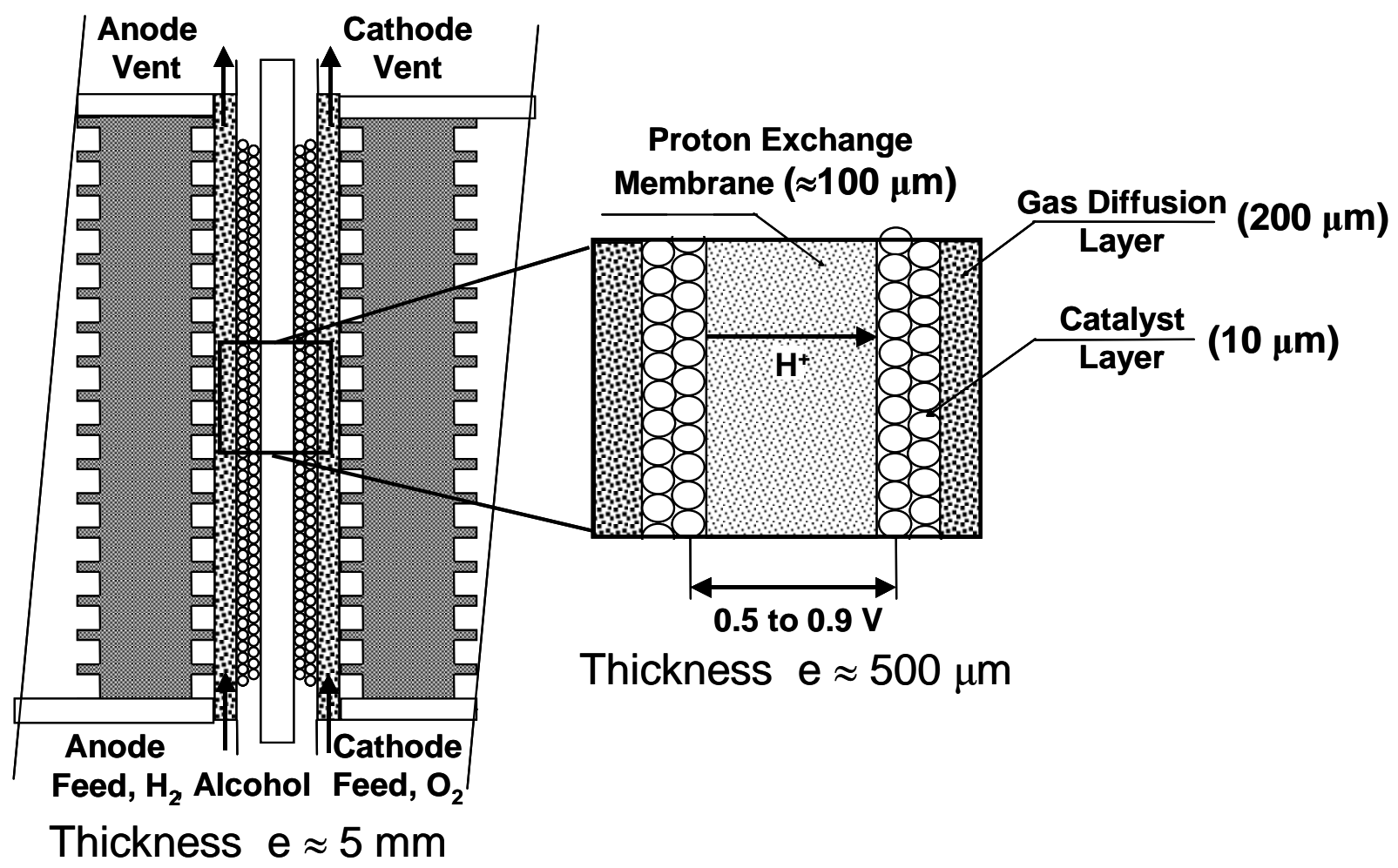

Figure 3: Schematic representation of the Membrane-Electrode Assembly of a PEMFC 


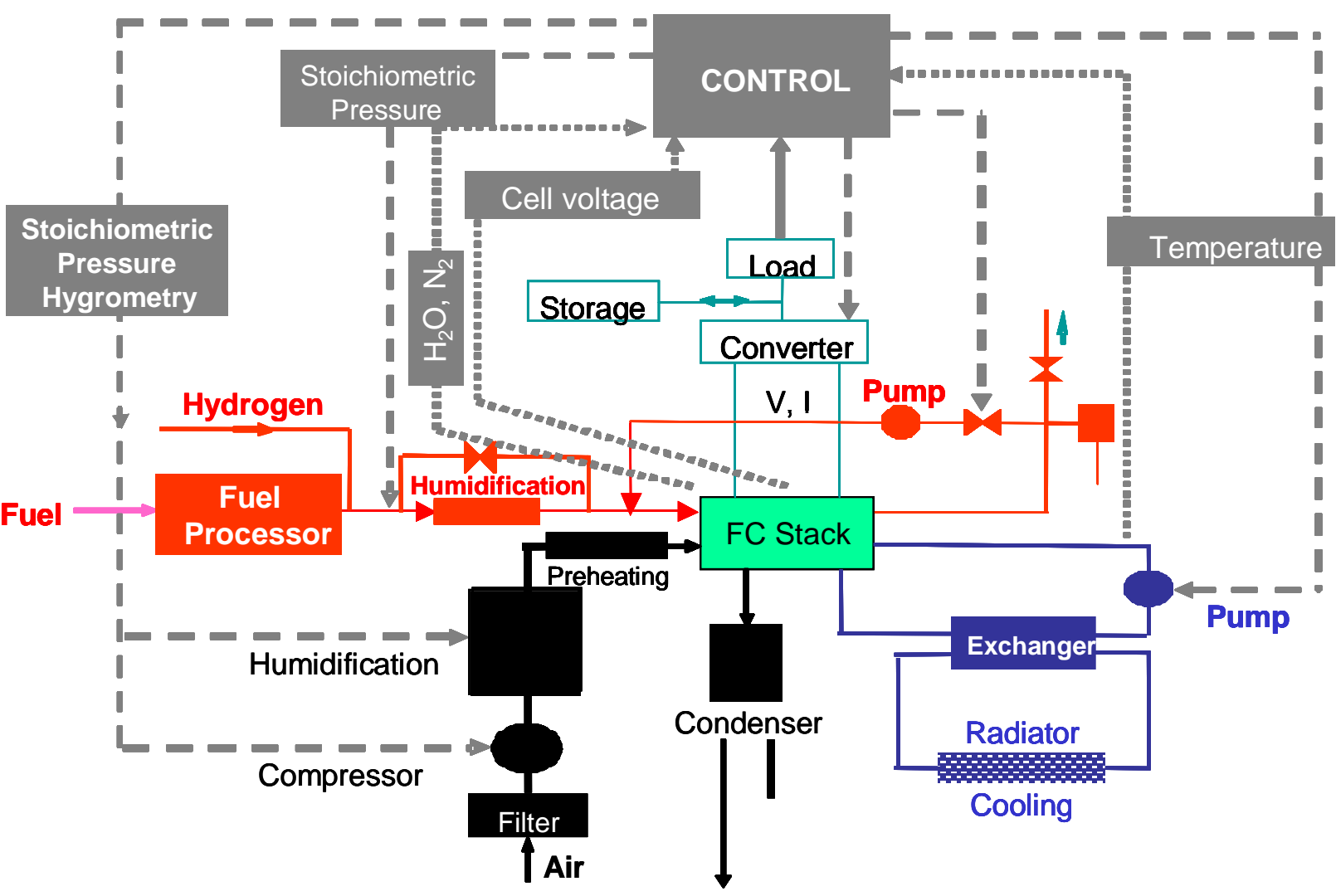

Figure 4: Detailed scheme of a PEMFC system with its auxiliary and control equipments. 


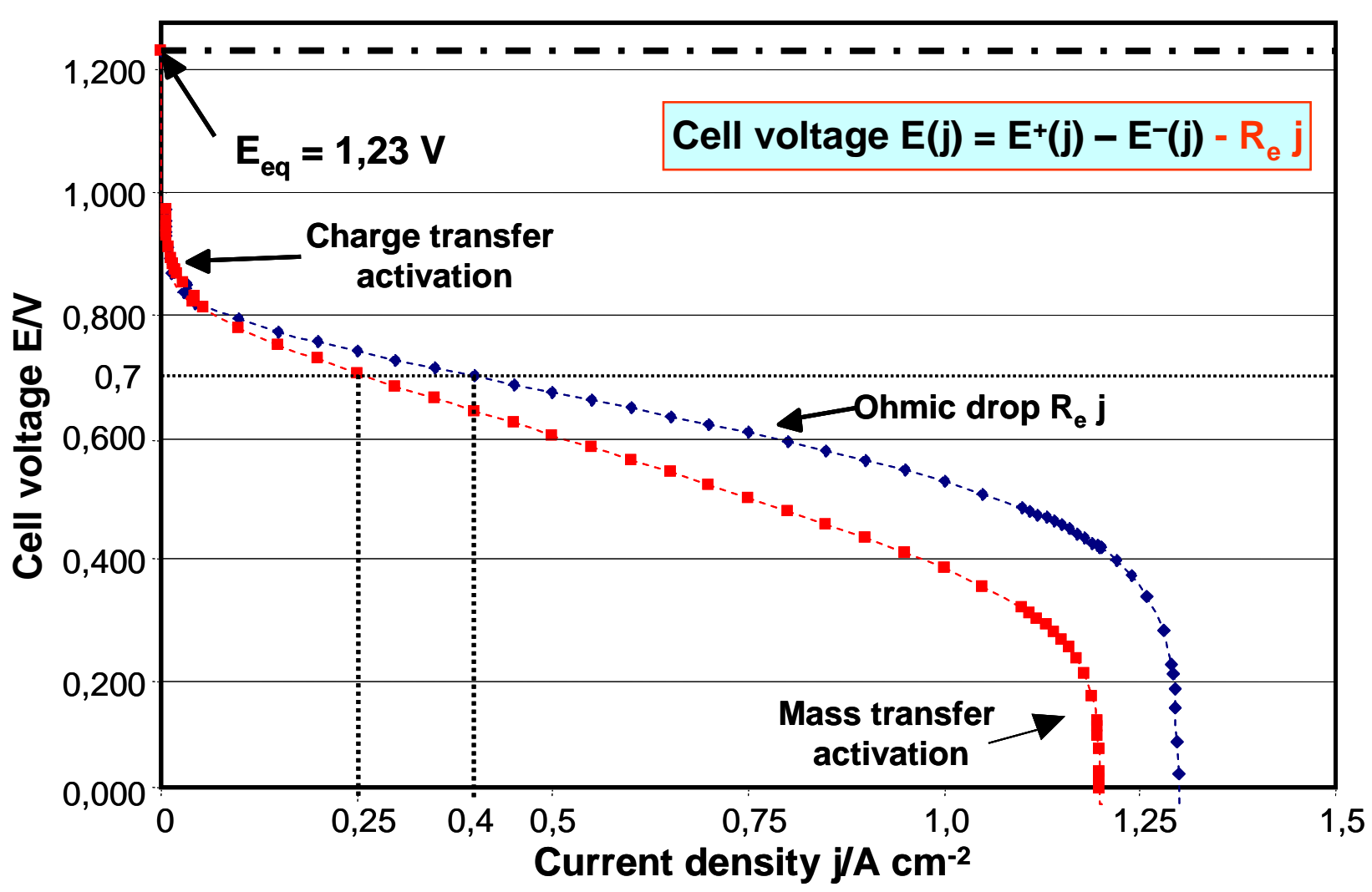

Figure 5a: Theoretical E(j) electric characteristics of a fuel cell : influence of the membrane specific resistance $(\mathrm{Re}=\mathrm{e} / \sigma)$ on the $\mathrm{E}(\mathrm{j})$ curves.

$(\diamond) \quad \mathrm{j}_{\mathrm{o}}=10^{-8} \mathrm{~A} \mathrm{~cm}^{-2} ; \mathrm{R}_{\mathrm{e}}=0.15 \Omega \mathrm{cm}^{2} ; \mathrm{j}_{1}=1.3 \mathrm{~A} \mathrm{~cm}^{-2}$

(घ) $\mathrm{j}_{\mathrm{o}}=10^{-8} \mathrm{~A} \mathrm{~cm}^{-2} ; \mathrm{R}_{\mathrm{e}}=0.30 \Omega \mathrm{cm}^{2} ; \mathrm{j}_{1}=1.2 \mathrm{~A} \mathrm{~cm}^{-2}$ 


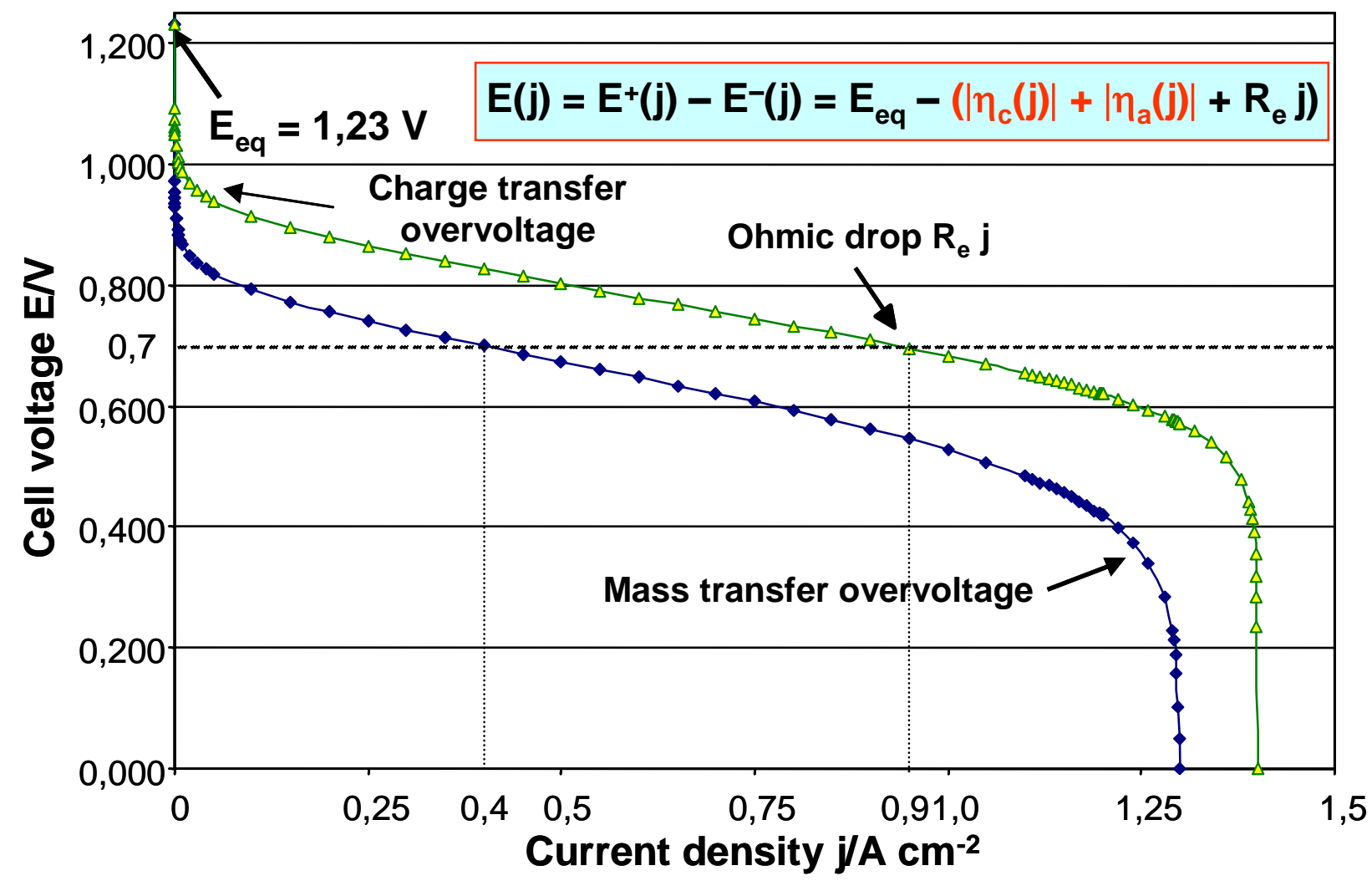

Figure 5b: Theoretical E(j) electric characteristics of a fuel cell : Influence of the catalytic properties of electrodes (exchange current density $\mathrm{j}_{\mathrm{o}}$ ) on the $E(\mathrm{j})$ curves.

$(\triangle) \quad j_{o}=10^{-6} \mathrm{~A} \mathrm{~cm}^{-2} ; R_{e}=0.15 \Omega \mathrm{cm}^{2} ; j_{1}=1.4 \mathrm{~A} \mathrm{~cm}^{-2}$

$(\diamond) \quad \mathrm{j}_{\mathrm{o}}=10^{-8} \mathrm{~A} \mathrm{~cm}^{-2} ; \mathrm{R}_{\mathrm{e}}=0.15 \Omega \mathrm{cm}^{2} ; \mathrm{j}_{1}=1.3 \mathrm{~A} \mathrm{~cm}^{-2}$ 


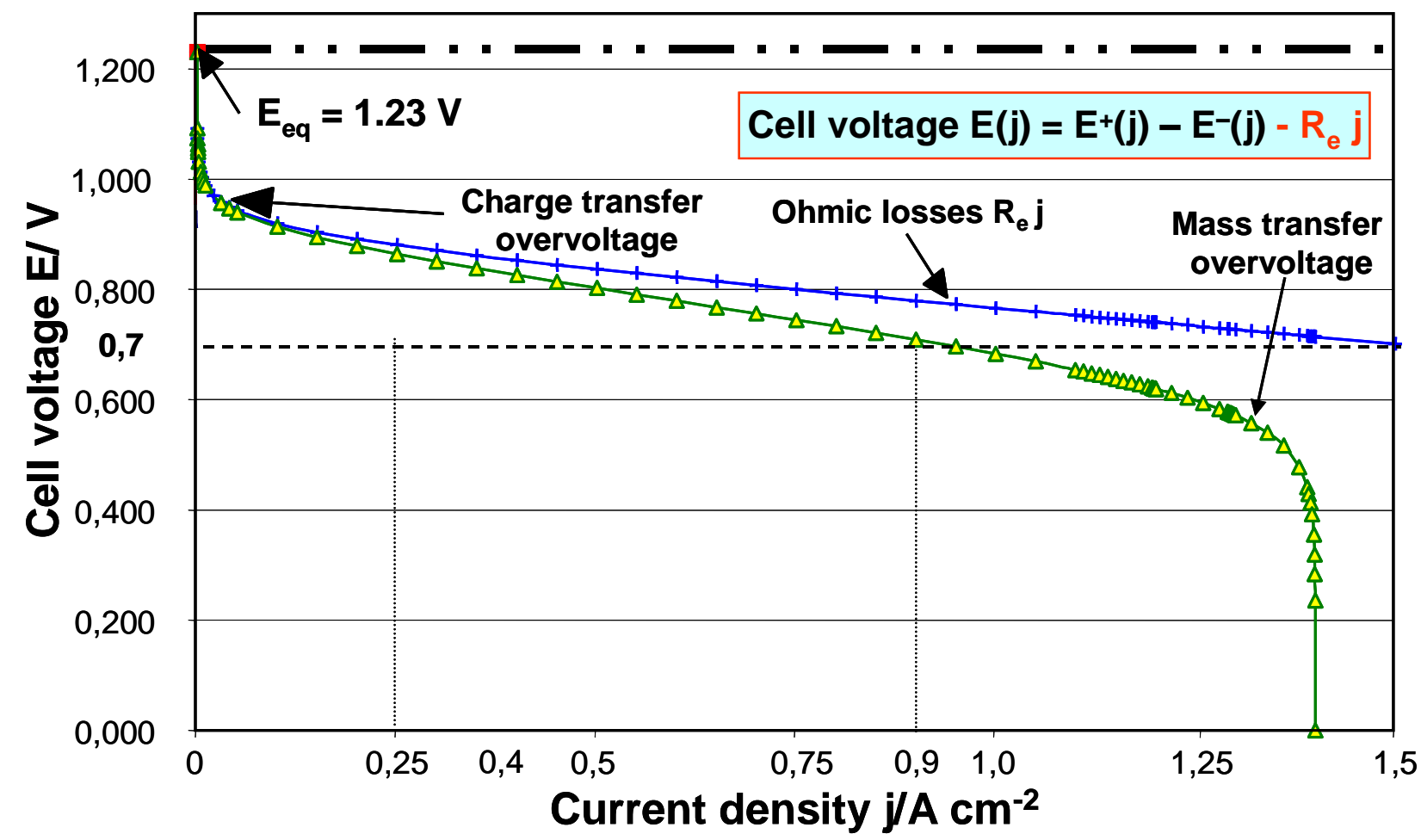

Figure 5c: Theoretical E(j) electric characteristics of a fuel cell : Influence of the mass transfer limitations (limiting current density $\mathrm{j}_{1}$ ) on the $\mathrm{E}(\mathrm{j})$ curves.
$(\triangle) \quad j_{\mathrm{o}}=10^{-6} \mathrm{~A} \mathrm{~cm}^{-2} ; \mathrm{R}_{\mathrm{e}}=0.15 \Omega \mathrm{cm}^{2} ; \mathrm{j}_{1}=1.4 \mathrm{~A} \mathrm{~cm}^{-2}$
(+) $\mathrm{j}_{\mathrm{o}}=10^{-6} \mathrm{~A} \mathrm{~cm}^{-2} ; \mathrm{R}_{\mathrm{e}}=0.10 \Omega \mathrm{cm}^{2} ; \mathrm{j}_{\mathrm{l}}=2.2 \mathrm{~A} \mathrm{~cm}^{-2}$ 


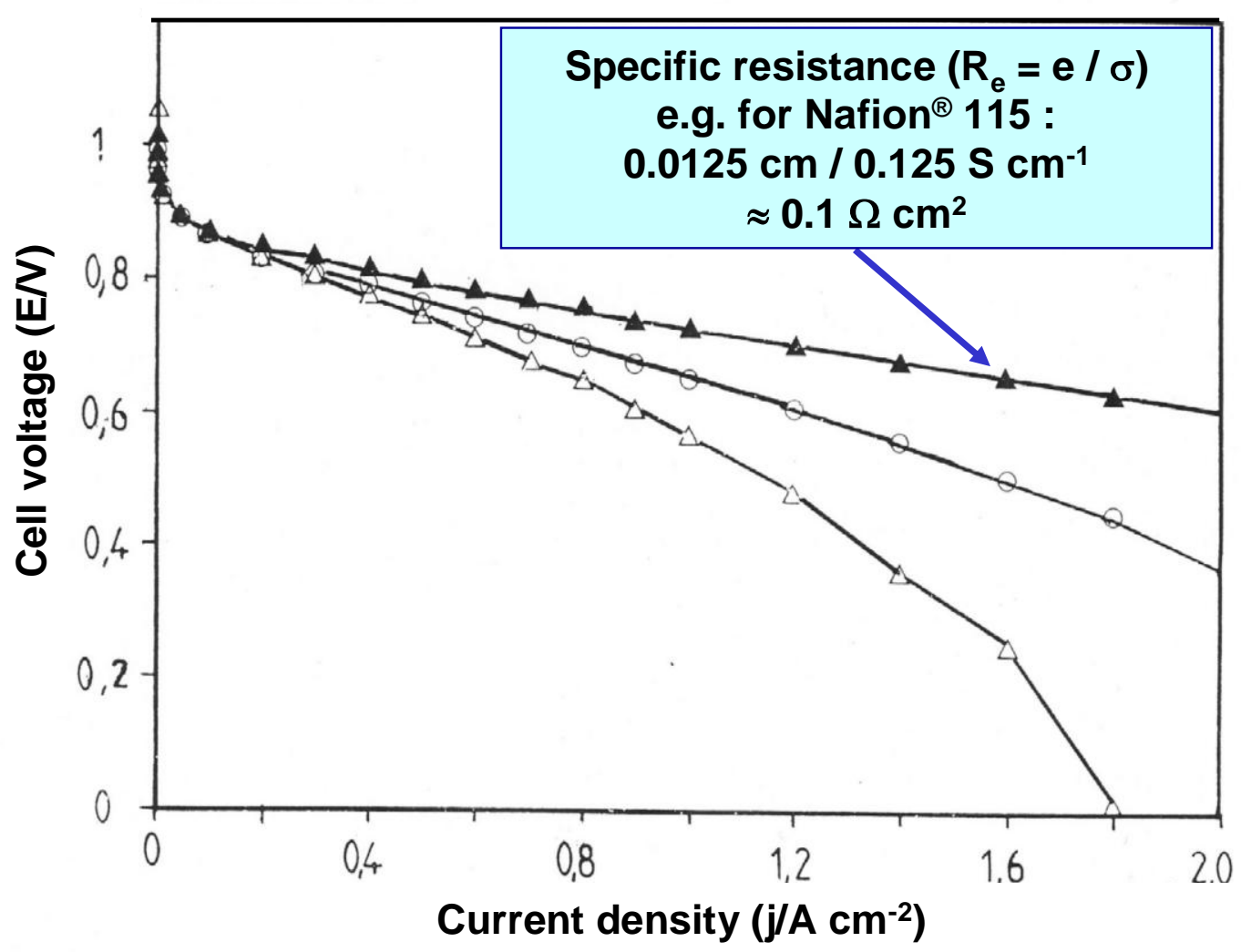

Figure 6: E(j) characteristics of a PEMFC elementary cell with different membranes :

(4) Dow $(\mathrm{e}=125 \mu \mathrm{m}) ;(\mathrm{O})$ Nafion ${ }^{\circledR} 115(\mathrm{e}=125 \mu \mathrm{m}) ;(\Delta)$ Nafion $^{\circledR} 117(\mathrm{e}=175 \mu \mathrm{m})$

After K. Prater (Ballard), J. Power Sources, 29 (1990) 239 


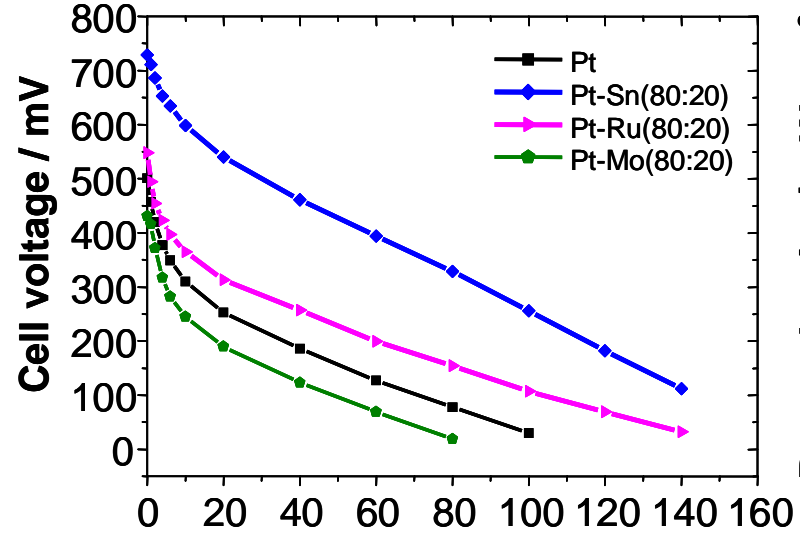

Current density / $\mathrm{mA} \mathrm{cm}^{-2}$ Polarization curves

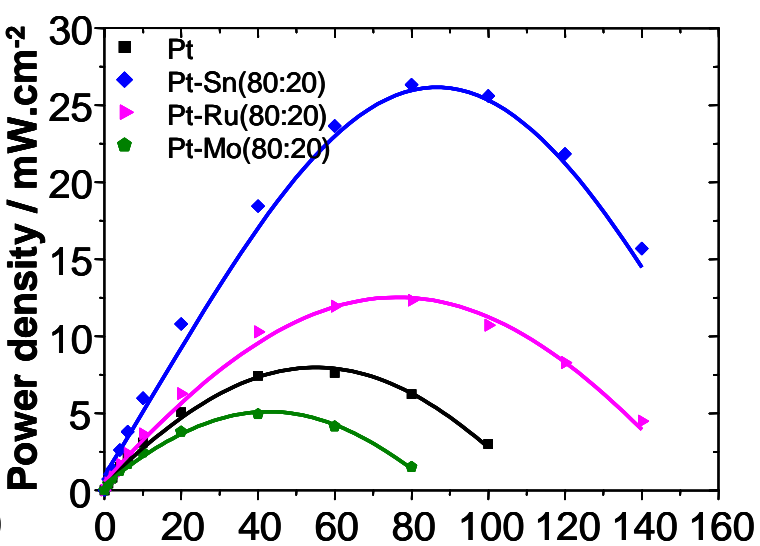

Current density / $\mathrm{mA} \mathrm{cm}^{-2}$

Power density curves

Figure 7: Fuel cell characteristics of a DEFC recorded at $110^{\circ} \mathrm{C}$. Influence of the nature of the bimetallic anodic catalyst (30\% loading). Anode catalyst : $1.5 \mathrm{mg} . \mathrm{cm}^{-2}$; Cathode catalyst : 2 mg.cm ${ }^{-2}$ (40\% Pt/XC72 E-TEK) ; Membrane : Nafion ${ }^{\circledR} 117$; Ethanol concentration : 1 M.

After C. Lamy et al, Chap.1, C. Bianchini et al. 


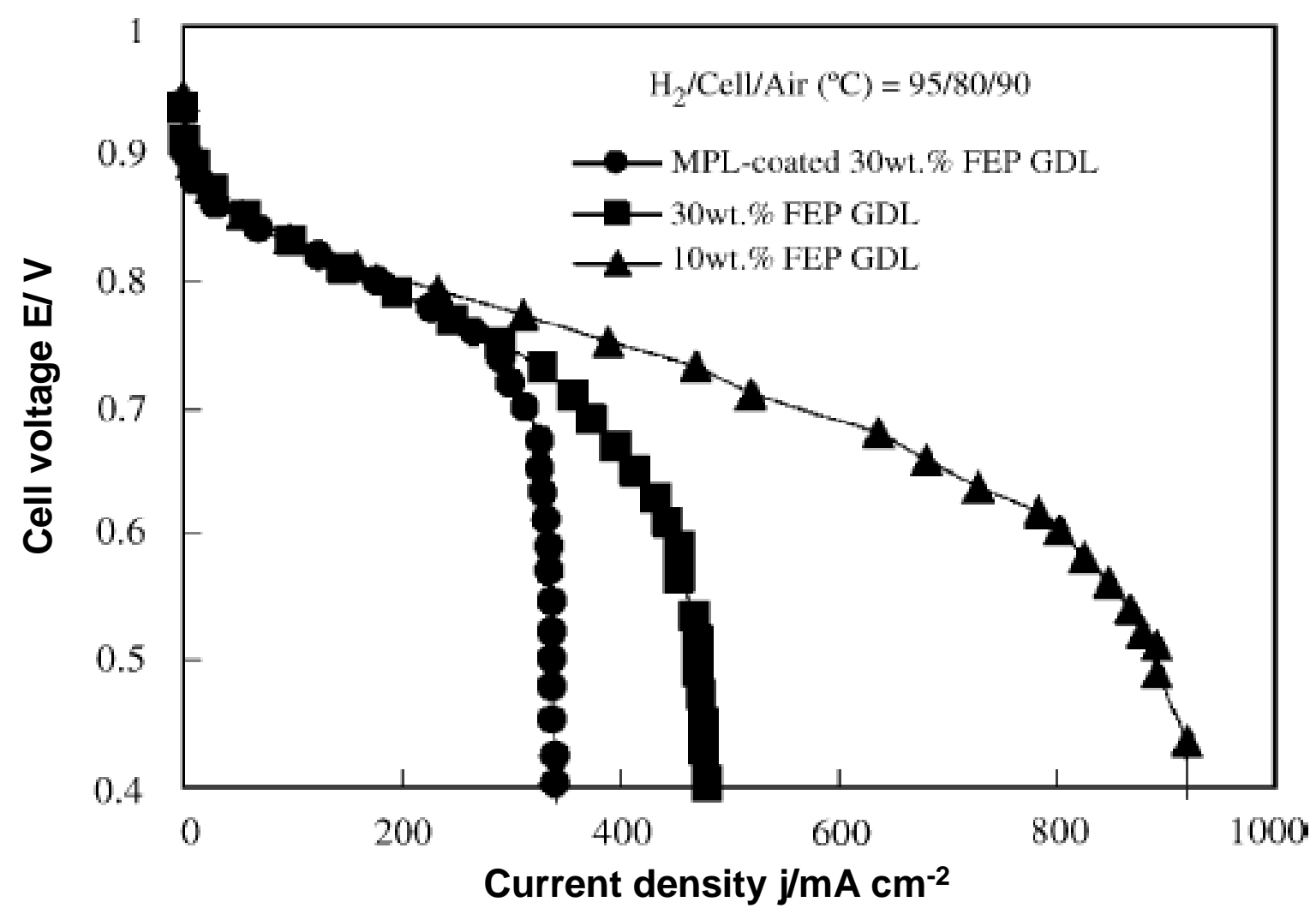

Figure 8: Cell voltage vs. current density curves for an $\mathrm{H}_{2}$ /air $\mathrm{FC}$ with MEAs using three different types of carbon cathode GDL $\left(80^{\circ} \mathrm{C}, 0.22 \mathrm{mg} \mathrm{cm}^{-2} \mathrm{Pt}\right.$ loading $)$ :

(•) microporous layer-coated and 30 wt.\% FEP-impregnated; (ロ) 30 wt.\% FEP-impregnated; (४ ) 10 wt.\% FEP-impregnated After C. Lim, C.Y. Wang, Electrochim. Acta 49 (2004) 4149-4156 
1

2
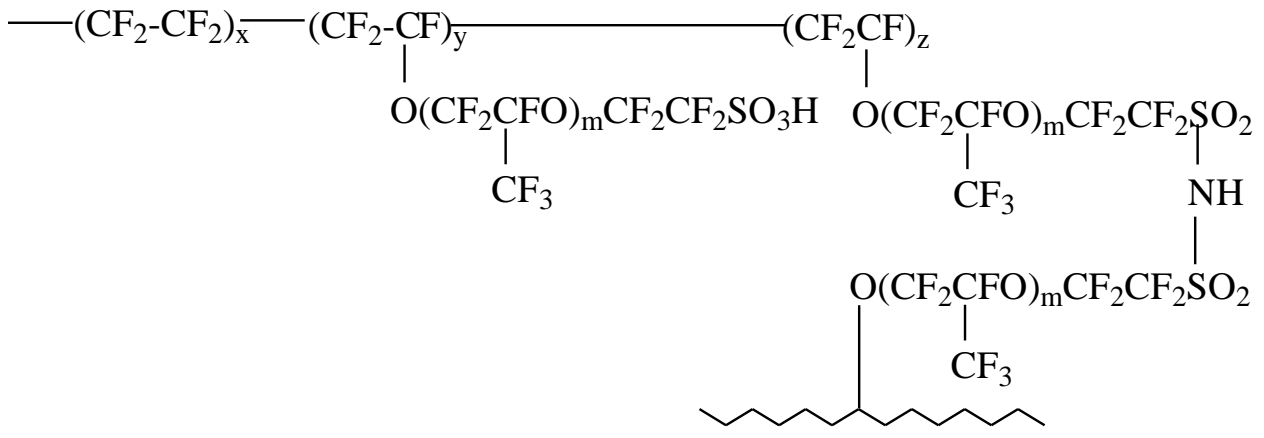

Figure 9: Acid form of sulfonimide-bridged perfluorosulfonic ionomer 


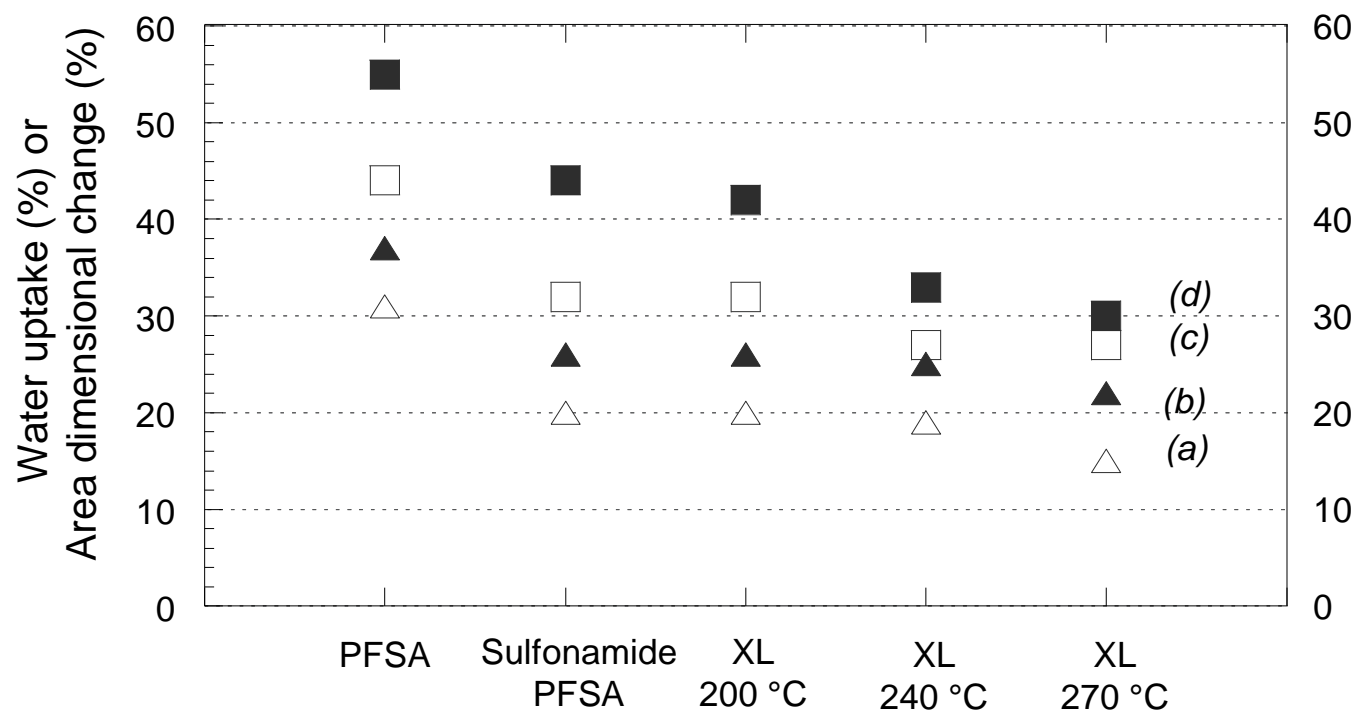

Figure 10: Water uptake $(\%)$ at $25^{\circ} \mathrm{C}(\triangle)$ and $80^{\circ} \mathrm{C}(\boldsymbol{\Delta})$, and area dimensional change $(\%)$ at $25^{\circ} \mathrm{C}(\square)$ and $80^{\circ} \mathrm{C}(\boldsymbol{\square})$ in reference PFSA membrane, non-cross-linked sulfonamide and cross-linked (XL) sulfonimide forms prepared by thermal treatment at 200,240 and $270^{\circ} \mathrm{C}$. 

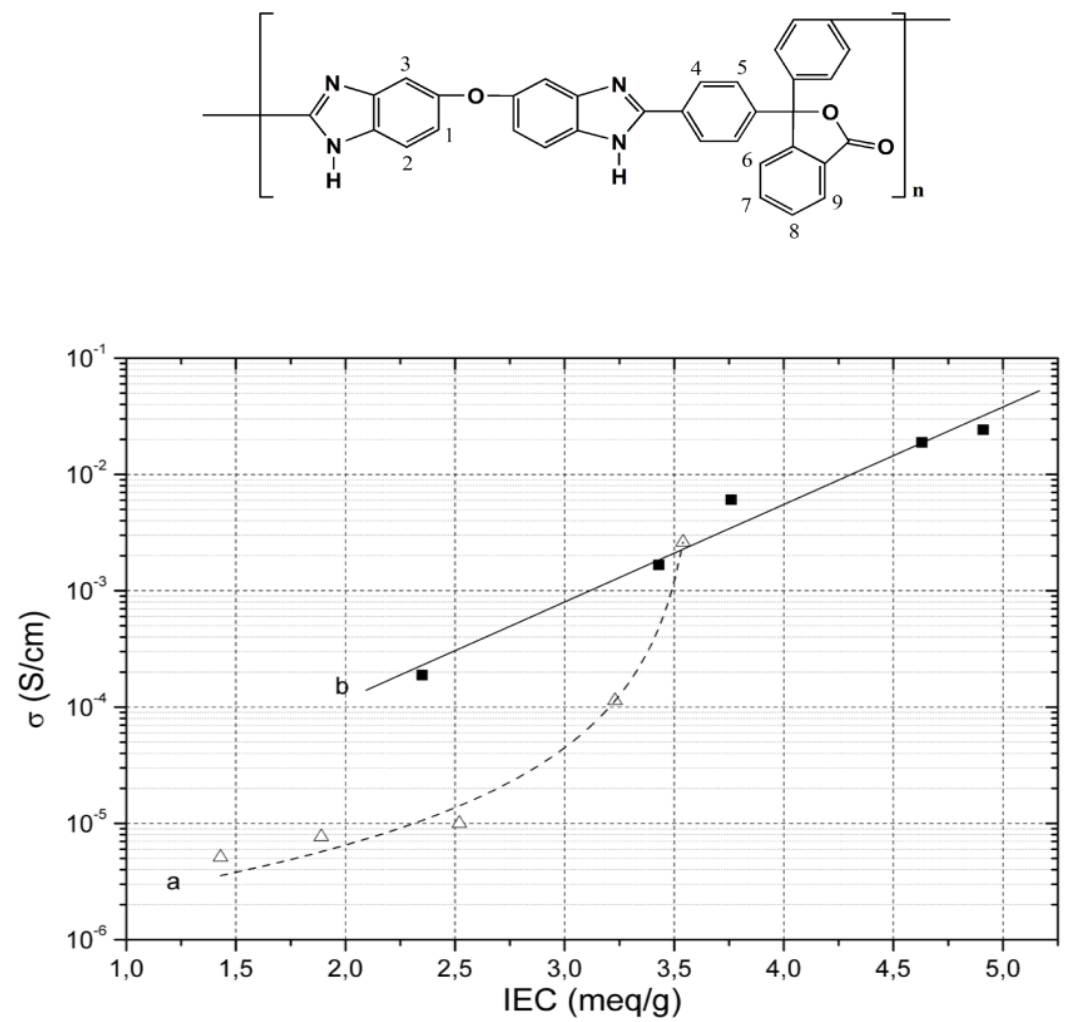

Figure 11: Conductivity of sPBI-OPh sulfonated in a) $96 \% \mathrm{H}_{2} \mathrm{SO}_{4}$ b) $30 \%$ oleum at $25^{\circ} \mathrm{C}$ and $100 \%$ relative humidity, as a function of the IEC of the sulfonated polymer. In a), sulfonation occurs preferentially on the benzyl rings adjacent to ether linkages; in b) sulfonation also occurs on the Cardo group. 


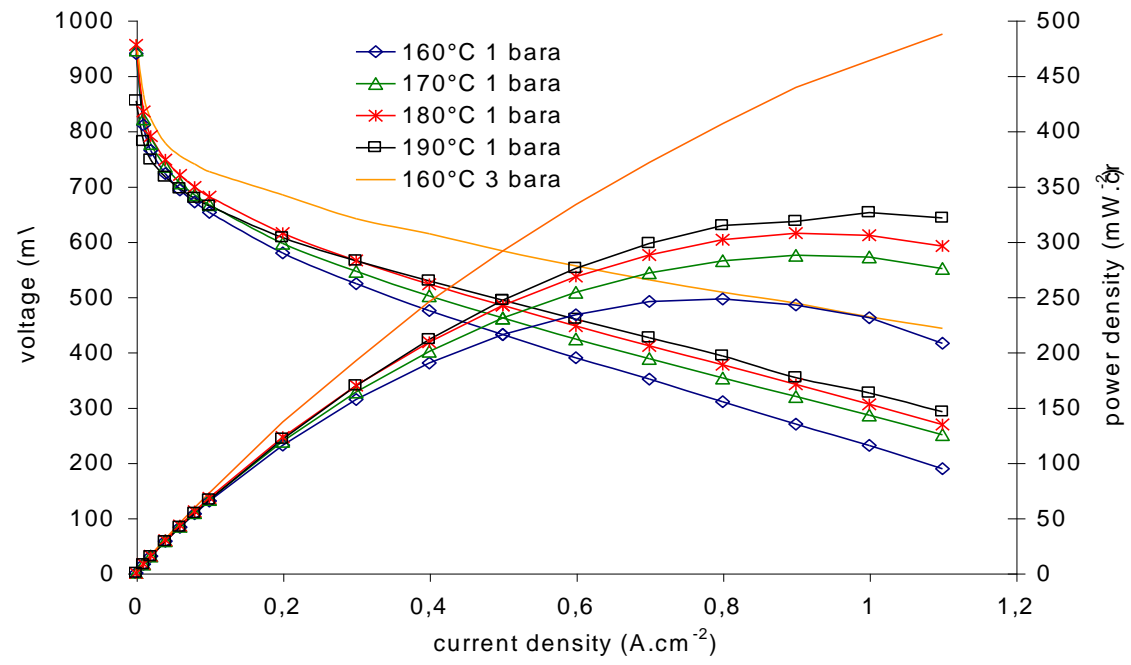

Figure 12: Cell voltage and power density as a function of current density (active surface area $45 \mathrm{~cm}^{2}$ ) of Celtec-V type MEAs based on PBI and poly(vinylphosphonic) acid, operated on hydrogen and air hydrated at $80 / 64^{\circ} \mathrm{C}$ respectively, under the temperature and pressure conditions shown (collaboration CNRS-ICGM - BASF Fuel Cell in FP6 Autobrane). 


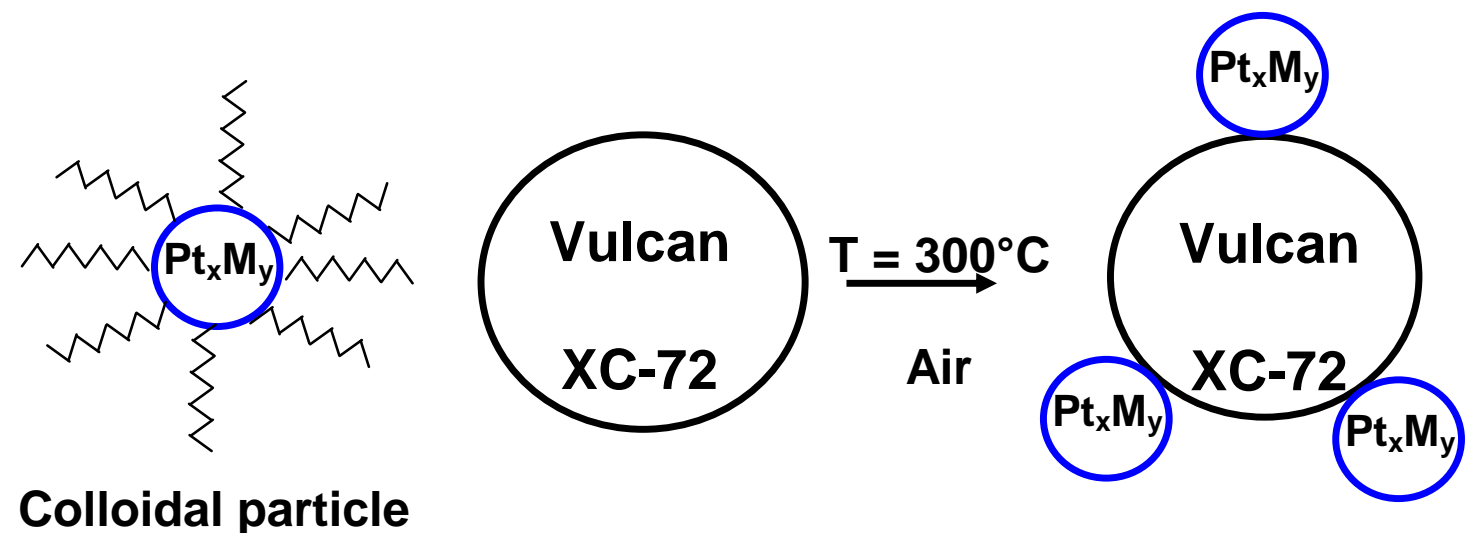

a) $\mathrm{Pt}_{\mathrm{x}} \mathrm{M}_{\mathrm{y}} / \mathrm{XC}-72$ catalysts
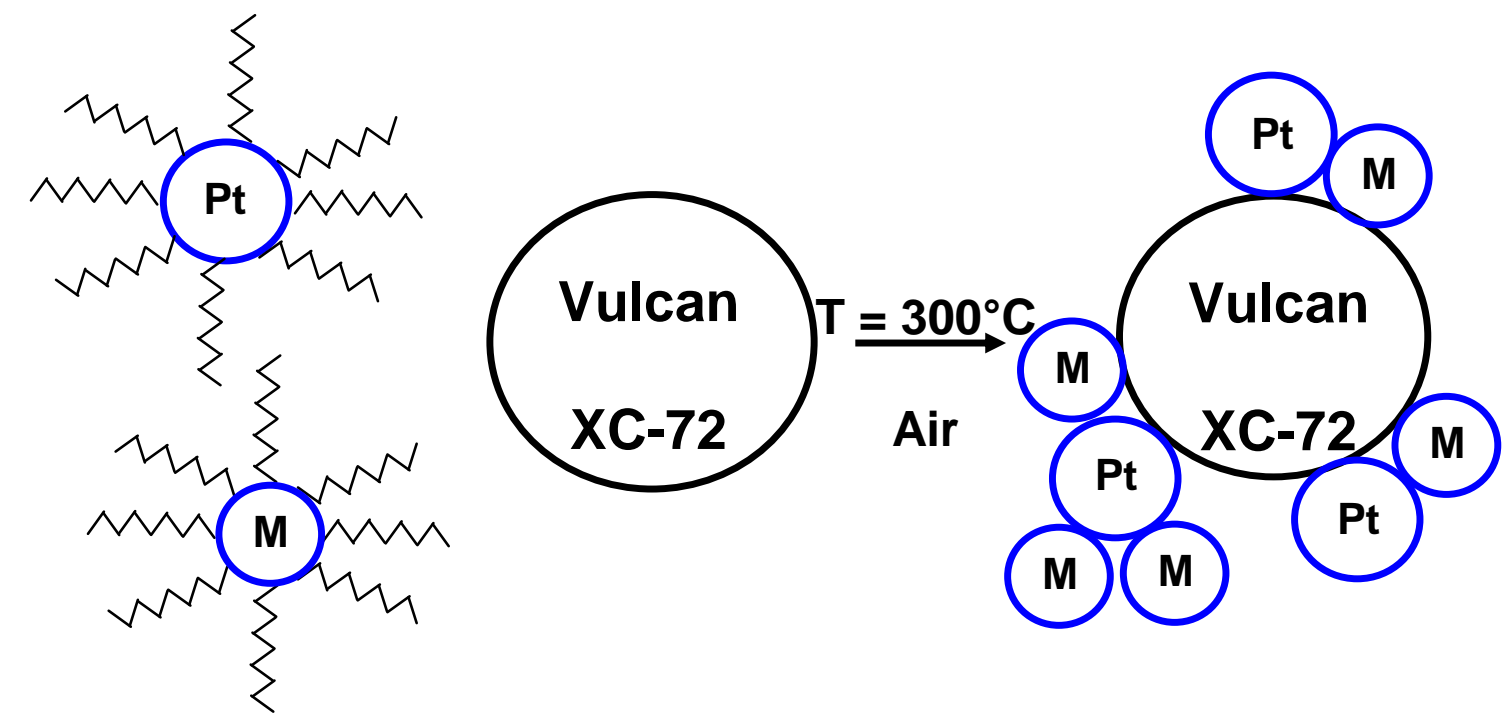

Colloidal particles

b) $\mathrm{Pt}_{\mathrm{x}}+\mathrm{M}_{\mathrm{y}} / \mathrm{XC}-72$ catalysts

Figure 13: Deposition of colloidal particles on a carbon powder. 


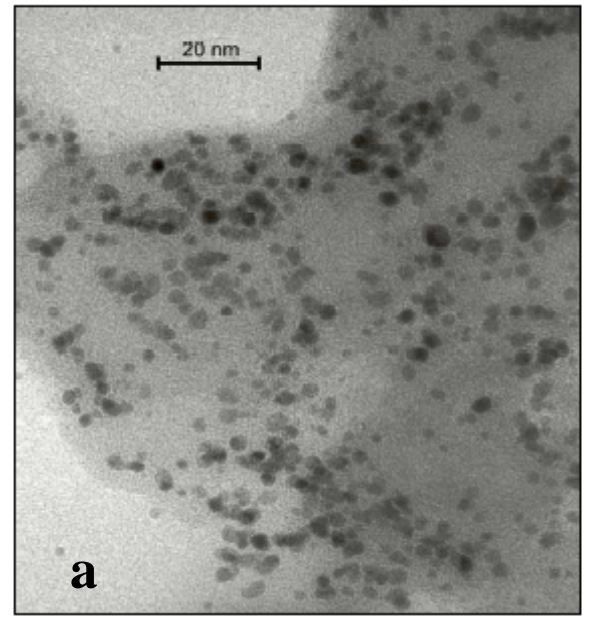

TEM image of a Vulcan supported $\mathrm{Pt} / \mathrm{XC72}$ catalyst

(with a metal loading of $30 \%$ ) prepared by the colloidal method

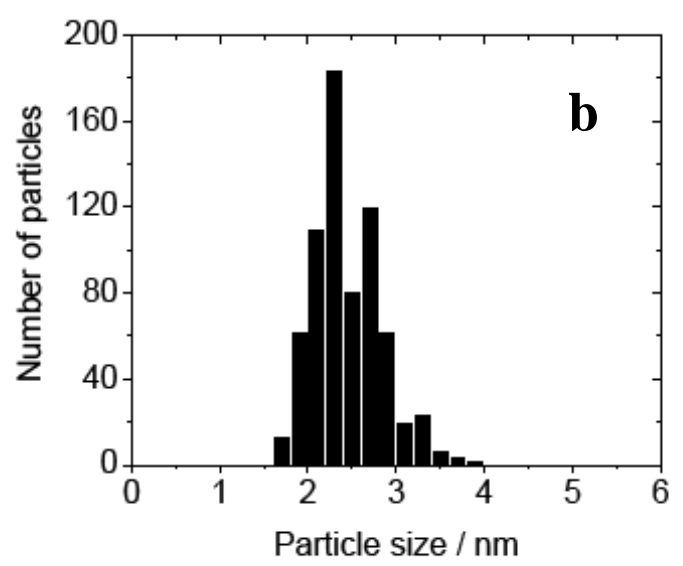

Particle size distribution of the corresponding Pt/XC72 catalyst (based on the observation of 678 particles)

Mean diameter : $2.4 \pm 0.4 \mathrm{~nm}$

Figure 14: Characterization of a Pt catalyst prepared by the colloidal method 


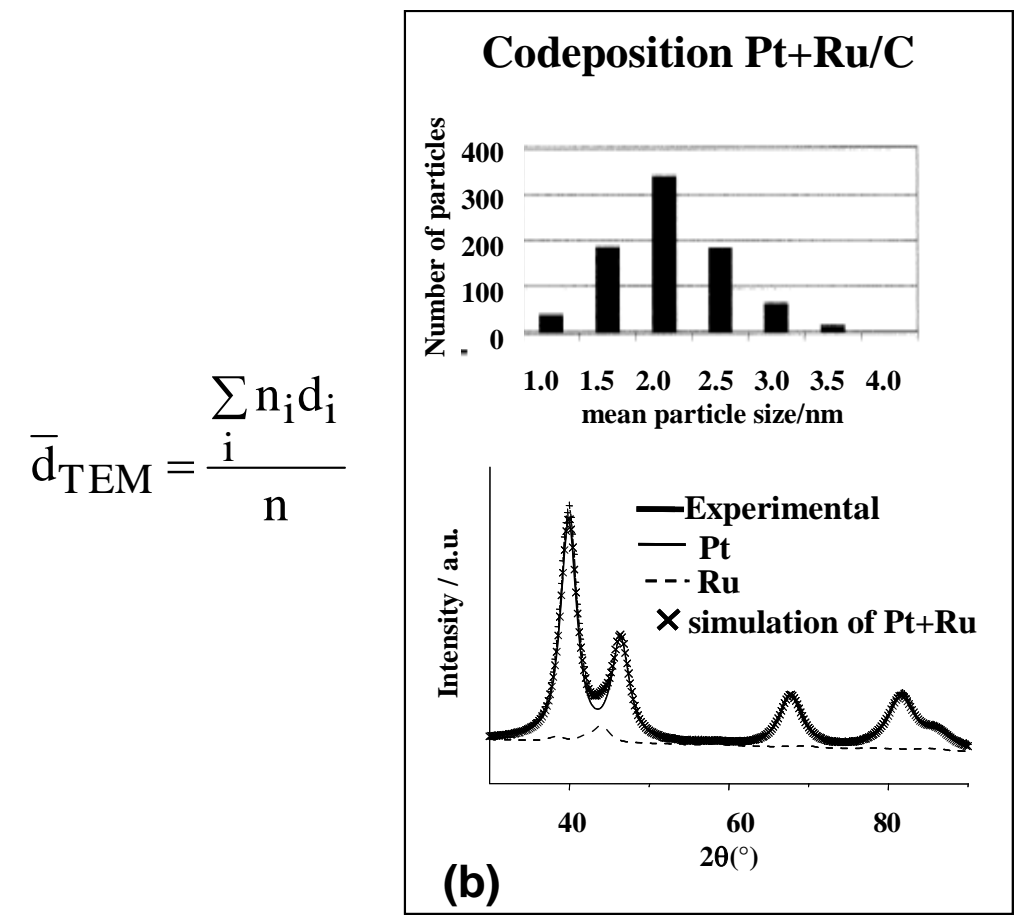

Figure 15: Characterization of a $\mathrm{Pt}_{0.8} \mathrm{Ru}_{0.2} / \mathrm{C}$ bimetallic catalyst prepared by the Bönnemann colloidal method: (a) co-reduced catalyst; 'b) co-deposited catalyst. 
1

2

3

4

5

6

7

8

9

10

11

12

13

14

15

16

17

18

19

20

21

22

23

24

25

26

27

28

29

30

31

32

33

34

35

36

37

38

39

40

41

42

43

44

45

46

47

48

49

50

51

52

53

54

55

56

57

58

59

60

61

62

63

64

65

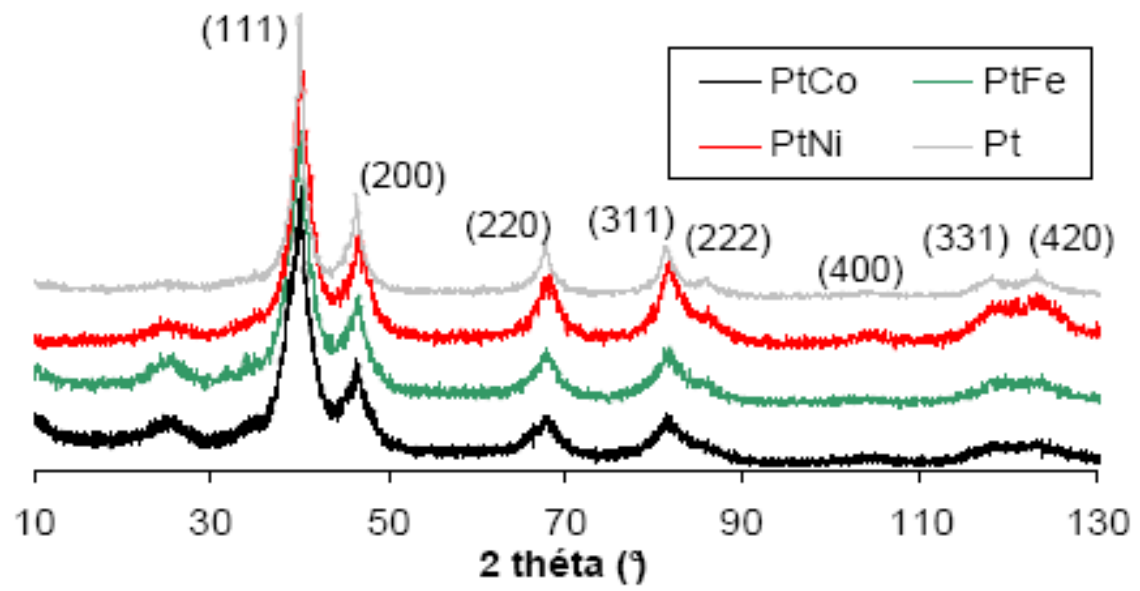

Figure 16: XRD patterns of different $\mathrm{PtM}(40 \mathrm{wt} \%) / \mathrm{XC} 72$ catalysts prepared by the Bönnemann method. 


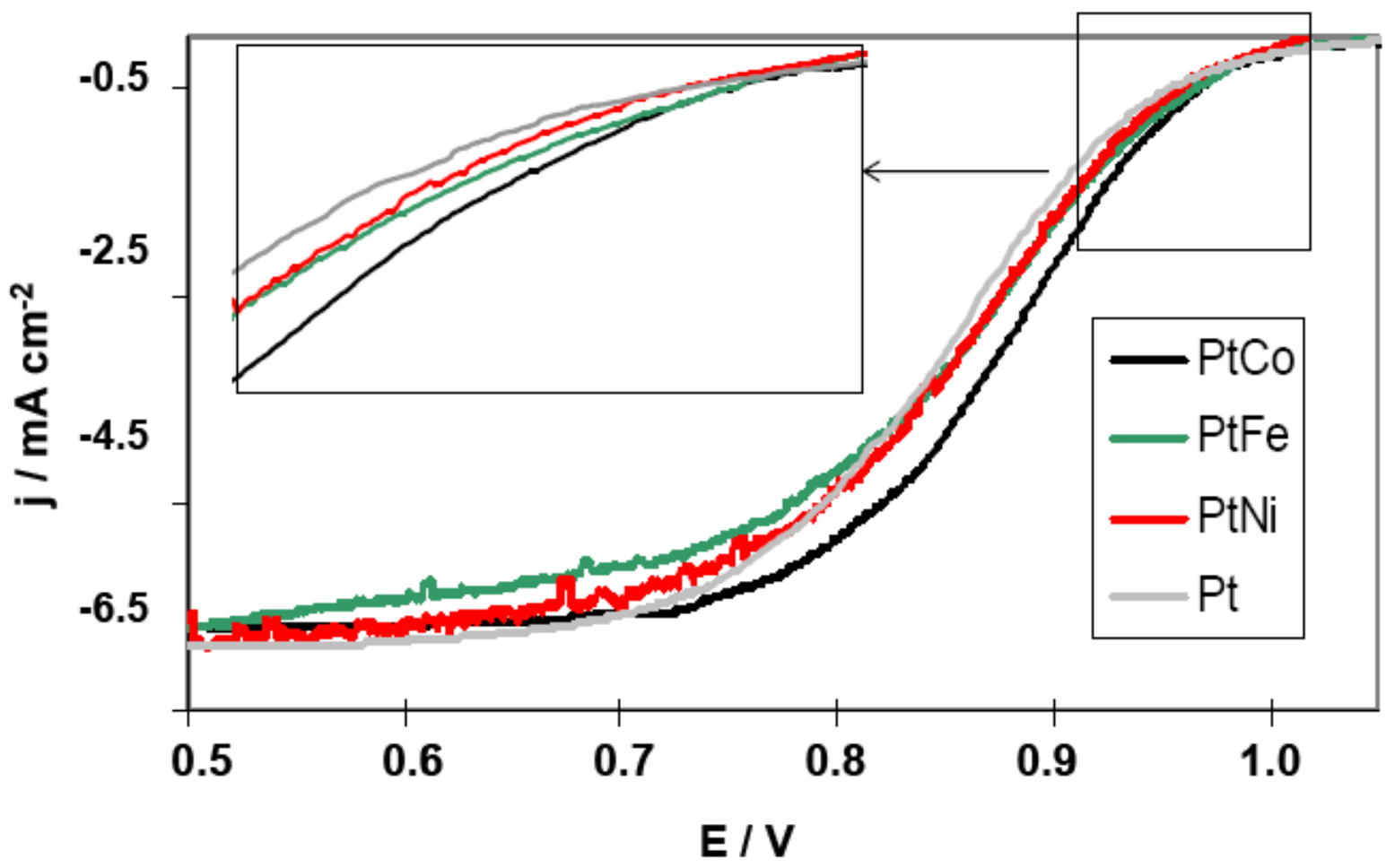

Figure 17: Voltammetric curves of the ORR at $\mathrm{Pt}_{3} \mathrm{M}(40 \mathrm{wt} \%) / \mathrm{C}$ binary catalysts $(\mathrm{M}=\mathrm{Co}, \mathrm{Fe}$, $\mathrm{Ni}$ ) in $\mathrm{O}_{2}$-saturated $\mathrm{H}_{2} \mathrm{SO}_{4}$ at $\mathrm{T}=20^{\circ} \mathrm{C}, \mathrm{v}=3 \mathrm{mV} \mathrm{s}^{-1}$ and $\Omega=2500 \mathrm{rpm}$. 

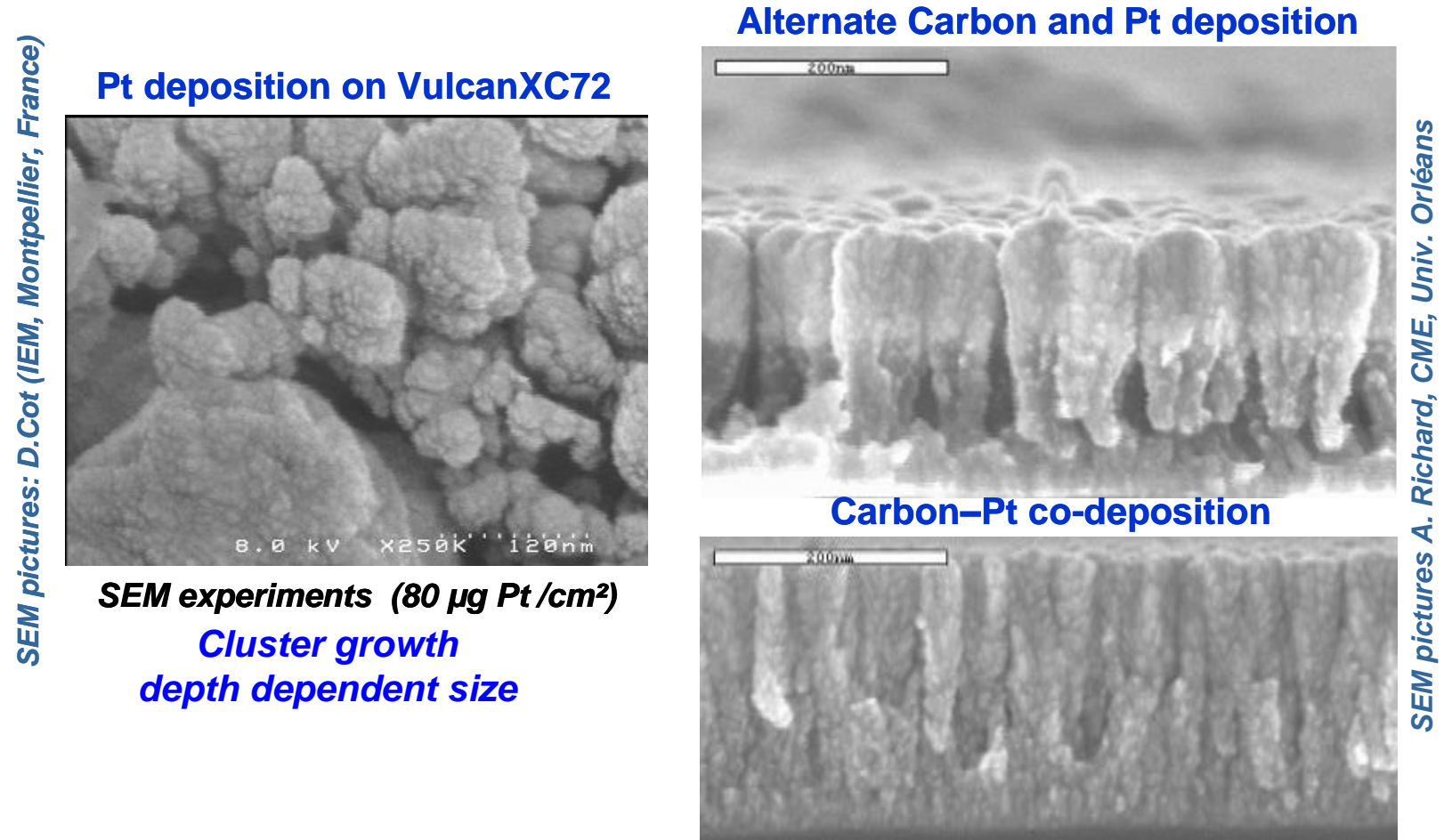

Figure 18: PEMFC electrode deposition on a carbon diffusion layer

After H. Rabat, P. Brault, Plasma sputtering deposition of PEMFC porous carbon platinum electrodes, Fuel Cells 8, 81-86 (2008)

H. Rabat, C. Andreazza, P. Brault, A. Caillard, F. Béguin, C. Charles, R. Boswell, Carbon /platinum nanotextured films produced by plasma sputtering, Carbon 47, 209-214 (2009) 


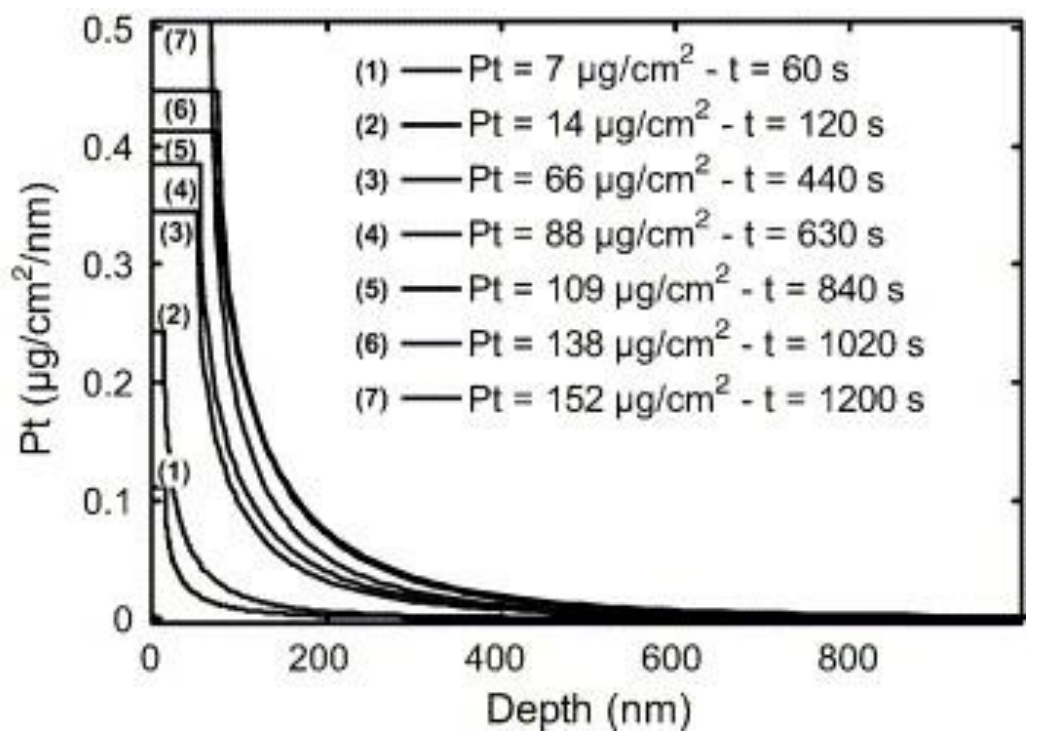

Figure 19: Depth distribution of platinum inside the C/Pt electrode (as measured by RBS) 


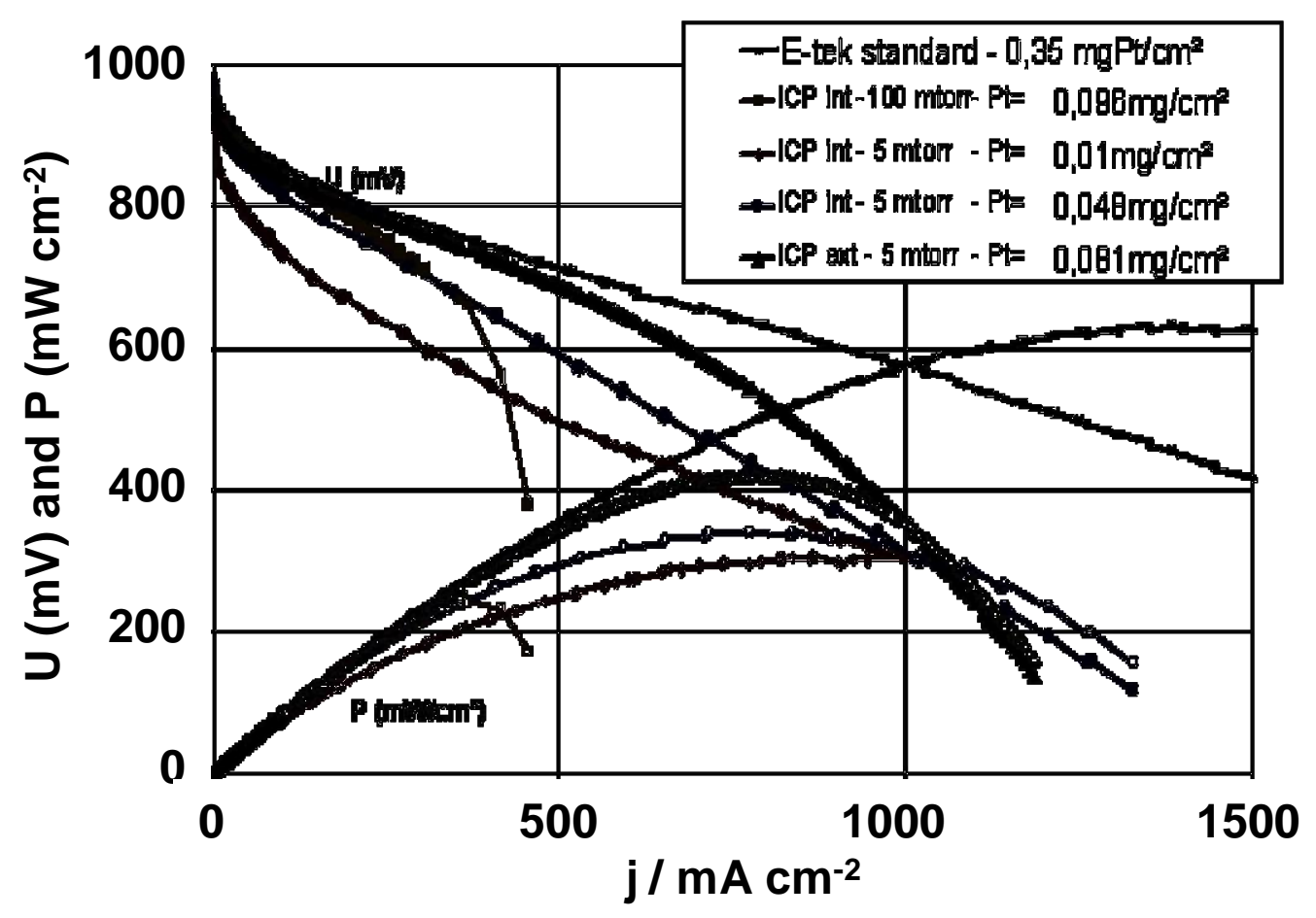

Figure 20: Electrical performances of several PEMFC with plasma cathodes made with different $\mathrm{Pt}$ loadings; $\mathrm{H}_{2}$ and $\mathrm{O}_{2}$ at 4 bars; cell at $80^{\circ} \mathrm{C}$. 


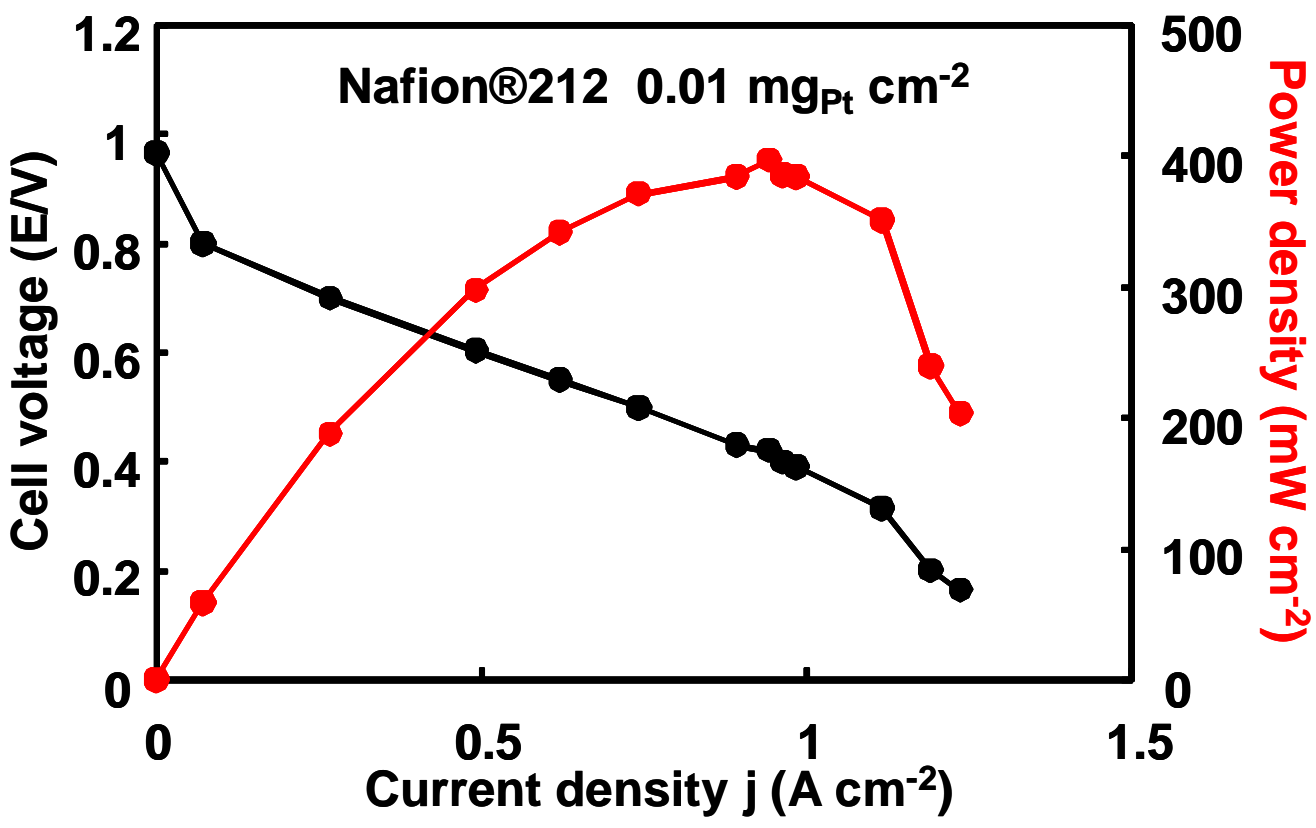

Figure 21: Fuel cell tests of a C-Pt co-deposited on an E-Tek diffusion layer [81]. 


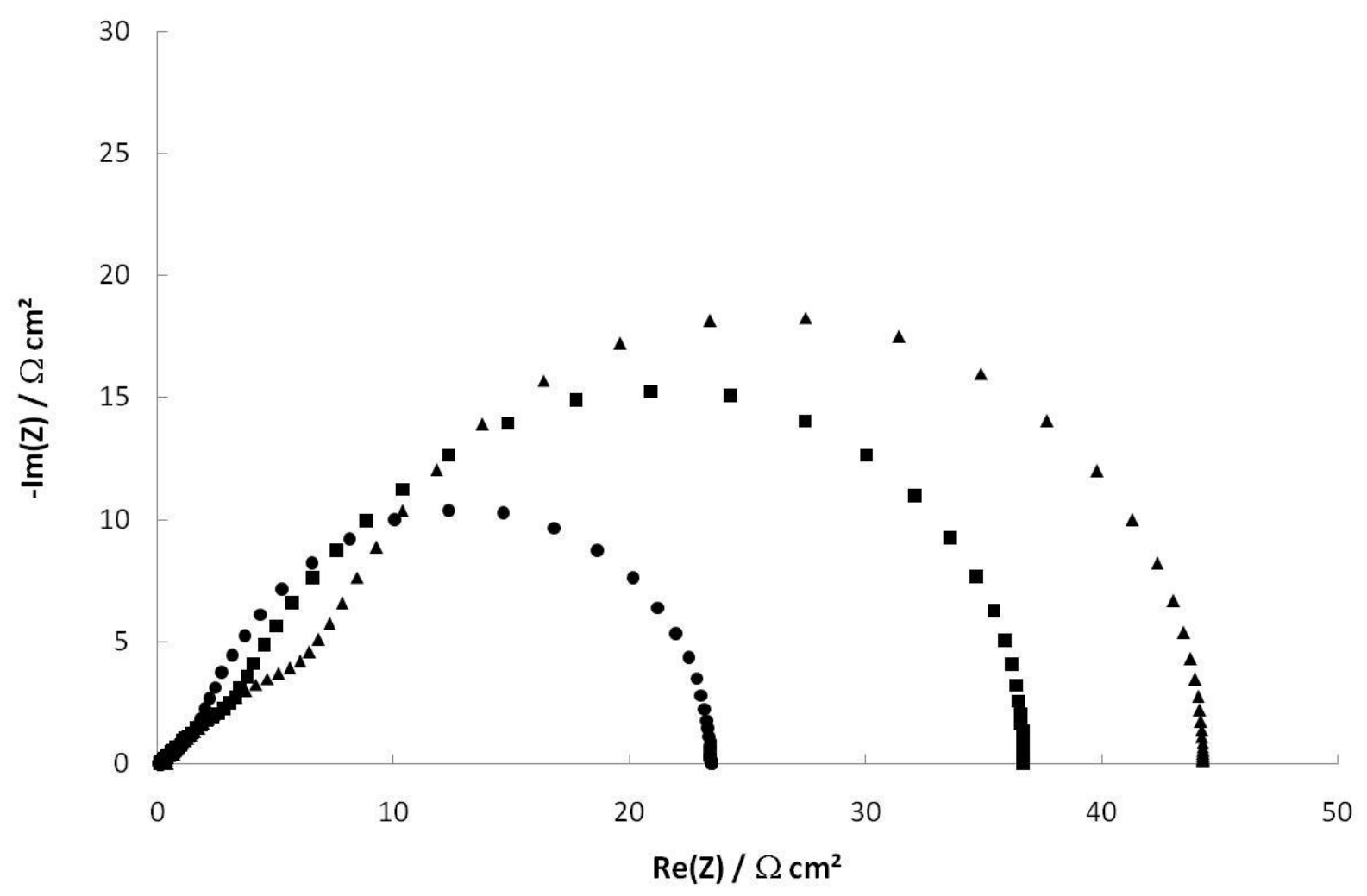

Figure 22: Simulated impedance diagrams for a catalyst layer $(\eta=0.4 \mathrm{~V}):(\boldsymbol{O}) \gamma=50 \mathrm{~cm}^{2} \mathrm{~cm}^{-2}$ and $\mathrm{L}=5 \mu \mathrm{m} ;(\boldsymbol{\square}) \gamma=50 \mathrm{~cm}^{2} \mathrm{~cm}^{-2}$ and $\mathrm{L}=10 \mu \mathrm{m} ;(\boldsymbol{\Delta}) \gamma=100 \mathrm{~cm}^{2} \mathrm{~cm}^{-2}$ and $\mathrm{L}=20 \mu \mathrm{m}$. 


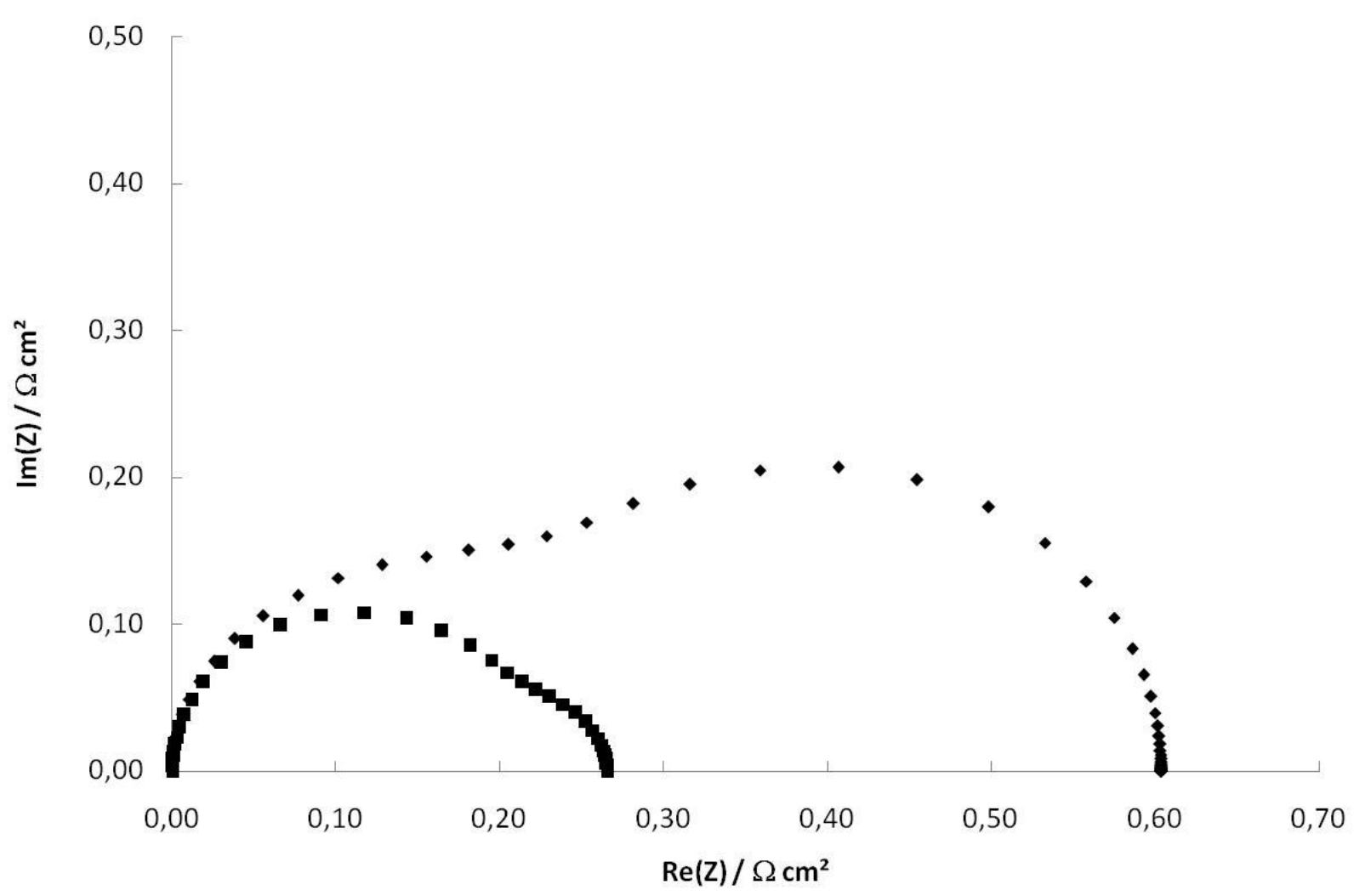

Figure 23: Simulated impedance diagrams for a $\operatorname{GDE}\left(\mathrm{j}=1 \mathrm{~A} \mathrm{~cm}^{-2}\right.$ and $\left.\mathrm{L}^{\mathrm{GDL}}=500 \mu \mathrm{m}\right)$ :

$$
\varepsilon^{\mathrm{GDL}}=40 \% ;(\diamond) \varepsilon^{\mathrm{GDL}}=20 \%
$$




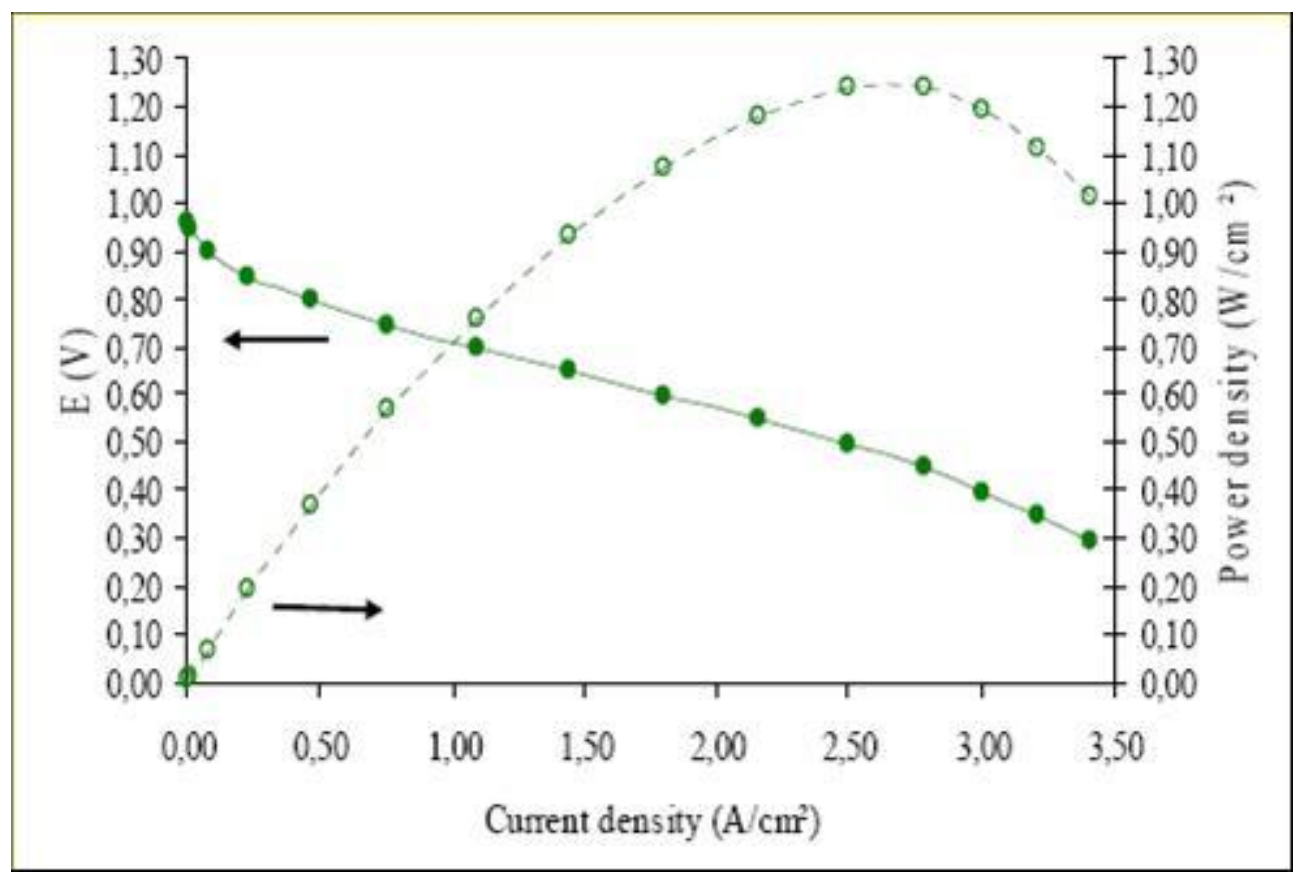

Figure 24: Performance of a MEA fabricated with Pt/C catalysts synthesized by the colloidal route. Membrane: Nafion 112; Symmetric electrodes : $0.35 \mathrm{mg}_{\mathrm{Pt}} \mathrm{cm}^{-2}$; Pt loading 40 wt. \% $/ \mathrm{C}\left(\mathrm{T}_{\text {cell }}=\mathrm{T}_{\text {huma }}=70^{\circ} \mathrm{C}, \mathrm{T}_{\text {humc }}=25^{\circ} \mathrm{C}, \mathrm{H}_{2}\right.$ flow $=600 \mathrm{~mL} \mathrm{~min}^{-1}, \mathrm{O}_{2}$ flow $=300 \mathrm{~mL} \mathrm{~min}^{-1}$, $\mathrm{P}_{\mathrm{H}_{2}}=\mathrm{P}_{\mathrm{O}_{2}}=3$ bar). 


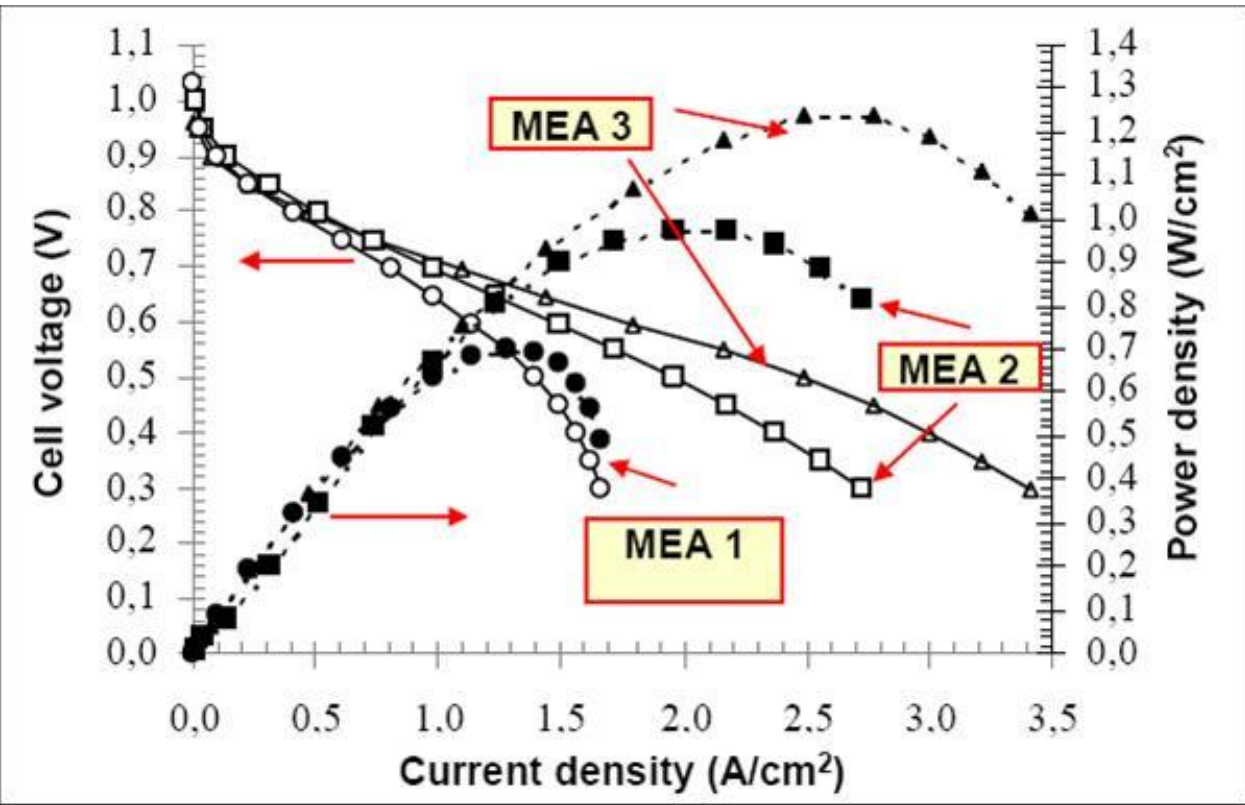

Figure 25: Comparison between commercial and homemade MEAs. MEA 1: homemade anode via platinum plasma sputtering + homemade cathode via the colloidal route $(0.45$ $\mathrm{mg}_{\mathrm{Pt}} \mathrm{cm}^{-2}$ total loading); MEA 2 : commercial MEA from FCS $\left(1.2 \mathrm{mg}_{\mathrm{Pt}_{\mathrm{t}}} \mathrm{cm}^{-2}\right.$ total loading); MEA 3 : homemade electrodes via the colloidal route $\left(0.7 \mathrm{mg}_{\mathrm{Pt}_{\mathrm{t}}} \mathrm{cm}^{-2}\right.$ total loading). $\mathrm{T}_{\text {cell }}=85^{\circ} \mathrm{C} ; \mathrm{T}_{\text {huma }}=80^{\circ} \mathrm{C}, \mathrm{T}_{\text {humc }}=35^{\circ} \mathrm{C}, \mathrm{H}_{2}$ flow $=600 \mathrm{~mL} \mathrm{~min}^{-1}, \mathrm{O}_{2}$ flow $=300$ $\mathrm{mL} \min ^{-1}, \mathrm{P}_{\mathrm{H}_{2}}=\mathrm{P}_{\mathrm{O}_{2}}=2.3$ bar 


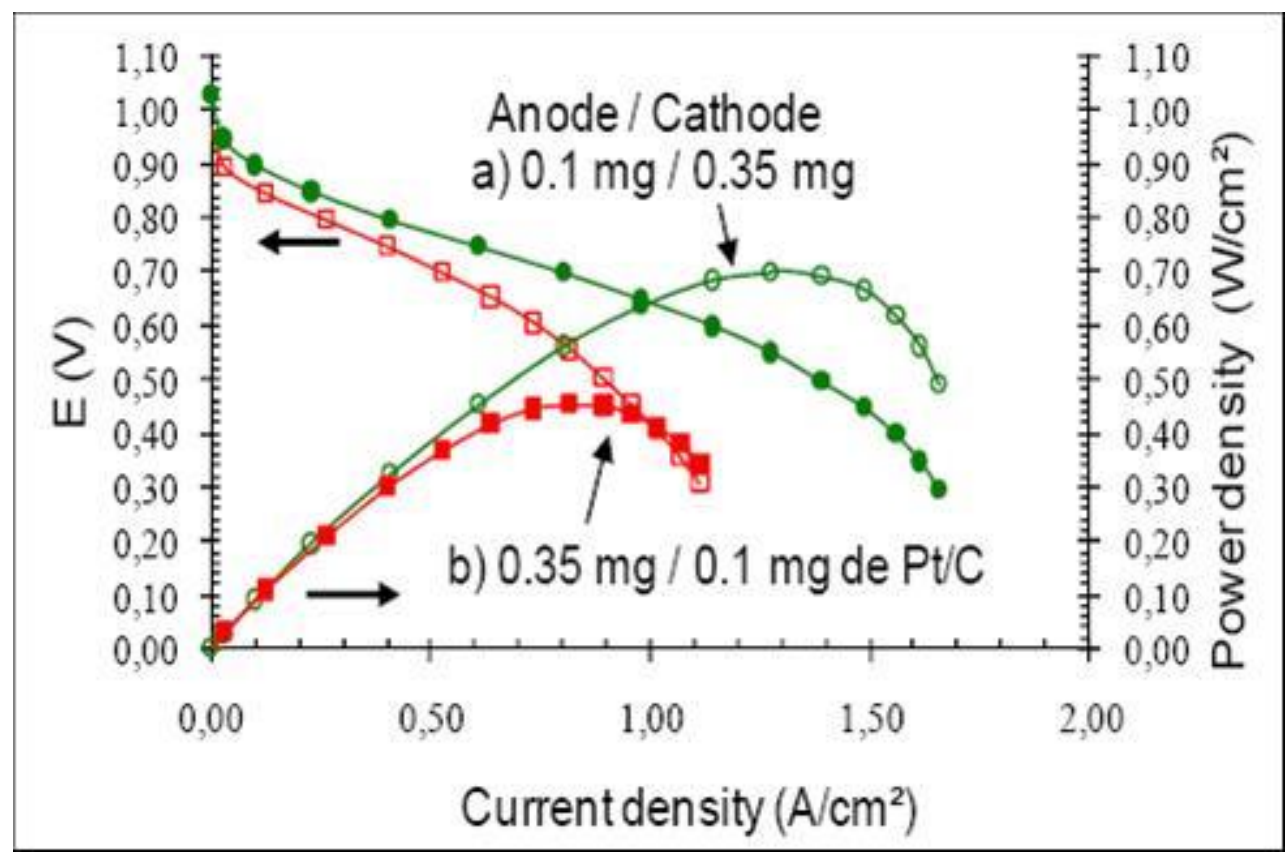

Figure 26: Performance of MEAs fabricated with Pt40wt.\%/C electrodes synthesized by plasma sputtering $\left(0.1 \mathrm{mg}_{\mathrm{Pt}} \mathrm{cm}^{-2}\right)$ or by the colloidal route $\left(0.35 \mathrm{mg}_{\mathrm{Pt}} \mathrm{cm}^{-2}\right)$ and a Nafion ${ }^{\circledR}$ 112 membrane. $\left(\mathrm{T}_{\text {cell }}=\mathrm{T}_{\text {huma }}=70^{\circ} \mathrm{C}, \mathrm{T}_{\text {humc }}=25^{\circ} \mathrm{C}, \mathrm{H}_{2}\right.$ flow $=600 \mathrm{~mL} \mathrm{~min}{ }^{-1}, \mathrm{O}_{2}$ flow $=$ $300 \mathrm{~mL} \mathrm{~min}{ }^{-1}, \mathrm{P}_{\mathrm{H}_{2}}=\mathrm{P}_{\mathrm{O}_{2}}=3$ bar). 